2014

THE EFFECT OF ANNEALING ON AMORPHOUS SILICON BASED

SOLAR PHOTOVOLTAIC THERMAL SYSTEM (PV/T) AND APPROPRIATE GLOBAL DISPATCH STRATEGIES

Joseph Rozario

Michigan Technological University

Follow this and additional works at: https://digitalcommons.mtu.edu/etds

Part of the Electrical and Computer Engineering Commons, and the Oil, Gas, and Energy Commons Copyright 2014 Joseph Rozario

Recommended Citation

Rozario, Joseph, "THE EFFECT OF ANNEALING ON AMORPHOUS SILICON BASED SOLAR PHOTOVOLTAIC THERMAL SYSTEM (PV/T) AND APPROPRIATE GLOBAL DISPATCH STRATEGIES", Master's Thesis, Michigan Technological University, 2014.

https://doi.org/10.37099/mtu.dc.etds/837

Follow this and additional works at: https://digitalcommons.mtu.edu/etds

Part of the Electrical and Computer Engineering Commons, and the Oil, Gas, and Energy Commons 


\title{
THE EFFECT OF ANNEALING ON AMORPHOUS SILICON BASED SOLAR PHOTOVOLTAIC THERMAL SYSTEM (PV/T) AND APPROPRIATE GLOBAL DISPATCH STRATEGIES
}

\author{
By
}

Joseph Rozario

A thesis submitted in partial fulfillment of the requirements for the degree of MASTER OF SCIENCE

In Electrical Engineering

MICHIGAN TECHNOLOGICAL UNIVERSITY

2014

Copyright $@$ Joseph Rozario, 2014. 

This thesis has been approved in partial fulfillment for the requirements for the Degree of MASTER OF SCIENCE in Electrical Engineering.

Department of Electrical and Computer Engineering

Thesis Advisor: $\quad$ Dr. Joshua M. Pearce

Committee Member: $\quad$ Dr. Paul L. Bergstrom

Committee Member: Dr. Yun Hang Hu

Department Chair: $\quad$ Dr. Daniel R. Fuhrman 



\section{CONTENTS}

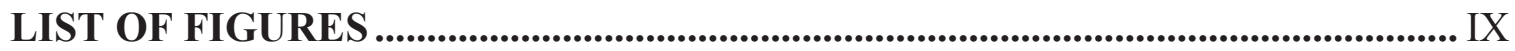

LIST OF TABLES .............................................................................................................. XIII

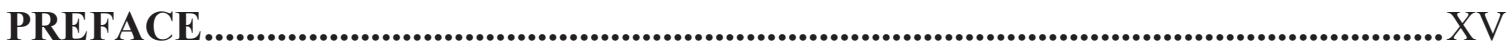

ACKNOWLEDGEMENTS .................................................................................. XVII

LIST OF ABBREVIATIONS ............................................................................ XIX

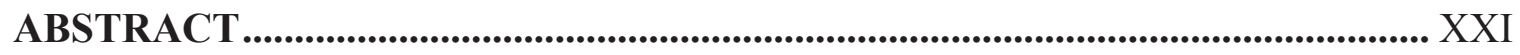

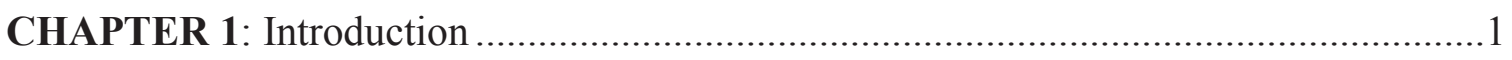

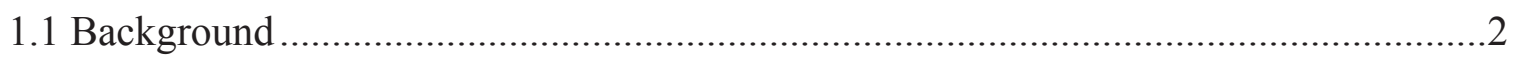

1.2 Hydrogenated Amorphous Silicon in Photovoltaic Thermal System ..........................

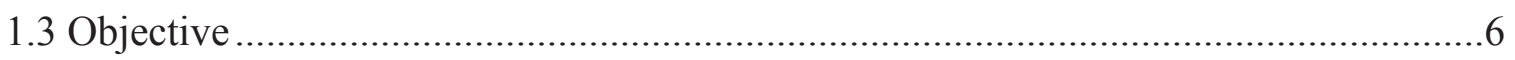

1.4 Device Structure and Degradation Characteristics ..............................................

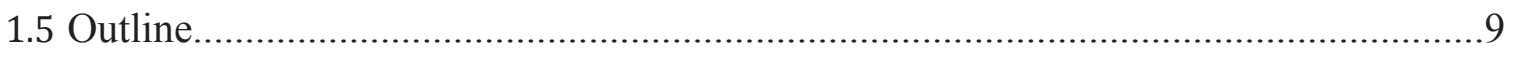

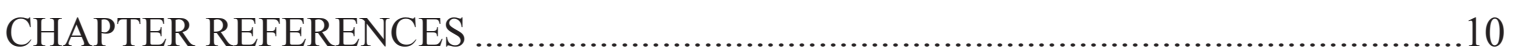

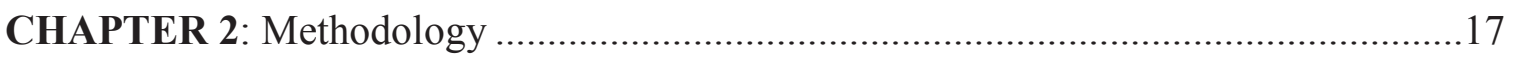

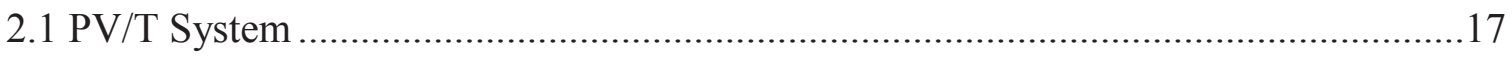

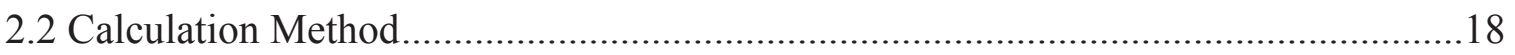

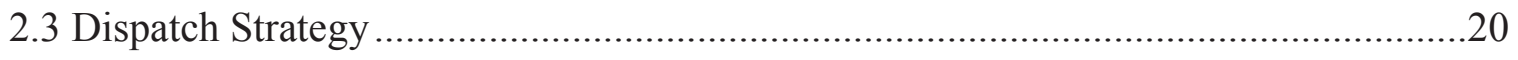

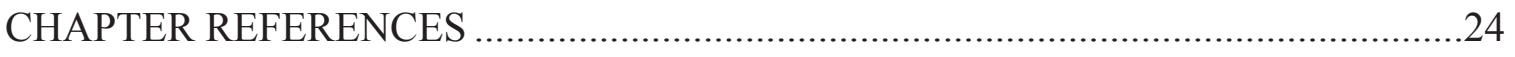

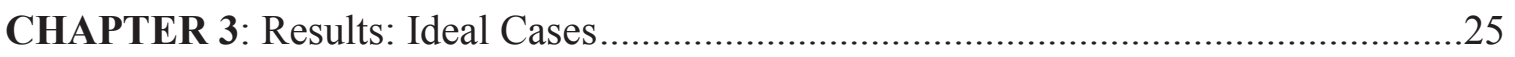

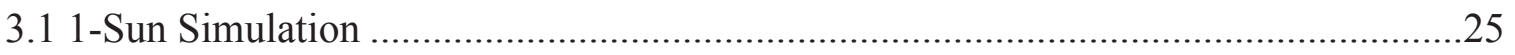


3.2 Simulation Based on Real Time Hourly Solar Irradiance Data ..............................28

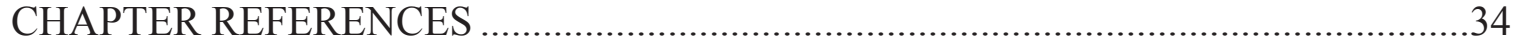

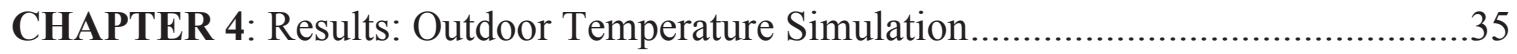

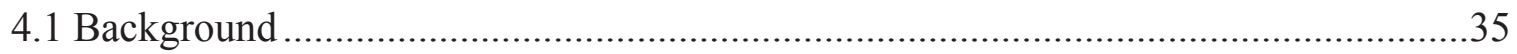

4.1.1 Degradation Associated Parameters ......................................................35

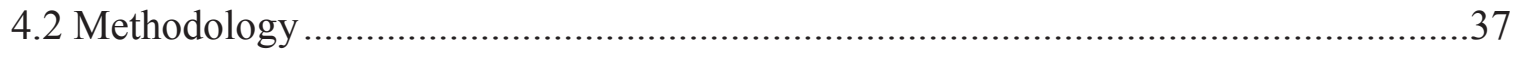

4.2.1 Global Expansion and Simulation Mechanism Updates.............................37

4.2.2 Association of Temperature Data for Selected Locations ...........................38

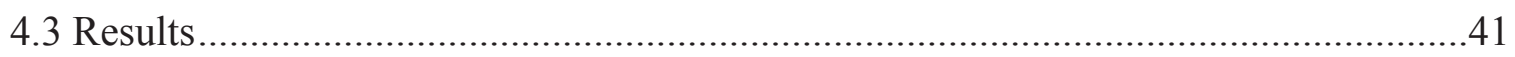

4.3.1 Simulation at Sustained Operating Temperature ....................................41

4.3.2 Sensitivity and Outdoor Operating Conditions ......................................44

4.3.3 Simulation at Outdoor Operating Conditions ......................................45

4.3.4 Appropriate Dispatch Strategy ..........................................................51

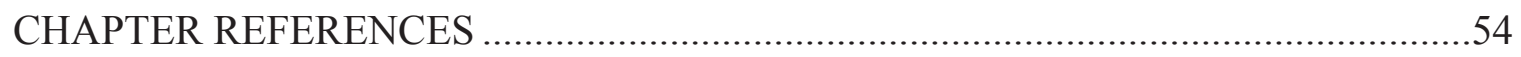

CHAPTER 5: Discussion, Future Work and Conclusions .........................................57

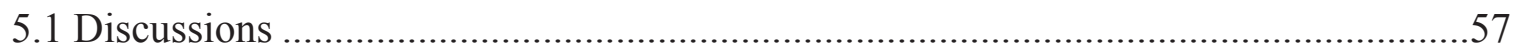

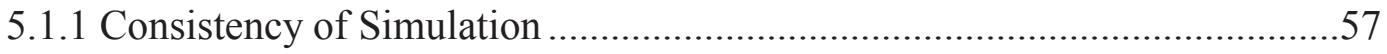

5.1.2 Limitations of the Simulation Method .....................................................58

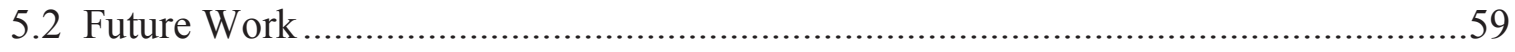

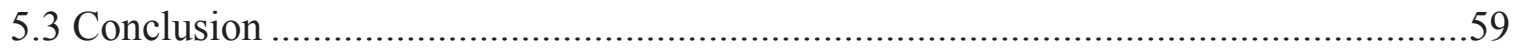

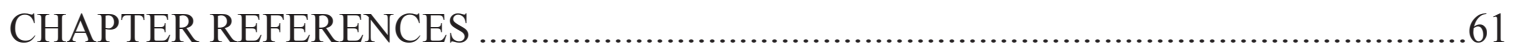




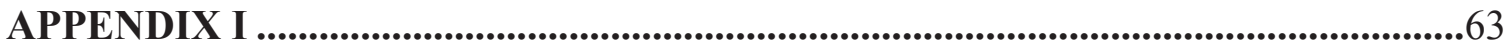

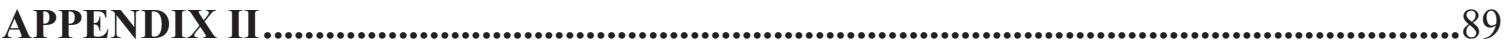





\section{LIST OF FIGURES}

Fig. 1.1 Temperature Vs efficiency plot for crystalline and amorphous silicon PV cells

Fig. 1.2 Composition and structure of the a-Si:H solar photovoltaic cell (device with 630 nm i-layer thickness considered as reference model)

Fig. 1.3 A normalized temperature series of 25, 50 and $901 \mathrm{C}$ degradation under 1 sun for a PV cell with an i-layer thickness of $630 \mathrm{~nm}$

Fig. 1.4 Comparison of the same $630 \mathrm{~nm}$ i-layer thick a-Si:H PV cell degraded at $501 \mathrm{C}$ under 1 sun (Normal Degradation) to results obtained for degradation at $501 \mathrm{C}$ under 1 sun coupled with spike annealing at 100 1C on a 12 h cycle for 192 h (Spike Annealing) 8

Fig. 2.1 Schematic of a-Si:H-based PVT system .17

Fig. 2.2 Experimental data showing degenerated steady state obtained at temperatures 25 ${ }^{\circ} \mathrm{C}, 50{ }^{\circ} \mathrm{C}$, and $90{ }^{\circ} \mathrm{C}$ respectively for a-Si:H PV cell active layer thickness of $630 \mathrm{~nm}$ under 1 sun (source: Pathak et. al.) [44] and exponential fits using equation (2.3).

Fig. 2.3 Average hourly solar irradiance for the four cities for whole year (February 1st, 2012 - January 31st, 2013) .23

Fig. 3.1 Dispatch strategy Case-III: annealing once every other day, for the operating temperatures. a) $25{ }^{\circ} \mathrm{C}$, b) $50{ }^{\circ} \mathrm{C}$, and c) $90{ }^{\circ} \mathrm{C}$ at 1 sun .26

Fig. 3.2 Dispatch strategies consisting of Case-III: annealing once every day, under 1 sun, a) $50{ }^{\circ} \mathrm{C}$ degradation and b) $90{ }^{\circ} \mathrm{C}$ degradation. Dispatch Strategy Case-V: annealing twice every day, under 1 sun, c) $50{ }^{\circ} \mathrm{C}$ and d) $90{ }^{\circ} \mathrm{C}$ degradation. Dispatch Strategy CaseVI: annealing three times every day, under 1 sun, e) $50{ }^{\circ} \mathrm{C}$ and f) Dispatch Strategy Case$\mathrm{V}$; annealing three times every day, under 1 sun, $90{ }^{\circ} \mathrm{C}$ degradation .27 
Fig. 3.3 Hourly maximum output power for different dispatch strategies under 1 sun (operating temperature $90{ }^{\circ} \mathrm{C}$ ) .28

Fig. 3.4 Average hourly power generation in San Antonio for different case studies. Right $\mathrm{Y}$-axis shows average hourly solar irradiance .....

Fig. 3.5 Total energy generation (at operating temperature $25{ }^{\circ} \mathrm{C}, 50{ }^{\circ} \mathrm{C}$, and $90{ }^{\circ} \mathrm{C}$ under 1 sun) over a time period of 8784 hours as a function of the number of anneals per day

Fig. 3.6 Total energy generation under normal sun at operating temperature for a) $25{ }^{\circ} \mathrm{C}$, b) $50{ }^{\circ} \mathrm{C}$, and c) $90{ }^{\circ} \mathrm{C}$ for the four cities over a year with change in number of anneals per day. 30

Fig. 4.1 Degradation associated parameter $k_{d s s}$ against temperature .............................36

Fig. 4.2 Degradation associated parameter $u_{d s s}$ against temperature 37

Fig 4.3 Average hourly solar irradiation per day for the four cities .40

Fig. 4.4 Average hourly temperature readings per day for the four cities

Fig. 4.5 Total electrical energy generation over a year under different annealing conditions in Anchorage, $\mathrm{AK}$ at sustained operating temperatures. .41

Fig. 4.6 Total electrical energy generation over a year under different annealing conditions in Casa Grande, AZ at sustained operating temperatures

Fig. 4.7 Total electrical energy generation over a year under different annealing conditions in Apalachicola, FL at sustained operating temperatures

Fig. 4.8 Total electrical energy generation over a year under different annealing conditions in Aspen, $\mathrm{CO}$ at sustained operating temperatures

Fig. 4.9 Maximum electrical energy generation (obtained for annealing one time every day) over a year in the four cities at sustained operating temperatures .43 
Fig. 4.10 Sensitivity study with different outdoor operating conditions

Fig. 4.11 Total electrical energy generation over a year under different annealing cycles in Anchorage, $\mathrm{AK}$ at outdoor operating conditions .46

Fig. 4.12 Total electrical energy generation over a year under different annealing cycles in Casa Grande, AZ at outdoor operating conditions

Fig. 4.13 Total electrical energy generation over a year under different annealing cycles in Apalachicola, FL at outdoor operating conditions...

Fig. 4.14 Total electrical energy generation over a year under different annealing cycles in Aspen, $\mathrm{CO}$ at outdoor operating conditions .48

Fig. 4.15 Maximum electrical energy generation over a year for the four cities at sustained temperature (anneal cycle is one time per day) and outdoor operating conditions (anneal cycle varies from one place to another) 



\section{LIST OF TABLES}

Table 2.1 Cases for the dispatch strategy of spike annealing of a-Si:H type PV/T .20

Table 2.2 Summary of climate for cities chosen for simulation .22

Table 3.1: Total energy generation over a year for the four cities for different case studies

Table 4.1: Chosen cities based on atmospheric criteria

Table 4.2 Summary of climate of the chosen cities

Table 4.3 Normalized max electrical energy generation with respect to $25{ }^{\circ} \mathrm{C}$ max energy at sustained operating temperatures (anneal cycle: once every day)

Table 4.4 List of case studies for outdoor operating temperature

Table 4.5 Max electrical energy generation over a year in the four cities at outdoor operating temperature

Table 4.6 Comparison between max electrical energy dispatch strategies and appropriate strategies .53 



\section{PREFACE}

In the present era of sustainable development, amorphous silicon based solar cells have the potential to contribute to the elevating energy demand and produce clean energy. The economic viability and the dual operation of thermal/ solar power collection makes amorphous silicon based PV/T a good candidate for commercial and household application. Being a recent one, the technology has a wide window open ahead with a lot of development opportunities. This study focuses on one of the most unique features of a-Si:H i.e. degradation and annealing effect and portrays technically sound global dispatch mechanism. The study is conducted under supervision of Dr. Joshua M. Pearce with approval from the Department of Electrical and Computer Engineering, Michigan Technological University. This thesis is composed of two papers, one of which is published and one submitted for publication. The author's contributions are described hereafter.

The methodology of Chapter 2 and the results of Chapter 3 are "The effects of dispatch strategy on electrical performance of amorphous silicon-based solar photovoltaic-thermal systems" published in Renewable Energy 68, pp. 459-465 (2014). This article was written by J. Rozario, A.H. Vora, S.K. Debnath, M.J.M. Pathak, and J.M. Pearce. J. Rozario's contribution to this paper was helping with the literature review, revising the simulation code and completing the simulations, remaining analysis, results, figures, writing, and multiple revisions. A.H. Vora and S.K. Debnath's contributions was starting the simulation code and helping with the literature review and the writing. M.J.M. Pathak helped with the literature review and made the experimental measurements. J. M. Pearce's contribution was writing, editing, and consultation.

The results of Chapter 4 are "Optimization of annealing cycles for electric output in outdoor Conditions for amorphous silicon photovoltaic thermal systems" to be published by J. Rozario and J. M. Pearce. J. Rozario's contribution to this paper was the literature review, writing the simulation code and completing the simulations, remaining analysis, results, figures, writing, and multiple revisions. J. M. Pearce's contribution was writing, editing, and consultation. 



\section{ACKNOWLEDGEMENTS}

The study reflects my research work on photovoltaics during my involvement with Michigan Technological University from 2012 to2014. I was fortunate to have really supportive colleagues and mentors beside me all this time. They all share the credit for the job.

I would like to convey my sincere gratitude to Dr. Joshua M. Pearce who has guided and encouraged me relentlessly all this time as my supervisor. It has been an honor working with him.

This work was supported by the Winn Fellowship, Natural Sciences and Engineering Research Council of Canada, Canada Foundation for Innovation, Ministry of Research and Innovation, the Canadian Solar Building Network, and PV Measurements Inc. I would like to acknowledge K. Girotra for providing samples, S. Harrison, Rob Andrews for helpful discussions. Finally, I would also like to thank my family, friends and coauthors from the published work. 



\section{LIST OF ABBREVIATIONS}

$\begin{array}{ll}\text { AM1.5 } & \text { Airmass } 1.5 \\ \text { a-Si } & \text { Amorphous Silicon } \\ \text { a-Si:H } & \text { Hydrogeneted Amorphous Silicon } \\ \text { AZO } & \text { Azobenzene Compound } \\ \text { CMOS } & \text { Complementary Metal-Oxide-Semiconductor Field Effect Transistor } \\ \text { c-Si } & \text { Crystalline Silicon } \\ \text { DSS } & \text { Degraded/Degenerated Steady State } \\ \text { ITO } & \text { Indium Tin Oxide } \\ \text { PECVD } & \text { Plasma Enhanced Chemical Vapor Deposition } \\ \text { TCO } & \text { Transparent Conducting Oxide } \\ \text { p-i-n } & \text { p type-intrinsic layer-n type } \\ \text { PV } & \text { Photovoltaic } \\ \text { PV/T or PVT } & \text { Solar Photovoltaic Thermal System } \\ & \text { Silicon Heterojunction } \\ & \end{array}$





\begin{abstract}
Previous work has shown that high-temperature short-term spike thermal annealing of hydrogenated amorphous silicon (a-Si:H) photovoltaic thermal (PVT) systems results in higher electrical energy output. The relationship between temperature and performance of a-Si:H PVT is not simple as high temperatures during thermal annealing improves the immediate electrical performance following an anneal, but during the anneal it creates a marked drop in electrical performance. In addition, the power generation of a-Si:H PVT depends on both the environmental conditions and the Staebler-Wronski Effect kinetics. In order to improve the performance of a-Si:H PVT systems further, this paper reports on the effect of various dispatch strategies on system electrical performance. Utilizing experimental results from thermal annealing, an annealing model simulation for a-Si:Hbased PVT was developed and applied to different cities in the U.S. to investigate potential geographic effects on the dispatch optimization of the overall electrical PVT systems performance and annual electrical yield. The results showed that spike thermal annealing once per day maximized the improved electrical energy generation. In the outdoor operating condition this ideal behavior deteriorates and optimization rules are required to be implemented.
\end{abstract}





\section{CHAPTER 1}

\section{Introduction}

For the past few decades the semiconductor industry is mostly dominated by silicon based technologies. Although silicon has an indirect band-gap, no other technology has surpassed the popularity of silicon based technology due to its abundance, state of the art native insulating oxide and nitride with high dielectric constants and good electro-thermal properties. With the development of hetero-structure devices based on II-VI and III-V semiconductors the complementary-metal-oxide-semiconductor (CMOS) technology based on silicon is still the most important device in the industry. Even the photovoltaic industry has adopted silicon based technology commercially. Photovoltaic (PV) is a sustainable and pollution free technology that converts sunlight directly into electricity. In recent years, significant growth has been observed in this green energy sector. The reliability and the environment friendly features of PV have made it unique among the renewable energy and sustainable technology disciplines. In its interaction with the built environment, PV is becoming part of the daily experience of citizens in developed countries as millions of PV modules are installed every year [1]. Alongside the environmental aspects the solar energy harvesting of PV technology has a positive impact on economy as well.. As a whole in US, the solar energy industry grew a total of $67 \%$ between 2009 and 2010 nationally and is now responsible for over 100,000 jobs, in over 5,000 businesses [2]. In order to manage solar industry to play a more prominent role in economy and to be economically competitive improving the efficiency of the cells and lowering their manufacturing costs is necessary. 


\subsection{Background}

The availability of solar energy far exceeds any conceivable future energy demands. It is environmentally clean, and carbon free technology. Present day's commercial solar cells, most often made from silicon; typically convert sunlight into electricity with an efficiency of only 10 percent to 20 percent [3]. Given their manufacturing costs, these solar modules incorporated in the power grid produce electricity at a cost roughly 3 to 6 times higher than current prices, or 18-30 cents per kilowatt hour [3]. Thus the present day researches mostly focus on improving the cell efficiency and lowering the manufacturing costs. It has been reported that the standard PV cells based on Si has theoretical efficiency of $31 \%$ and PV cells based on other novel materials has shown a maximum of $40 \%$ experimental efficiency [3]. According to the latest NPD Solarbuzz_PV Equipment Quarterly report, the polycrystalline Si solar modules are expected to dominate the industry in 2014 with p-type poly c-Si technology accounting for $62 \%$ of all modules produced [4].

Mono and poly crystalline silicon (c-Si) solar photovoltaic (PV) cells are used in the largest quantity on the market, representing about $80-90 \%$ of the world total PV cell production according to data obtained in 2012 [5]. The highest energy conversion efficiency reported so far for experimental crystalline silicon PV cells is 25\% [6]. High-efficiency research PV cells have advantages in performance but are often unsuitable for low-cost production due to their complex structures, high temperature procedures and the prolonged manufacturing processes required for fabrication [6]. High energy conversion efficiency and low processing cost can only be achieved simultaneously through the development of advanced production technologies and equipment. One good alternative with minimized costs can be silicon heterojunction technology ( $\mathrm{Si}-\mathrm{HJT}$ ) which allows solar cells with energy conversion efficiencies above $20 \%$ at industrial-production level [7]. Thin film Si solar cells consist of thin amorphous silicon (a-Si) layers on monocrystalline silicon wafers. The key feature of these structures is the displacement of highly recombination-active (ohmic) contacts from the crystalline surface by insertion of a wide bandgap intrinsic film [7]. Also to obtain full device potential, the hetero-interface state density is 
required to be at its minimum [7]. In reality, hydrogenated amorphous silicon (a-Si:H) films of only a few nanometer thickness are suitable selection for this. Their bandgap is wider than that of crystalline silicon (c-Si) and intrinsic films of hydrogenated a-Si can reduce the c-Si surface state density [7]. Additionally, doping of these films is easier (either $\mathrm{n}$ - or p-type) and allows lithography-free fabrication of contacts with low saturationcurrent density [7]. The technology involved in growing amorphous silicon is relatively easier and simple compared to growing crystals. The optical property of a-Si:H is also superior to c-Si and that makes them promising for collecting solar energy as the active layer. The absorption coefficient of a-Si:H is high with minimized reflection compared to c-Si [8]. That point out the fact that for the same light energy absorption a-Si:H requires thinner layers compared to c-Si. That implies that comparatively less materials are required for making PV cells out of a-Si:H than from c-Si [9]. Therefore besides the a$\mathrm{Si}: \mathrm{H} / \mathrm{c}-\mathrm{Si}$ heterojunction technology other photovoltaic cells based on $\mathrm{p}-\mathrm{i}-\mathrm{n}$ a-Si:H device structures has promising future in PV market.

One unique application of hydrogenated amorphous silicon (a-Si:H) can be photovoltaic thermal hybrid solar collectors, also known as hybrid PV/T systems or PVT, are systems that convert solar radiation into thermal and electrical energy. These systems combine a photovoltaic cell with a solar thermal collector and perform dual operation-1) converts light energy i.e. photons into electricity and 2) captures the remaining energy and collects waste heat from the PV module. The capture of both heat and electricity allow these devices to have higher exergy [10] and thus be more overall energy efficient than stand-alone solar photovoltaic (PV) or solar thermal [11].

Photovoltaic cell efficiency falls with the rise in temperature due to increased resistance. Employing PV/T's can be advantageous in the way that it carries heat away from the modules thereby cooling the cells and thus improving their efficiency by lowering resistance [12]. Although this is a more successful method, it causes the thermal component to under-perform compared to a stand-alone solar thermal collector. Photovoltaic materials with low temperature coefficients such as amorphous silicon PV 
allow the $\mathrm{PV} / \mathrm{T}$ to be operated at high temperatures, promoting a more unified PVT system.

\subsection{Hydrogenated Amorphous Silicon in Photovoltaic Thermal System}

Despite improvements in solar photovoltaic (PV) efficiency, which reduces the cost of PV generated electricity to competitive levels in some markets [13], in conventional cells much of the radiation above the bandgap does not contribute to electrical energy generation and instead is wasted as heat. On the other hand, solar thermal systems, which have the potential for high efficiencies, have low exergy values [14]. Thus, developing photovoltaic solar thermal (PVT) systems offer a distinct advantage over simple PV or low exergy solar thermal systems by utilizing this waste thermal energy from the PV absorber for heating applications [15]. PVT offers advantages in overall exergy, energy and cost [14-21]. Historically, most of the PVT systems were developed using crystalline silicon (c-Si) PV, which have a thermal coefficient of $-0.45 \% / \mathrm{K}$ [22]. Because of this relatively large thermal coefficient c-Si-based PVT systems are designed to cool the c-Si PV modules in order to maximize the electrical output and extracted thermal energy is considered as secondary benefit. This results in non-optimization of c-Si-based PVT systems because the thermal component under-performs when compared to standard solar thermal collectors [23-27].

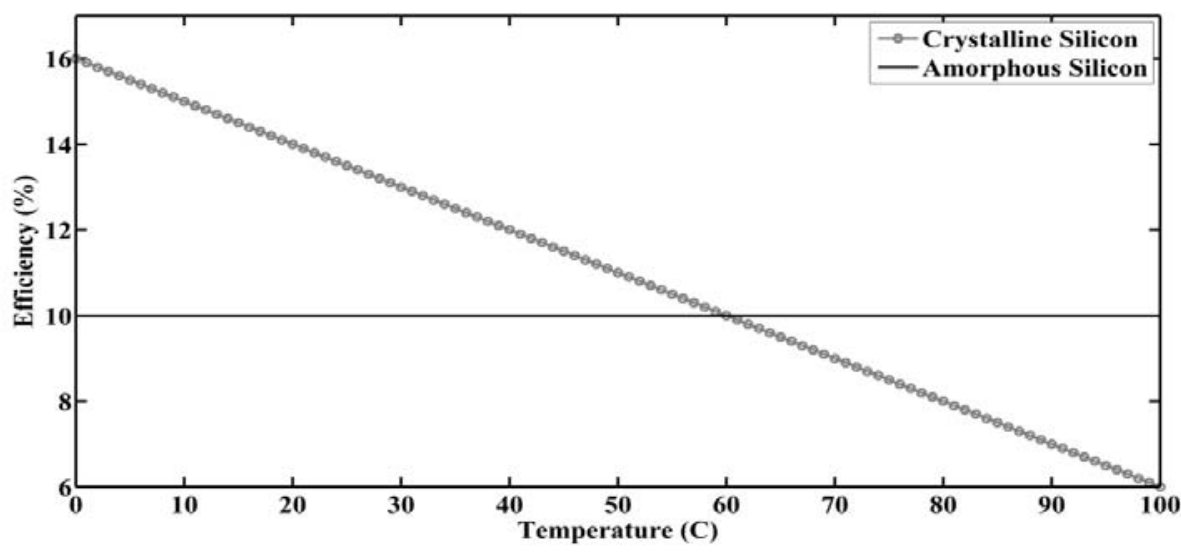

Fig. 1.1 Temperature Vs efficiency plot for crystalline and amorphous silicon PV cells 
Thin-film hydrogenated amorphous silicon (a-Si:H) solar cells, however, have a thermal coefficient of only $0.13 \% / \mathrm{K}$ [22], which makes it suitable for high temperature applications that are not possible with c-Si PV due to what would be significant electrical output losses at high operating temperatures. Unlike c-Si the efficiency drop with temperature is negligible in amorphous silicon cells. Figure 1.1 shows the temperature versus efficiency plot for commercially manufactured c-Si and a-Si PV cells. The biggest technical challenge confronting a-Si:H PV is a light-induced degradation of performance known as the Staebler-Wronski effect (SWE) [28-32]. This effect is associated with the creation of defect states in the a-Si:H material when exposed to sunlight, which causes a reduction in efficiency of the solar cells with exposure time [29]. These defects states tend to saturate after an extended exposure to sunlight (approximately $100 \mathrm{~h}$ under continuous 1 sun illumination) and this stabilized state is referred as degraded steady-state (DSS) $[33,34]$. However, it has been found that SWE is reversible in nature and the performance (efficiency) of a-Si:H solar cell can be returned to its initial state if the cell is heated to $150{ }^{\circ} \mathrm{C}$ for $4 \mathrm{~h}$ as the defect states are annealed $[29,33,35,36]$ although the defect states can anneal at lower temperatures over more extended time periods [33]. Reducing SWE is viewed as so important, that Pola et al. have even suggested removing entire PV arrays and annealing the modules in a hot air oven at lower temperatures (e.g. at $80{ }^{\circ} \mathrm{C}$ ) over extended times [37]. Additionally, because of this effect it has been reported that a-Si:H PV performs better at high temperatures in view of the fact that optoelectronic properties of a-Si:H materials [28,38,39] stabilize at a higher efficiency at higher temperatures $[34,40]$. Operating at elevated temperatures is highly desirable for PVT hybrid systems as the solar thermal efficiency increases with temperature. For a solar thermal flat plate collector a temperature of $100{ }^{\circ} \mathrm{C}$ can be easily achieved and if the system is stagnated it can even climb higher than $200{ }^{\circ} \mathrm{C}$ [41]. Therefore, direct deposition of a-Si:H PV over flat plate solar collectors can facilitate high-temperature operation where the PV panel could be in-situ annealed and simultaneously increasing overall system exergy [42-44]. It has also been experimentally demonstrated that high temperature operation and regular high temperature spike thermal annealing for $1 \mathrm{~h}$ at $100{ }^{\circ} \mathrm{C}$ on a 12 h cycle can result in higher energy and exergy output [45]. However, a dispatch strategy 
is required to optimize the usage of available resources to meet the electrical and thermal demand and to maximize the overall system efficiency. Although spike thermal annealing of a-Si:H PV panels with short thermal spikes can improve the immediate electrical performance following an anneal, the annealing process at high temperatures creates a marked drop in electrical performance over the annealing period (it can also deteriorate the overall thermal performance of the system as the thermal energy required for spike annealing is not being extracted). It has also been observed that, the degraded steady state is obtained more rapidly at higher temperature at a higher power [45]. Therefore a dispatch strategy is required to optimize the number of required spike thermal annealing cycles in order to maximize the overall system performance including the thermal and electrical output.

\subsection{Objective}

The present work reports on the effects of various dispatch strategies on the first of these outputs- the electrical system performance. Utilizing experimental results from thermal annealing, an annealing model simulation for a-Si:H-based PVT was developed and applied to different cities (Goldendale, San Antonio, Reno and Las Vegas) in U.S. to investigate the effects of geographic optimization on the overall electrical PVT systems performance. The aim and objective are following:

I. Analyze the degradation data set for different operating temperature.

II. Derive suitable equations that take into account the light-induced degradation effect of a-Si:H PV cell at different operating temperatures. Required for identifying the fitting curve for the reference data.

III. Develop a simulation model that combines the degradation and spike annealing effects and calculate additional energy generation. This explains the annealing effect under 1 sun $\left(1000 \mathrm{~W} / \mathrm{m}^{2}\right.$ solar irradiation) illumination.

IV. Input real time solar irradiation data collected for different cities in the simulation model in order to observe the real world scenario. 
V. Observe the real time simulation results while employed in specific cases of dispatch strategies. Evaluate the outcome from different dispatch strategies. Required for determining the ideal dispatch strategy.

VI. Observe non-ideal cases. Determine factors playing major roles over dispatch strategies.

\subsection{Device Structure and Degradation Characteristics}

The contemporary work utilizes Pathak et al.'s device structure and experimental data as the reference model for device layout and light-induced degradation spike annealing characteristics of thin film a-Si:H PV cells [45]. The cell being considered in the simulation model has an i-layer thicknesses of $630 \mathrm{~nm}$ - deposited on transparent conducting oxide (TCO) glass substrate, prepared in plasma enhanced chemical vapor deposition (PECVD) system. Fig. 1.2 shows the device configuration used in this investigation include following layers from bottom to cell up: AGC float glass (3 $\mathrm{mm}) / \mathrm{SnO}_{2}: \mathrm{F}(700 \mathrm{~nm}) / \mathrm{Ag}(200 \mathrm{~nm}) / \mathrm{AZO}(100 \mathrm{~nm}) / \mathrm{n}-\mathrm{a}-\mathrm{Si}: H 25 \mathrm{~nm} / \mathrm{i}-\mathrm{a}-\mathrm{Si}: H \mathrm{H} 630 \mathrm{~nm} / \mathrm{p}$-aSi:H $15 \mathrm{~nm} / \mathrm{ITO} 70 \mathrm{~nm}$. Fig. 1.3 shows the light induced degradation characteristics for the reference cell at operating temperatures $25{ }^{\circ} \mathrm{C}, 50{ }^{\circ} \mathrm{C}$ and $90{ }^{\circ} \mathrm{C}$ respectively.

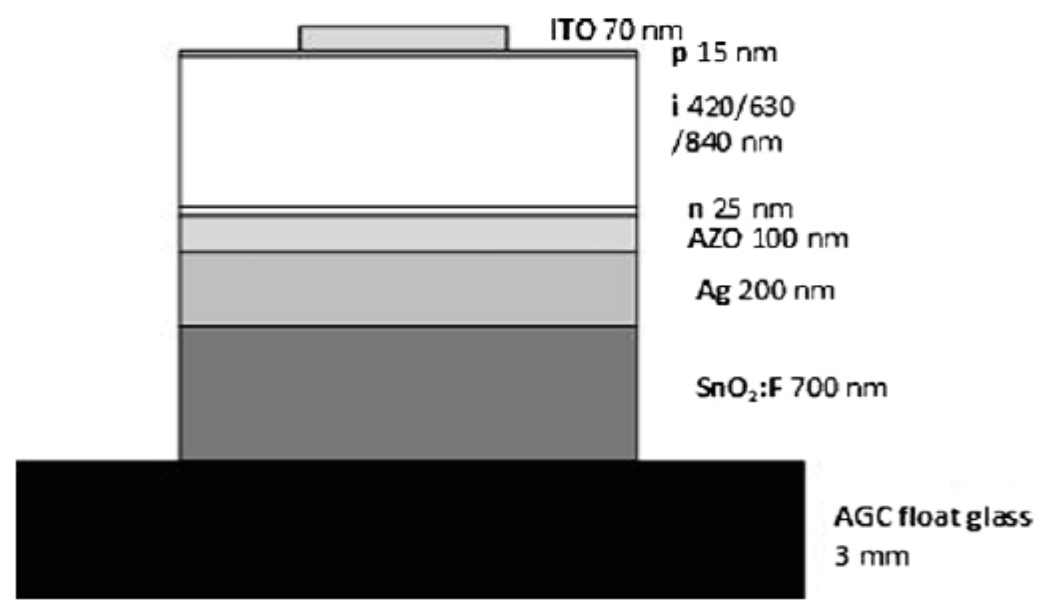

Fig. 1.2: Composition and structure of the a-Si:H solar photovoltaic cell (device with $630 \mathrm{~nm}$ i-layer thickness considered as reference model) [45] 


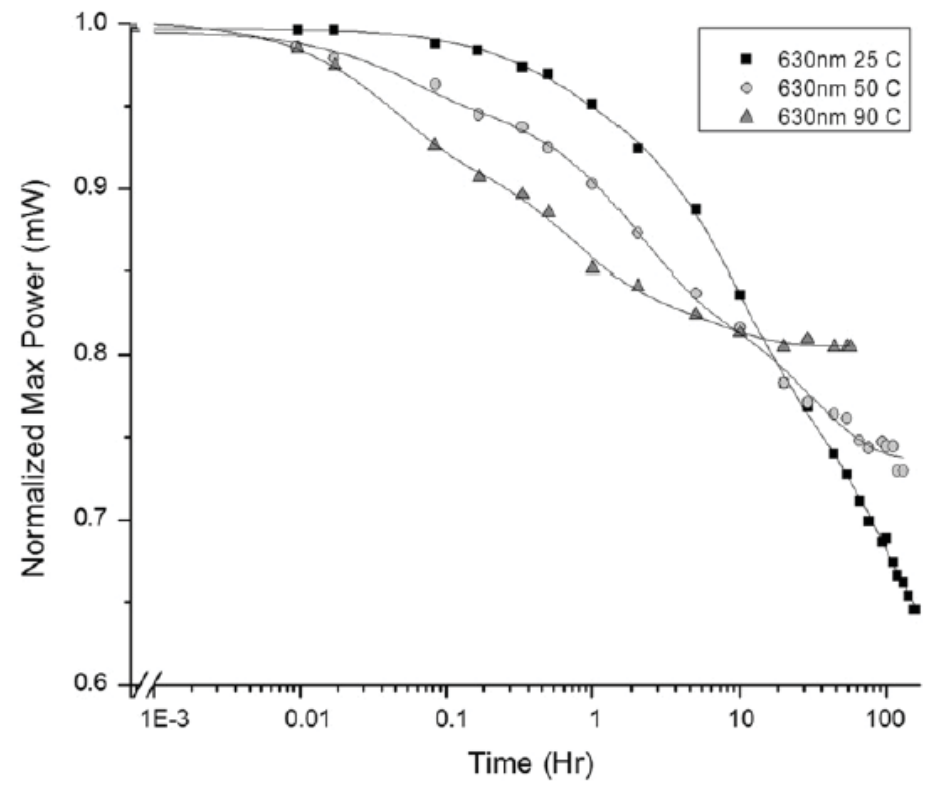

Fig. 1.3: A normalized temperature series of 25,50 and $90{ }^{\circ} \mathrm{C}$ degradation under 1 sun for a PV cell with an i-layer thickness of $630 \mathrm{~nm}$ [45]

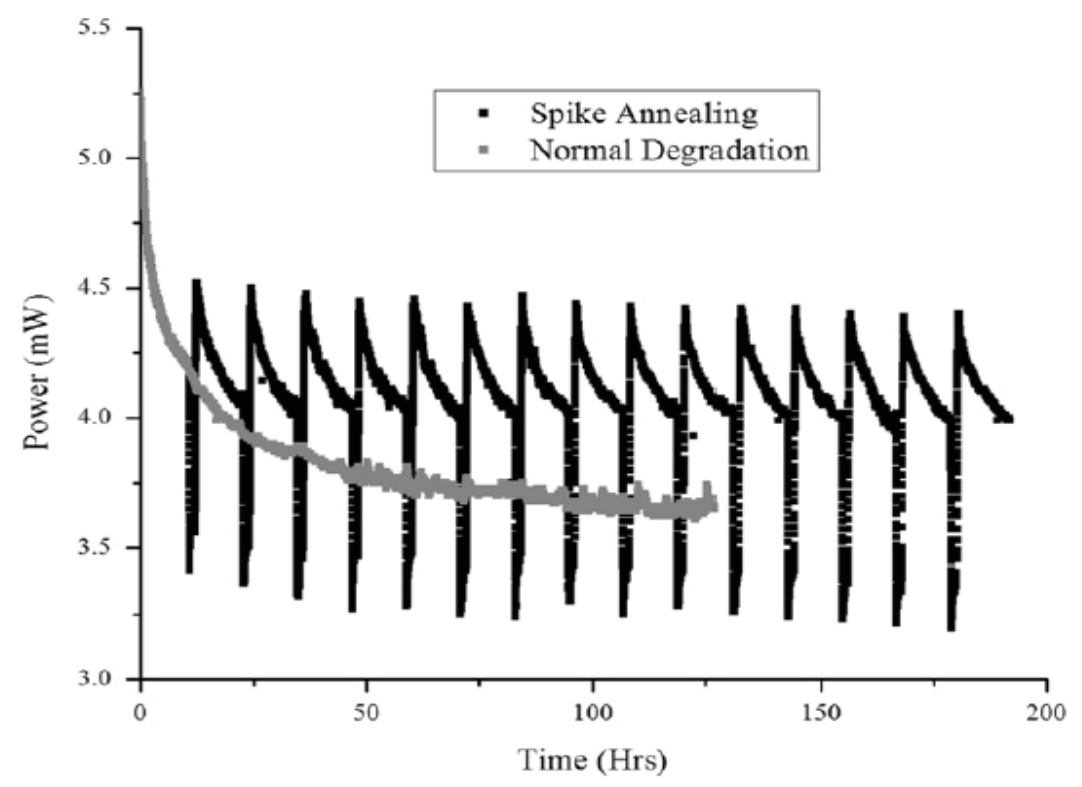

Fig. 1.4 Comparison of the same $630 \mathrm{~nm}$ i-layer thick a-Si:H PV cell degraded at 50 ${ }^{\circ} \mathrm{C}$ under 1 sun (Normal Degradation) to results obtained for degradation at $50{ }^{\circ} \mathrm{C}$ under 1 sun coupled with spike annealing at $100{ }^{\circ} \mathrm{C}$ on a $12 \mathrm{~h}$ cycle for $192 \mathrm{~h}$ (Spike Annealing) [45] 
Fig. 1.4 shows the spike-annealing effect at operating temperature $50{ }^{\circ} \mathrm{C}$. The reference data clearly shows additional energy generation as a consequence of spike annealing. It should be noted that all of these data were recorded while the device is illuminated at 1 sun $\left(1000 \mathrm{~W} / \mathrm{m}^{2}\right)$ solar irradiation.

\subsection{Outline}

The Chapters are organized in following order:

Chapter 2 'Methodology' introduces the simulation and modeling steps, procedures in detail. That includes the modification of equations, curve fitting technique of the reference data, acquisition of real-time data and different cases of dispatch strategies that will be studied.

Chapter 3 'Results: Ideal Cases' concentrates on the obtained simulation results at sustained operating temperature conditions. The results obtained for 1 sun illumination are discussed in thorough. Real-data simulation results for different dispatch strategies are also presented in this section.

Chapter 4 'Results: Outdoor Temperature Simulation' focus mostly on the effects of temperature and geographic position on degradation associated parameters and how annealing influence device outcome at outdoors. This chapter also discusses about the appropriate dispatch strategies.

Chapter 5 Discussion, Future Work and Conclusions summarizes the notations made from earlier discussion and directs toward a suitable conclusion. It also discuss about the future scope of this fascinating technology. 


\section{CHAPTER REFERENCES}

[1] Lynn PA. Electricity from Sunlight: An Introduction to Photovoltaics. Solar Energy and Photovoltaics: Wiley; 2010.

[2] How solar energy impacts the economy. The S.U.N Report, Solar Energy World US News. <http://www.solareworld.com/2011/12/09/how-solar-energy-impacts-theeconomy/>; 2013

[3] Make solar energy economical. National Academy of Engineering. $<\mathrm{http}$ //www.engineeringchallenges.org/cms/8996/9082.aspx>

[4] Multicrystalline Silicon Modules to Dominate Solar PV Industry in 2014, According to NPD Solarbuzz. NPD Solarbuzz, Solar Market Research Analysis. $<\mathrm{http}$ //www.solarbuzz.com/news/recent-findings/multicrystalline-silicon-modulesdominate-solar-pv-industry-2014>; 2013

[5] Technologies. NPD Solarbuzz, Solar Market Research Analysis. $<$ http://www.solarbuzz.com/going-solar/understanding/technologies>; 2014

[6] Saga T. Advances in crystalline silicon solar cell technology for industrial mass production. NPG Asia Materials 2010; 2:96-102. doi:10.1038/asiamat.2010.82.

[7] Wolf SD, Demaurex B, Geissbuehler J, Holm N, Ledinsky M, Löper P, Nicolas SM, Paviet B, Seif J, Tomasi A. a-Si/c-Si Heterojunction Solar Cells: High-efficiency crystalline / amorphous silicon heterojunction solar cells. Photovoltaics and Thin film Electronics Laboratory.

[8] Mort J, The Anatomy of Xerography: Its Invention and Evolution. Jefferson, NC: McFarland; 1989.

[9] Chittick R, Sterling H. In: Adler D, Fritzsche, H editors, Tetrahedrally Bonded Amorphous Semiconductors, New York: Plenum Press; 1985, pp. 1-11. 
[10] Pathak MJM, Sanders PG, Pearce JM. Optimizing limited solar roof access by exergy analysis of solar thermal, photovoltaic, and hybrid photovoltaic thermal systems. Applied Energy 2014;120:115-24. http://dx.doi.org/10.1016/j.apenergy.2014.01.041.

[11] Mojiri A, Taylor RA, Thomsen E, Rosengarten G, Spectral beam splitting for efficient conversion of solar energy - A review. Renewable and Sustainable Energy Reviews 2013;28:654-663. doi: 10.1016/j.rser.2013.08.026

*[12] Kalogirou SA, Tripanagnostopoulos Y. These systems are most often used for domestic hot water (DHW) and electricity production. 2006

[13] Branker K, Pathak MJM, Pearce JM. A review of solar photovoltaic levelized cost of electricity. Renew Sustain Energy Rev 2011;15:4470-82. http://dx.doi.org/10.1016/j.rser.2011.07.104.

[14] Chow TT. A review on photovoltaic/thermal hybrid solar technology. Appl Energy 2010;87:365-79. http://dx.doi.org/10.1016/j.apenergy.2009.06.037.

[15] Tripanagnostopoulos Y, Nousia T, Souliotis M, Yianoulis P. Hybrid photovoltaic/thermal solar systems. Solar Energy 2002;72:217-34. http://dx.doi.org/10.1016/S0038-092X(01)00096-2.

[16] Huang BJ, Lin TH, Hung WC, Sun FS. Performance evaluation of solar photovoltaic/thermal systems. Solar Energy 2001;70:443-8. http://dx.doi.org/10.1016/S0038-092X(00)00153-5.

[17] Derewonko P, Pearce JM. Optimizing design of household scale hybrid solar photovoltaic $\mathrm{p}$ combined heat and power systems for Ontario. In: 34th Proceedings of IEEE Photovoltaic Specialists Conference (PVSC); 2009. pp. 001274-9. doi: 10.1109/PVSC.2009.5411247.

[18] Assoa YB, Menezo C, Fraisse G, Yezou R, Brau J. Study of a new concept of photovoltaic-thermal hybrid collector. Solar Energy 2007;81:1132-43. http://dx.doi.org/10.1016/j.solener.2007.04.001. 
[19] Vorobiev YV, Gonzalez-Hernandez J, Kribus A. Analysis of potential conversion efficiency of a solar hybrid system with high-temperature stage. J Sol. Energ Eng 2006;128:258-60. http://dx.doi.org/10.1016/j.solener.2005.04.022.

[20] Kalogirou SA, Tripanagnostopoulos Y. Hybrid PV/T solar systems for domestic hot water and electricity production. Energ Convers Manage 2006;47:3368-82. http://dx.doi.org/10.1016/j.enconman.2006.01.012.

[21] Jardan RK, Nagy I, Cid-Pastor A, Leyva R, El Aroudi A, Martinez-Salamero L. Combined photovoltaic/thermal energy system for stand-alone operation. Proc IEEE Int Sympos Indust Electron; 2007:2403-8. http://dx.doi.org/10.1109/ISIE.2007.4374983.

[22] Virtuani A, Pavanello D, Friesen G. Overview of temperature coefficients of different thin film photovoltaic technologies. In: 25th European photovoltaic solar energy conference and exhibition/5th World conference on photovoltaic energy conversion; 2010. pp. 6-10.

[23] Wormser P, Strong S. Evaluation of the potential for use of new thin film photovoltaic materials as selective surfaces for solar thermal absorbers in flatplate combined photovoltaic/thermal collectors. ASHRAE Final Report \#1109-RP, 2006, pp. $1-23$.

[24] Schweizer E, Enecolo AG. LESO-PB, new generation of hybrid solar PV/T collectors. Final Report DIS 56360/16868, 2000, pp. 1-55.

[25] Fraisse G, Ménézo C, Johannes K. Energy performance of water hybrid PV/T collectors applied to combisystems of Direct Solar Floor type. Solar Energy 2007;81:1426-38. http://dx.doi.org/10.1016/j.solener.2006.11.017.

[26] Zondag HA, de Vries DW, van Helden WGJ, van Zolingen RJC, van Steenhoven AA. The yield of different combined PV-thermal collector designs. Solar Energy 2003;74:253-69. http://dx.doi.org/10.1016/S0038-092X(03)00121-X. 
[27] Vorobiev Y, González-Hernández J, Vorobiev P, Bulat L. Thermal-photovoltaic solar hybrid system for efficient solar energy conversion. Solar Energy 2006;80:170-6. http://dx.doi.org/10.1016/j.solener.2005.04.022.

[28] Wronski CR, Pearce JM, Deng J, Vlahos V, Collins RW. Intrinsic and light induced gap states in a-Si:H materials and solar cells e effects of microstructure. Thin Solid Films 2004;451-452:470-5. http://dx.doi.org/10.1016/j.tsf.2003.10.129.

[29] Staebler DL, Wronski CR. Reversible conductivity changes in discharge produced amorphous Si. Appl Phys Lett 1977;31:292-4. http://dx.doi.org/10.1063/1.89674.

[30] Fritzsche H. Development in understanding and controlling the Staebler-Wronski effect in a-Si:H. Annu Rev Mater Res 2001;31:47-79.

[31] Deng J, Albert ML, Pearce JM, Collins RW, Wronski CR. The nature of native and light induced defect states in i-layers of high quality a-Si:H solar cells derived from dark forward bias currentevoltage characteristics. Mater Res Soc Sympos Proc 2005;862. http://dx.doi.org/10.1557/PROC-862-A11.4. A11.4.

[32] Klaver A, van Swaaij RACMM. Modeling of light-induced degradation of amorphous silicon solar cells. Solar Energy Mater Solar Cells 2008;92:50-60. http://dx.doi.org/10.1016/j.solmat.2007.08.010.

[33] Pearce JM, Deng J, Albert ML, Wronski CR, Collins RW. Room temperature annealing of fast state from 1 sun illumination in protocrystalline Si:H materials and solar cells. In: 31st IEEE Photovoltaic Specialists Conference Proceedings; 2005. pp. 1536-9. doi:10.1109/PVSC.2005.1488436.

[34] Wronski CR, Pearce JM, Koval RJ, Niu X, Ferlauto AS, Koh J, et al. Light induced defect creation kinetics in thin film protocrystalline silicon materials and their solar cells. Mater Res Soc Sympos Proc 2002;715. http://dx.doi.org/10.1557/PROC-715A13.4. A13.4. 
[35] Fujikake S, Ota H, Ohsawa M, Hama T, Ichikawa Y, Sakai H. Light-induced recovery of a-Si solar cells. Solar Energy Mater Solar Cells 1994;34:449e54.http://dx.doi.org/10.1016/0927-0248(94)90072-8.

[36] Albert ML, Deng J, Niu X, Pearce JM, Collins RW, Wronski CR. The creation and relaxation kinetics of light induced defects in a-Si:H located at different energies in the gap. Mater Res Soc Sympos Proc 2005;862. http://dx.doi.org/10.1557/PROC-862A13.2. A13.2.

[37] Pola I, Chianese D, Fanni L, Radel R. Analysis of annealing and degradation effects on a-Si modules Source. In: Proceedings of the 23rd European Photovoltaic Solar Energy Conference and Exhibition, 1e5 September 2008, Valencia, Spain, pp. 2301-4.

[38] Pearce JM, Deng J, Collins RW, Wronski CR. Light-induced defect states in hydrogenated amorphous silicon centered around 1.0 and $1.2 \mathrm{eV}$ from the conduction band edge. Appl Phys Lett 2003;83(18):3725-7. http://dx.doi.org/10.1063/1.1624637.

[39] Pearce J, Niu X, Koval R, Ganguly G, Carlson D, Collins RW, et al. Contributions of DO and non-DO gap states to the kinetics of light induced degradation of amorphous silicon under 1 sun illumination. Mater Res Soc Sympos Proc 2001;664. http://dx.doi.org/10.1557/PROC-664-A12.3. A12.3.

[40] Ruther R, Tamizh-Mani G, del Cueto J, Adelstein J, Dacoregio MM, von Roedern B. Performance test of amorphous silicon modules in different climates e year three: higher minimum operating temperatures lead to higher performance levels. In: $31 \mathrm{st}$ IEEE Photovoltaic Specialists Conference Proceedings; 2005. pp. 1635-8. doi: 10.1109/PVSC.2005.1488459.

[41] Kalogirou S. The potential of solar industrial process heat applications. Appl Energy 2003;76:337-61. http://dx.doi.org/10.1016/S0306-2619(02)00176-9. 
[42] Mahtani P, Kherani NP, Zukotynski S. The use of amorphous silicon in fabricating a photovoltaic-thermal system. In: Proceedings of the second Canadian Solar Buildings Conference; 2007. pp. 1-4.

[43] Pathak MJM, Girotra K, Harrison SJ, Pearce JM. The effect of hybrid photovoltaic thermal device operating conditions on intrinsic layer thickness optimization of hydrogenated amorphous silicon solar cells. Solar Energy 2012;86:2673-7. http://dx.doi.org/10.1016/j.solener.2012.06.002.

[44] Kalogiru SA, Tripanagnostopoulos Y. Industrial application of PV/T solar energy systems. Appl Thermal Eng 2007;27:1259-70. http://dx.doi.org/10.1016/j.applthermaleng.2006.11.003.

[45] Pathak MJM, Pearce JM, Harrison SJ. Effects on amorphous silicon photovoltaic performance from high-temperature annealing pulses in photovoltaic thermal hybrid devices. Solar Energy Mater Solar Cells 2012;100:199-203. http://dx.doi.org/10.1016/j.solmat.2012.01.015. 



\section{CHAPTER 2}

\section{Methodology}

\subsection{PV/T System*}

The PVT system shown schematically in Fig. 2.1 was used for modeling and simulation in the present work. The a-Si:H PV is connected to an inverter that powers the AC load and the heat generated by the PVT is transferred to thermal load by a heat exchanger. A temperature controller is used to control both this heat flow and the regular thermal annealing, which is provided by the heat generated from the PVT itself. High temperature spike thermal annealing for $1 \mathrm{~h}$ at $100{ }^{\circ} \mathrm{C}$ at regular cycles is carried in order to reverse Staebler-Wronski effect (SWE).

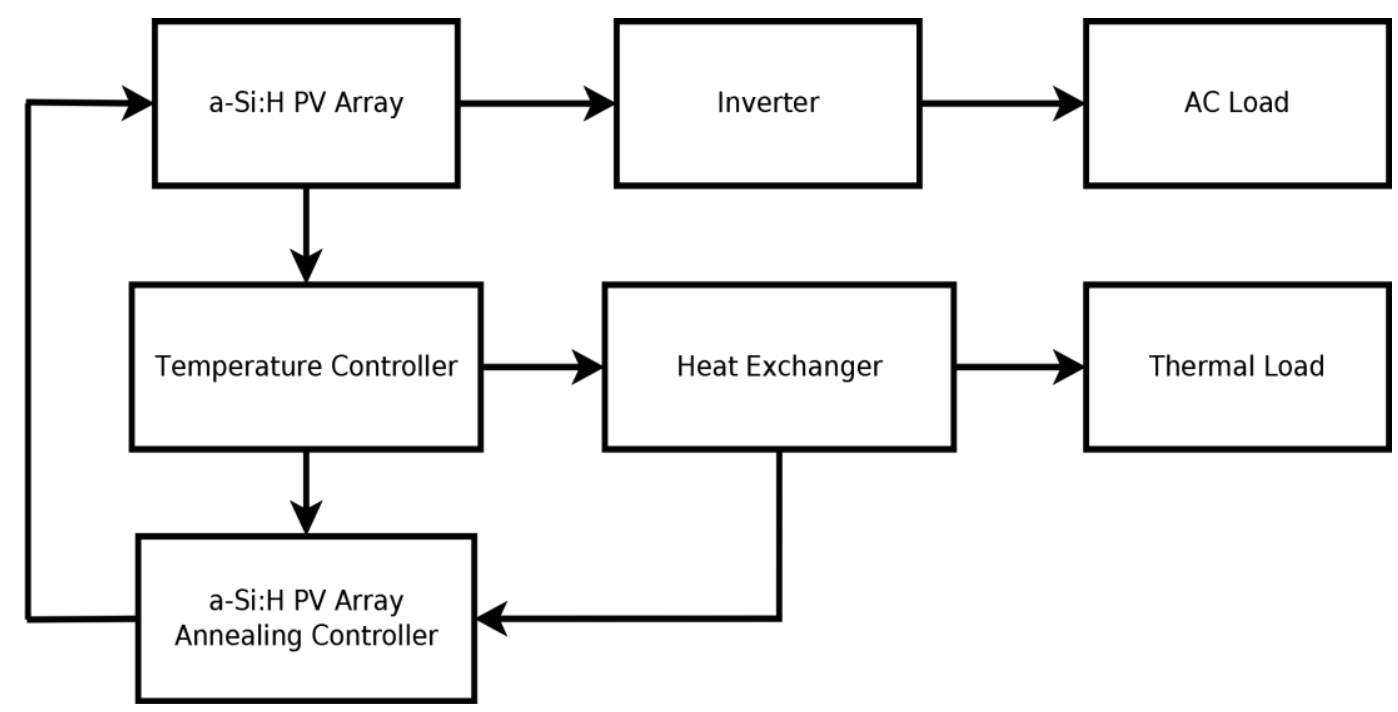

Fig. 2.1: Schematic of a-Si:H-based PVT system

\footnotetext{
* The material contained in this chapter was previously published in the journal, Renewable Energy, volume 68, pp. 459-465, August 2014.
} 


\subsection{Calculation Method}

Usually a-Si:H-based PV exhibit power degradation due to 1) the temperature effect, exhibited by all solar cells and 2) SWE, which is a long-term light exposure effect, which is a unique characteristic of a-Si:H-based solar cells. The total energy generated by the $\mathrm{PV}$ of power, $P$, for a year is given by:

$$
E=\sum_{n=1}^{365 \times 24} P_{n} \cdot t
$$

where $P_{n}$ is the power produced in the $n$th hour and $t$ is time, which is $1 \mathrm{~h}$ in this case. The maximum power, $P_{\max }(T)$, at a temperature $T$ from reference temperature $\left(T_{r e f}\right)$ having a temperature coefficient of $\gamma$ is given by [1]:

$$
P_{\text {max }}(T)=\frac{P_{\max (r e f)}}{\left(1+\gamma\left(T_{\text {ref }}-T\right)\right)} \cdot \frac{S}{S_{\text {ref }}} \cdot \frac{1}{\left(1+\delta \ln \left(\frac{S}{S_{\text {ref }}}\right)\right)}
$$

where $S$ and $S_{r e f}$ are the irradiance and reference irradiance level respectively, $P_{\max (r e f)}$ is the maximum power at a reference temperature $T_{r e f}$, which is $25{ }^{\circ} \mathrm{C}, S_{r e f}$ is equal to $1000 \mathrm{~W} / \mathrm{m}^{2}, \gamma$ is $-0.0020 /{ }^{\circ} \mathrm{C}, \delta$ is +0.063 [1]. Eq. (2.2) is used to calculate the power with no thermal annealing and universally applicable to any solar cells.

Eq. (2.2) does not take SWE into account and must therefore be modified with an exponential term that is governed by the aggregate exposure to solar flux from the annealed state and the operating temperature. The exponential terms were determined by curve fitting the experimental results of Pathak et al. [2] as shown in Fig. 2.2. 


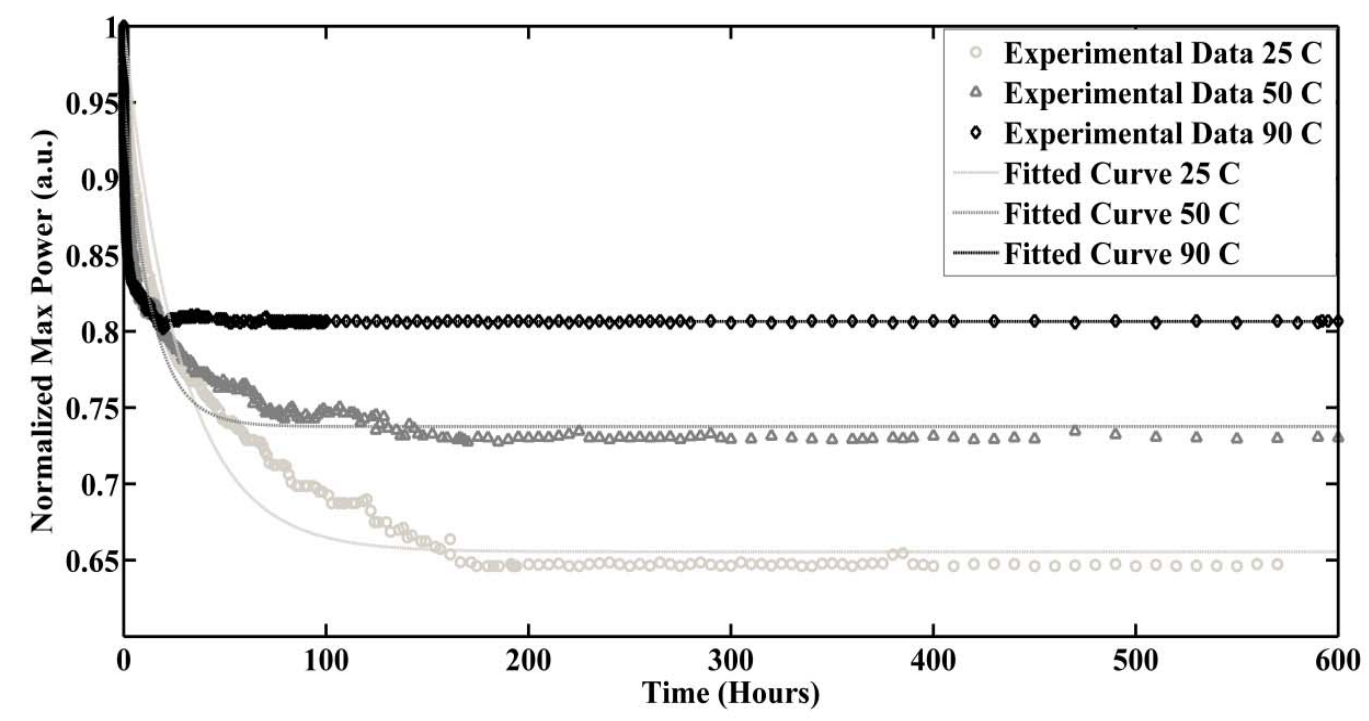

Fig. 2.2 Experimental data showing degenerated steady state obtained at temperatures $25{ }^{\circ} \mathrm{C}, 50{ }^{\circ} \mathrm{C}$, and $90{ }^{\circ} \mathrm{C}$ respectively for a-Si:H PV cell active layer thickness of $630 \mathrm{~nm}$ under 1 sun (source: Pathak et. al.) [2] and exponential fits using equation (2.3)

Fig. 2.2 shows the experimentally obtained data for degenerated steady states at different temperatures for a-Si:H based PV/T with i-layer thickness of $630 \mathrm{~nm}$ under 1 sun $\left(1000 \mathrm{~W} / \mathrm{m}^{2}\right.$ irradiance $)$ for $600 \mathrm{~h}$. For a-Si:H PVT the modified form of Eq. (2.2) is altered to be:

$$
P_{\text {max }}(T)=\left(\frac{P_{\max (r e f)}}{\left(1+\gamma\left(T_{r e f}-T\right)\right)}-k_{d s s} \cdot P_{\max (r e f)} \cdot\left(1-e^{-u_{d s s} \cdot t}\right)\right) \cdot \frac{s}{S_{r e f}} \cdot \frac{1}{\left(1+\delta \ln \left(\frac{s}{s_{r e f}}\right)\right)}
$$

The values of the parameters $k_{d s s}$ and $u_{d s s}$ were obtained by analyzing the experimental data and their values vary with temperature. For the temperatures $25{ }^{\circ} \mathrm{C}, 50$ ${ }^{\circ} \mathrm{C}$, and $90{ }^{\circ} \mathrm{C}, k_{d s s}$ has the values $0.3450,0.2154$, and 0.07917 respectively; and $u_{d s s}$ has the values $0.03601,0.07552$ and 0.2097 respectively as determined from Fig. 2.2. It should be noted that as the temperature rises $k_{d s s}$ decreases and $u_{d s s}$ increases, as is consistent with prior SWE studies of a-Si:H PV [3-5]. 


\subsection{Dispatch Strategy}

During annealing the temperature rises rapidly from normal operating temperature to high temperature $\left(\sim 100{ }^{\circ} \mathrm{C}\right)$ for a short duration $(1 \mathrm{~h})$ and this reduces electrical performance. The power drops rapidly as the temperature is increased for the anneal and then starts to rise slowly as the annealing continues. For simplification of the model the annealing period is considered constant at the reduced power.

Table 2.1 Cases for the dispatch strategy of spike annealing of a-Si:H type PV/T

\begin{tabular}{|c|c|c|}
\hline Case & Dispatch Strategy & Note \\
\hline Case I & Without annealing under 1 sun & $\begin{array}{l}\text { PVT operating temperature of } 25{ }^{\circ} \mathrm{C} \text {, } \\
50{ }^{\circ} \mathrm{C} \text {, and } 90{ }^{\circ} \mathrm{C} \text { respectively without } \\
\text { spike annealing }\end{array}$ \\
\hline Case II & $\begin{array}{l}\text { Without annealing under normal } \\
\text { sun }\end{array}$ & $\begin{array}{l}\text { PVT operating temperature of } 25^{\circ} \mathrm{C} \text {, } \\
50{ }^{\circ} \mathrm{C} \text {, and } 90^{\circ} \mathrm{C} \text { respectively without } \\
\text { spike annealing }\end{array}$ \\
\hline Case III & $\begin{array}{c}\text { With } 48 \mathrm{hr} \text { annealing cycle (under } 1 \\
\text { sun and normal sun) }\end{array}$ & $\begin{array}{c}\text { Spike annealing performed once } \\
\text { every other day between hours } 8 \text { and } \\
9\end{array}$ \\
\hline Case IV & $\begin{array}{c}\text { With } 24 \mathrm{hr} \text { annealing cycle (under } 1 \\
\text { sun and normal sun) }\end{array}$ & $\begin{array}{c}\text { Spike annealing performed once per } \\
\text { day between hours } 8 \text { and } 9\end{array}$ \\
\hline Case V & $\begin{array}{l}\text { Annealed twice per day (under } 1 \\
\text { sun and normal sun) }\end{array}$ & $\begin{array}{l}\text { Spike annealing performed twice per } \\
\text { day during the peak sun hour time } \\
\text { period (hour 8-15) with } 4 \text { hours } \\
\text { interval }\end{array}$ \\
\hline Case VI & $\begin{array}{l}\text { Annealed three times per day } \\
\text { (under } 1 \text { sun and normal sun) }\end{array}$ & $\begin{array}{l}\text { Spike annealing performed thrice per } \\
\text { day during the peak sun hour time } \\
\text { period (hour 8-15) with } 2 \text { hours } \\
\text { interval }\end{array}$ \\
\hline
\end{tabular}




\begin{tabular}{|c|c|c|}
\hline Case VII & $\begin{array}{c}\text { Annealed four times per day (under } \\
1 \text { sun and normal sun) }\end{array}$ & $\begin{array}{l}\text { Spike annealing performed } 4 \text { times } \\
\text { per day during the peak sun hour time } \\
\text { period (hour 8-15) with } 1 \text { hour } \\
\text { interval }\end{array}$ \\
\hline Case VIII & $\begin{array}{c}\text { Annealed five times per day (under } \\
1 \text { sun and normal sun) }\end{array}$ & $\begin{array}{l}\text { Spike annealing performed } 5 \text { times } \\
\text { per day during the time period (hour } \\
\text { 7-16) with } 1 \text { hour interval }\end{array}$ \\
\hline Case IX & $\begin{array}{c}\text { Annealed six times per day (under } 1 \\
\text { sun and normal sun) }\end{array}$ & $\begin{array}{l}\text { Spike annealing performed } 6 \text { times } \\
\text { per day during the time period (hour } \\
\text { 7-17) with } 1 \text { hour interval }\end{array}$ \\
\hline
\end{tabular}

Table 2.1 shows a list of different case studies (depicting different dispatch strategies) for which the simulation was performed. 1 sun solar irradiance has a constant value of $1000 \mathrm{~W} / \mathrm{m}^{2}$ and has a AM1.5 spectrum. Here 'normal sun' solar irradiance is defined as the standard hourly solar irradiance from the sun for a given location. Normal sun conditions vary over the day with real outdoor conditions. For all the above cases, the model was simulated at outdoor conditions and for various geographic locations for a year (February 1st, 2012 - January 31st, 2013) in the U.S. to better understand real-world significance of this type of PVT system under different dispatch strategy. Four different cities, namely Goldendale (Klickitat county, Washington), San Antonio (Valles Caldera, New Mexico), Reno (UNR campus, Nevada) and Las Vegas (Southern Nevada) were chosen on the basis of different geographic features and climatic conditions to better analyze the effects of different dispatch strategies. The details for the locations are shown in Table $2.2[6,7]$. 
Table 2.2 Summary of climate for cities chosen for simulation [6,7]

\begin{tabular}{|l|l|l|l|l|}
\hline City & Location & $\begin{array}{l}\text { Average Air and } \\
\text { Soil Temperature }\end{array}$ & Altitude & $\begin{array}{l}\text { Average } \\
\text { hourly solar } \\
\text { irradiance }\end{array}$ \\
\hline $\begin{array}{l}\text { Goldendale (Klickitat } 45^{\circ} 49^{\prime} 16^{\prime \prime} \mathrm{N} \\
\text { county, Washington) } \\
120^{\circ} 49^{\prime} 17^{\prime \prime} \mathrm{W}\end{array}$ & $9.4^{\circ} \mathrm{C}, 11.5^{\circ} \mathrm{C}$ & $1636 \mathrm{ft}$. & $179.09 \mathrm{~W} / \mathrm{m}^{2}$ \\
\hline $\begin{array}{l}\text { San Antonio (Valles } \\
\text { Caldera, New } \\
\text { Mexico) }\end{array}$ & $\begin{array}{l}35^{\circ} 58^{\prime} 50^{\prime \prime} \mathrm{N} \\
106^{\circ} 34^{\prime} 15^{\prime \prime} \mathrm{W}\end{array}$ & $5.3^{\circ} \mathrm{C}, 7^{\circ} \mathrm{C}$ & $8523 \mathrm{ft}$. & $206.7 \mathrm{~W} / \mathrm{m}^{2}$ \\
\hline $\begin{array}{l}\text { Reno (Nevada) } \\
39^{\circ} 32^{\prime} 21^{\prime \prime} \mathrm{N} \\
119^{\circ} 48^{\prime} 21 " \mathrm{~W}\end{array}$ & $12.5^{\circ} \mathrm{C}, 15.1^{\circ} \mathrm{C}$ & $4480 \mathrm{ft}$. & $224.6 \mathrm{~W} / \mathrm{m}^{2}$ \\
\hline $\begin{array}{l}\text { Las Vegas (Southern } \\
36^{\circ} 06^{\prime} 51^{\prime \prime} \mathrm{N} \\
\text { Nevada) }\end{array}$ & $22.3^{\circ} \mathrm{C}, 24.9^{\circ} \mathrm{C}$ & $2025 \mathrm{ft}$ & $231.0 \mathrm{~W} / \mathrm{m}^{2}$ \\
\hline
\end{tabular}

The solar irradiance, air temperature and soil temperature data was obtained on hourly basis for the four cities (Goldendale, San Antonio, Reno and Las Vegas) [6,7]. The average hourly solar irradiation data for the above mentioned cities were obtained using Eq. (2.4).

$$
S_{i=1 \text { to } 24}=\frac{1}{366} \cdot \sum_{n=1}^{366} S_{i, n, c i t y}
$$

where $S_{i}$ is the average solar irradiance for $i$ th hour of four cities (averaged yearly), and $S_{i, n, c i t y}$ is the solar irradiance for $i$ th hour and $n$th day for a year for a given location. Fig. 2.3 shows the average hourly solar irradiance for the four cities obtained using Eq. (2.4). Average solar irradiance per day for Goldendale, San Antonio, Reno, and Las Vegas are 4.30, 4.96, 5.39, and 5.54 sun hours respectively. With hour 12 being the peak sun of the day the highest sun hour period is between hours 9 and 16 in the day when the solar irradiance is higher than $250 \mathrm{~W} / \mathrm{m}^{2}$. Therefore spike annealing is used between hours 8 and 15 as seen in Fig. 2.3. 


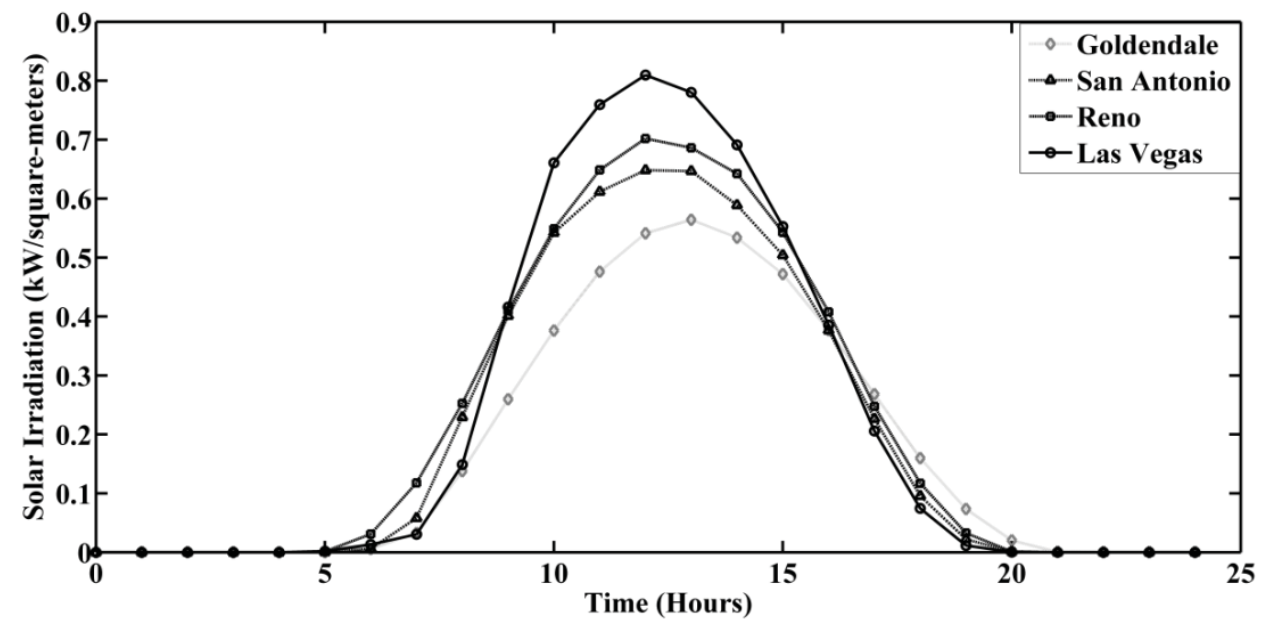

Fig. 2.3: Average hourly solar irradiance for the four cities for whole year (February 1st, 2012 - January 31st, 2013)

From Eq. (2.2) it can be seen that for c-Si-based PV cells more power is obtained at lower temperature with higher irradiance. In case of a-Si:H PV/T the effect of temperature and light intensity is more complicated as long time light exposure causes degradation and thermal annealing improves device performance by reducing defect states. As the exponential component of Eq. (2.3) represents the light induced degraded power therefore deriving a suitable dispatch strategy for a-Si:H PV/T will depend on the $\mathrm{PV} / \mathrm{T}$ panel temperature, solar irradiance and peak sun hour period of a day. While taking into account the effects of SWE and annealing altogether the exponential component is required to be modified as a function of these parameters which requires further study. In order to determine the annealing effect a set of binary arrays were generated, which take into account the effects of dispatch strategies on hourly power generation. The binary values of these arrays were set based on specific dispatch strategies. The total energy generation over a year for the chosen cities for different operating temperature (i.e. $25^{\circ} \mathrm{C}$, $50{ }^{\circ} \mathrm{C}$ and $90{ }^{\circ} \mathrm{C}$ ) which were obtained by using the hourly recorded standard solar irradiation data. A time period of 8784 hours (i.e. one year) with both 1 sun and normal sun solar irradiation was considered during the execution of the dispatch strategies. The total energy generated for each case over a year was determined to identify the most effective dispatch strategy for chosen geographical locations. 


\section{CHAPTER REFERENCES}

[1] Anderson AJ. Photovoltaic translation equations: a new approach. Final subcontract report, NREL Technical Report \# NREL/TP-411-20279, 1996 Jan 01, doi:10.2172/177401.

[2] Pathak MJM, Pearce JM, Harrison SJ. Effects on amorphous silicon photovoltaic performance from high-temperature annealing pulses in photovoltaic thermal hybrid devices. Solar Energy Mater Solar Cells 2012;100:199-203. http://dx.doi.org/10.1016/j.solmat.2012.01.015.

[3] King DL, Kratochvil JA, Boyson WE. Temperature coefficients for PV modules and arrays: measurement methods, difficulties, and results. In: 26th IEEE Photovoltaic Specialists Conference Proceedings; 1997. pp. 1183-6. doi:10.1109/PVSC.1997.654300.

[4] Shima M, Isomura M, Wakisaka K, Murata K, Tanaka M. The influence of operation temperature on the output properties of amorphous silicon-related solar cells. Solar Energy Mater Solar Cells 2005;85:167-75. http://dx.doi.org/10.1016/j.solmat.2004.04.016.

[5] Yang L, Chen L. Thickness dependence of light induced degradation in a-Si:H solar cells. J Non-Cryst Solids 1991;137e138:1189-92. http://dx.doi.org/10.1016/S00223093(05)80336-9.

[6] AgriMet. The Pacific Northwest Cooperative Agricultural Weather Network, Bureau of Reclamation. <http://www.usbr.gov/pn/agrimet/>; 2013.

[7] Western Regional Climate Center e Desert Research Institute e Reno, Nevada. $<$ http://www.wrcc.dri.edu/weather/index.html>; 2013. 


\section{CHAPTER 3}

\section{Results: Ideal Cases}

\subsection{1-Sun Simulation ${ }^{\dagger}$}

At higher temperatures a-Si:H-based solar cells degrade more rapidly initially, but stabilize at a higher power than when operated at lower temperatures [1]. Based on this knowledge, the available data, and temperature guided solar cell degradation principles a suitable equation is proposed which can approximately represent the experimental data. The curve fits for this approximation are shown in Fig. 2.2, which represents the simulation output of dispatch strategy Case I (the control case). The study of Case II calculates the total energy generation over a year for the chosen cities for different operating temperature (i.e. $25{ }^{\circ} \mathrm{C}, 50{ }^{\circ} \mathrm{C}$ and $90{ }^{\circ} \mathrm{C}$ ) which were obtained by using the hourly recorded standard solar irradiation data. A time period of 8784 h (i.e. one year) with both 1 sun and normal sun solar irradiation was considered during the execution of the dispatch strategies explained in Case III to Case IX. The maximum power generated at different operating temperatures were normalized with respect to the initial maximum power $\left(\right.$ at $\mathrm{t}=0$ ) at reference temperature $25{ }^{\circ} \mathrm{C}$ which has a value of approximately 5.3 $\mathrm{mW}$ for the small test cells. Case-III to Case-IX utilized an annealing operation. Both the values of 1 sun and normal sun energy generation were calculated for each case study.

\footnotetext{
† The material contained in this chapter was previously published in the journal, Renewable Energy, volume 68, pp. 459-465, August 2014.
} 


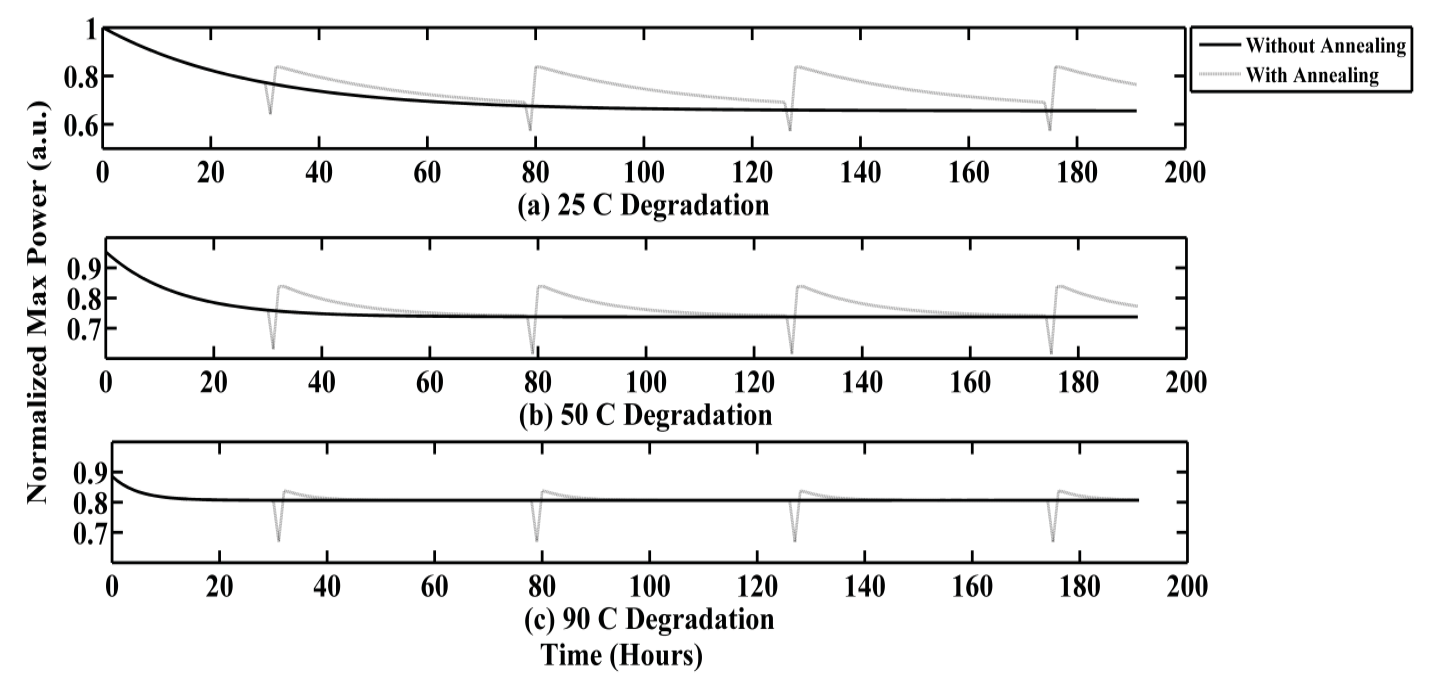

Fig. 3.1: Dispatch strategy Case-III: annealing once every other day, for the operating temperatures. a) $25{ }^{\circ} \mathrm{C}$, b) $50{ }^{\circ} \mathrm{C}$, and c) $90{ }^{\circ} \mathrm{C}$ at 1 sun.

Fig. 3.1 shows the effect of annealing explained in Case III and degradation for the operating temperatures a) $25{ }^{\circ} \mathrm{C}$, b) $50{ }^{\circ} \mathrm{C}$, and c) $90{ }^{\circ} \mathrm{C}$ respectively at 1 sun. In this case annealing is performed (from hour 8 to hour 9) once every two days (after the first day) followed by degradation at a definite operating temperature. Fig. 3.1 shows that the cells generate more power with annealing. As can be seen from Fig. 3.1 at lower temperatures ( $a$ and $b$ ) of operation SWE dominates and reduces electrical output as expected. In Fig. 3.1c, operating at $90{ }^{\circ} \mathrm{C}$ there is very little observable SWE as compared to the lower temperature cases. 


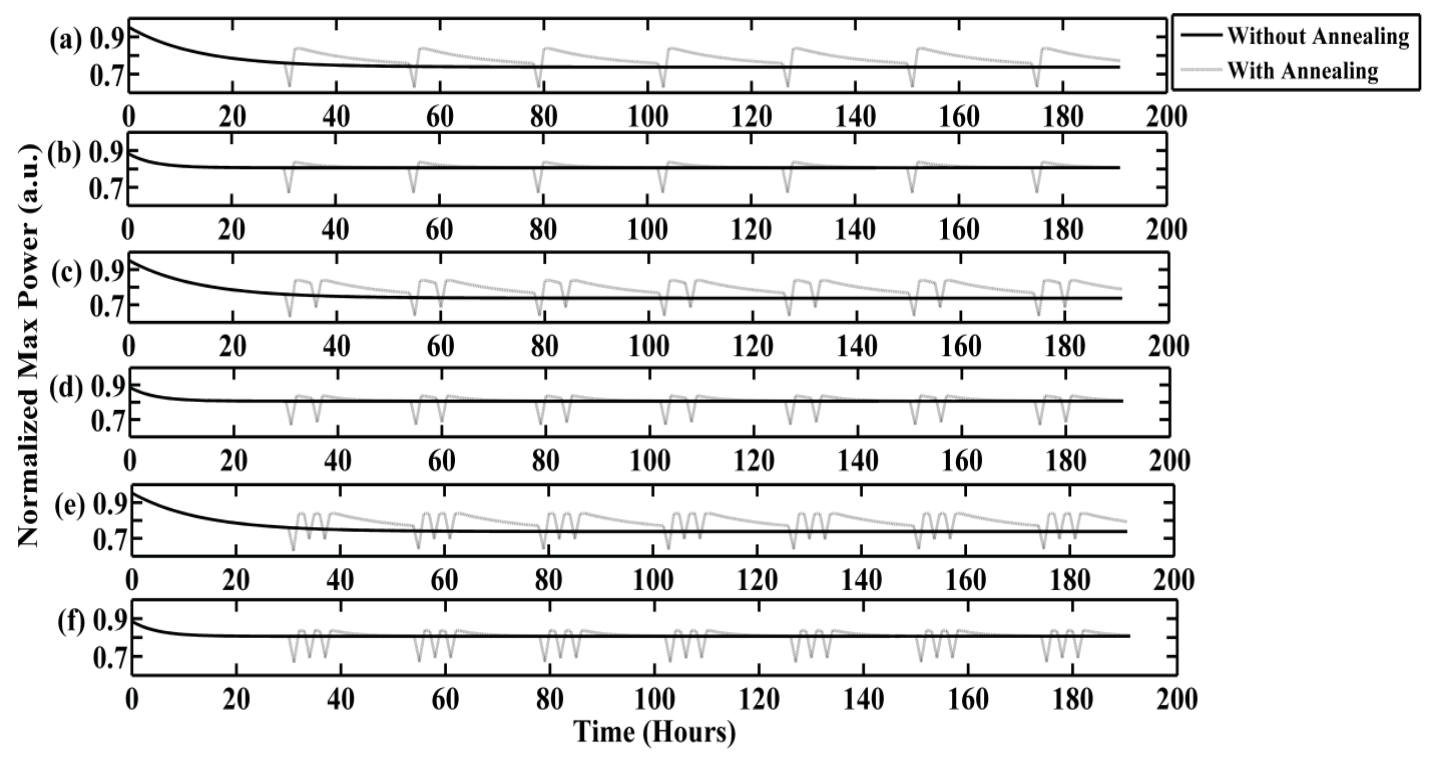

Fig. 3.2: Dispatch strategies consisting of Case-IV: annealing once every day, under 1 sun, a) $50{ }^{\circ} \mathrm{C}$ degradation and b) $90{ }^{\circ} \mathrm{C}$ degradation. Dispatch Strategy Case-IV: annealing twice every day, under 1 sun, c) $50{ }^{\circ} \mathrm{C}$ and d) $90{ }^{\circ} \mathrm{C}$ degradation. Dispatch Strategy Case-VI: annealing three times every day, under 1 sun, e) $50{ }^{\circ} \mathrm{C}$ and f) $90{ }^{\circ} \mathrm{C}$ degradation.

Fig. 3.2 shows the dispatch strategies individually for clarity. Fig. 3.2 shows the 1 sun simulation results obtained for Case IV at operating temperatures a) $50{ }^{\circ} \mathrm{C}$ and b) $90{ }^{\circ} \mathrm{C}$. The annealing is performed once every day (from 800 to $900 \mathrm{~h}$ ) followed by a $50{ }^{\circ} \mathrm{C}$, and $90{ }^{\circ} \mathrm{C}$ degradation, resulted in greater output than the previous case.

The 1 sun simulation results for Case $\mathrm{V}$ at operating temperature $50{ }^{\circ} \mathrm{C}$ and $90{ }^{\circ} \mathrm{C}$ are shown in Fig. 3.2c and d, respectfully. Annealing is performed twice every day. The interval between two consecutive annealing periods is four hours. Between the annealing cycles a degradation temperature of $50{ }^{\circ} \mathrm{C}$ and $90{ }^{\circ} \mathrm{C}$ is maintained respectively.

Fig. 3.2e and f shows simulation results for Case VI. Annealing is performed three times a day with an interval of two hours. During the intervals a degradation temperature of $50{ }^{\circ} \mathrm{C}(\mathrm{e})$ and $90{ }^{\circ} \mathrm{C}(\mathrm{f})$ is maintained respectively. 


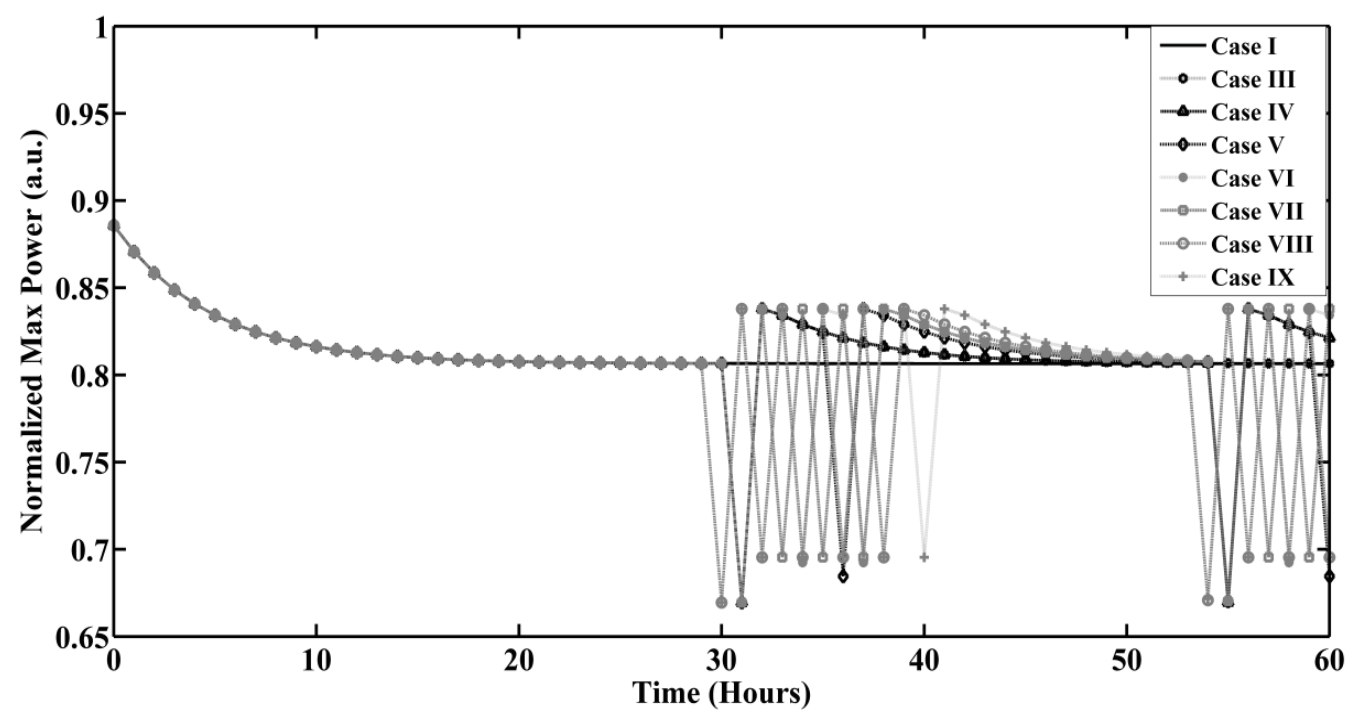

Fig. 3.3: Hourly maximum output power for different dispatch strategies under 1 sun (operating temperature $90{ }^{\circ} \mathrm{C}$ ).

Similar plots were obtained for case studies VII, VIII, and IX. In all these cases simulations were performed for operating temperatures $25{ }^{\circ} \mathrm{C}, 50{ }^{\circ} \mathrm{C}$, and $90{ }^{\circ} \mathrm{C}$. Finally, area analysis was performed to determine the total energy generated in each cases. Fig. 3.3 shows the hourly maximum output power for different case studies at 1 sun and operating temperature $90{ }^{\circ} \mathrm{C}$.

\subsection{Simulation Based on Real Time Hourly Solar Irradiance Data}

Unlike the 1-sun irradiation, in the outdoor environment the solar irradiance varies frequently. This affects the performance of any solar cell tremendously and when annealing is associated the power generation over a day also fluctuates depending on the applied dispatch strategy. To see how the dispatch strategies influence power throughout the day Fig. 3.4 is used as an example and shows the average hourly power generation in San Antonio for different dispatch strategies. As can be seen in Fig. 3.4, the power curves closely follow the solar irradiance curve shown on the right y-axis. 


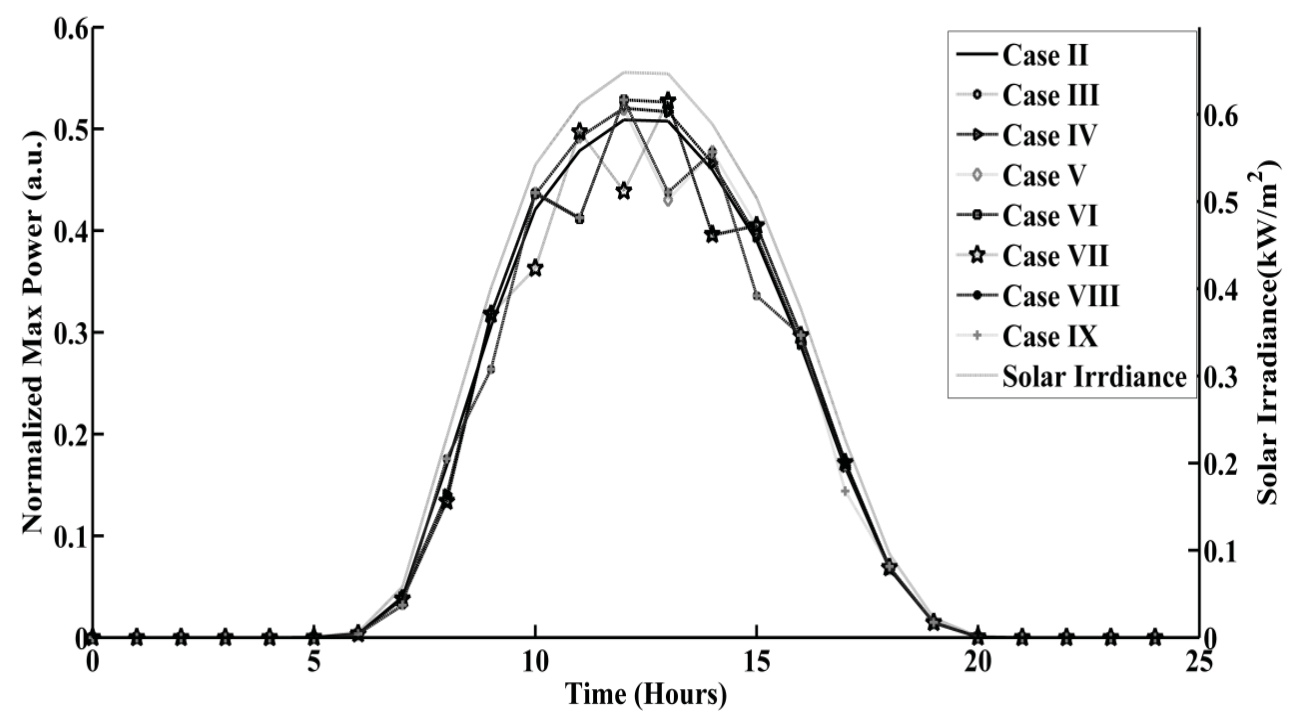

Fig. 3.4 Average hourly power generation in San Antonio for different case studies. Right Y-axis shows average hourly solar irradiance.

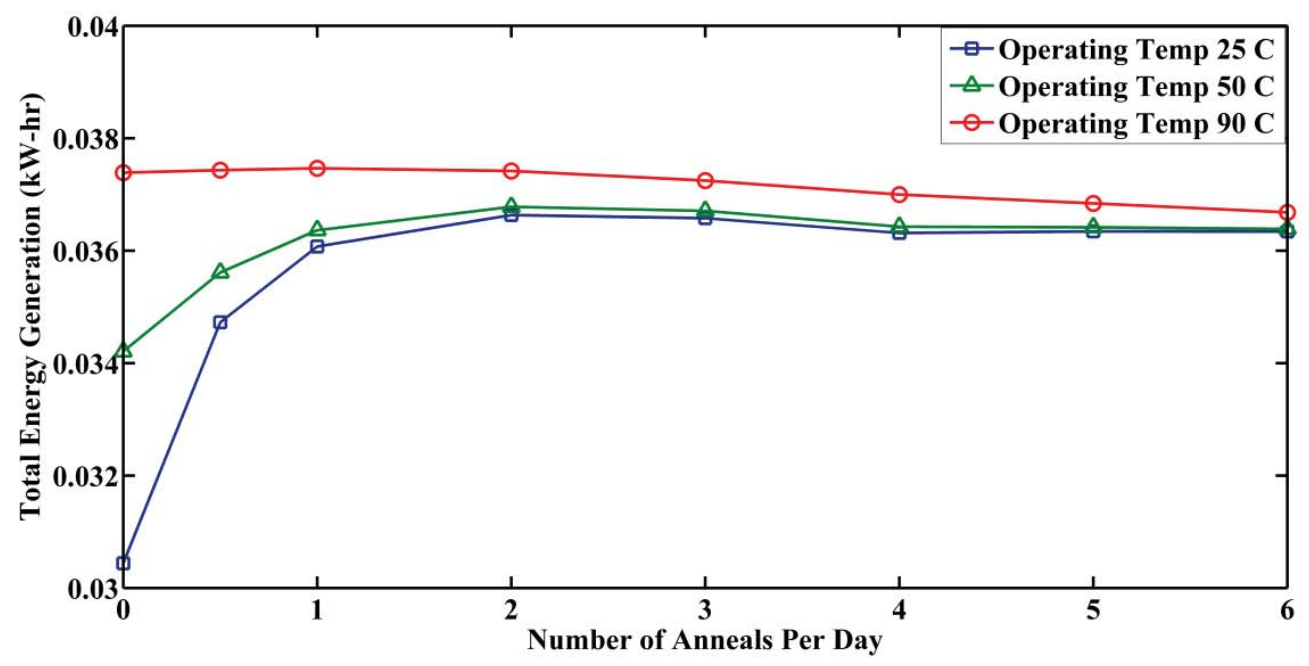

Fig. 3.5 Total energy generation (at operating temperature $25{ }^{\circ} \mathrm{C}, 50{ }^{\circ} \mathrm{C}$, and $90{ }^{\circ} \mathrm{C}$ under 1 sun) over a time period of 8784 hours as a function of the number of anneals per day.

Fig. 3.5 shows the total energy generation over a period of 8784 hours (under 1 sun and at different operating temperatures) with respect to the number of anneals per day. It 
is notable that at operating temperature $90{ }^{\circ} \mathrm{C}$ and 1 sun irradiance, the energy is maximized for the dispatch strategy of Case IV (annealing once per day). Beyond that at 1 sun irradiance, with increasing the number of anneals per day total energy generation decreases and even drops to lower values than the DSS energy. This can be attributed to the power drop during the annealing cycle. If too much of the day is spent annealing then there is not enough time to capture and convert radiation at the higher efficiencies. Also it is noteworthy that at operating temperatures $25^{\circ} \mathrm{C}$ and $50{ }^{\circ} \mathrm{C}$ the energy generation is not maximized for the strategy of Case IV. Instead, the energy is highest for Case V (annealing twice a day), which can be attributed to the fact that degradation is more pronounced at lower temperatures and the increased number of annealing cycles per day compensates for the loss.

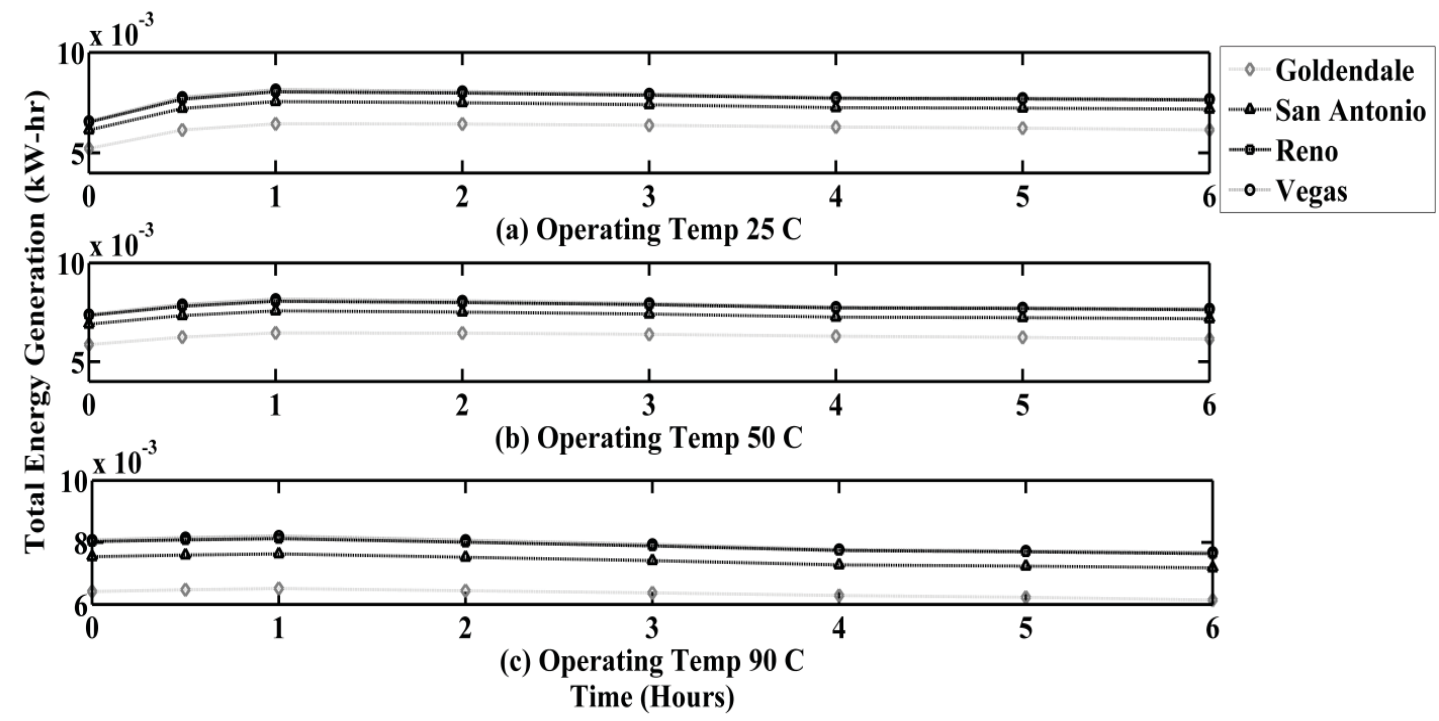

Fig. 3.6 Total energy generation under normal sun at operating temperature for a) 25 ${ }^{\circ} \mathrm{C}$, b) $50{ }^{\circ} \mathrm{C}$, and c) $90{ }^{\circ} \mathrm{C}$ the four cities over a year with change in number of anneals per day

Fig. 3.6 shows the total energy generation over a year (under normal sun for operating temperatures) for a) $25{ }^{\circ} \mathrm{C}$, b) $50{ }^{\circ} \mathrm{C}$, and c) $90{ }^{\circ} \mathrm{C}$ for the four locations as a function of the number of anneals per day. Annealing once per day generated the maximum power. The lower values of energy than the 1 sun cases can be attributed to the reduced total flux 
as compared to constant 1 sun illumination. These results show that annealing once a day is sufficient to maximize electrical energy generation using spike annealing in a-Si:H PVT.

Table 3.1: Total energy generation over a year for the four cities for different case studies

\begin{tabular}{|c|c|c|c|c|c|}
\hline Case Study & $\begin{array}{l}\text { Operating } \\
\text { Temperature }\end{array}$ & $\begin{array}{l}\text { Goldendale } \\
(\mathrm{mW}-\mathbf{h r})\end{array}$ & $\begin{array}{l}\text { San Antonio } \\
(\mathrm{mW}-\mathbf{h r})\end{array}$ & $\operatorname{Reno}(\mathrm{mW}$-hr) & \begin{tabular}{|l|} 
Las Vegas \\
$(\mathrm{mW}-\mathrm{hr})$
\end{tabular} \\
\hline \multirow[t]{3}{*}{ Case-II } & $25^{\circ} \mathrm{C}$ & 1 & 1 & 1 & 1 \\
\hline & $50^{\circ} \mathrm{C}$ & 1 & 1 & 1 & 1 \\
\hline & $90^{\circ} \mathrm{C}$ & 1 & 1 & 1 & 1 \\
\hline \multirow[t]{3}{*}{ Case-III } & $25^{\circ} \mathrm{C}$ & 1.176 & 1.175 & 1.175 & 1.182 \\
\hline & $50^{\circ} \mathrm{C}$ & 1.064 & 1.063 & 1.063 & 1.068 \\
\hline & $90^{\circ} \mathrm{C}$ & 1.009 & 1.007 & 1.007 & 1.009 \\
\hline \multirow[t]{3}{*}{ Case-IV } & $25^{\circ} \mathrm{C}$ & 1.235 & 1.231 & 1.23 & 1.24 \\
\hline & $50^{\circ} \mathrm{C}$ & 1.1 & 1.098 & 1.097 & 1.105 \\
\hline & $90^{\circ} \mathrm{C}$ & 1.015 & 1.012 & 1.012 & 1.016 \\
\hline \multirow[t]{3}{*}{ Case- V } & $25^{\circ} \mathrm{C}$ & 1.233 & 1.222 & 1.221 & 1.226 \\
\hline & $50^{\circ} \mathrm{C}$ & 1.098 & 1.089 & 1.089 & 1.093 \\
\hline & $90^{\circ} \mathrm{C}$ & 1.004 & 0.997 & 0.997 & 0.999 \\
\hline \multirow[t]{3}{*}{ Case-VI } & $25^{\circ} \mathrm{C}$ & 1.221 & 1.205 & 1.205 & 1.207 \\
\hline & $50^{\circ} \mathrm{C}$ & 1.088 & 1.075 & 1.074 & 1.076 \\
\hline & $90^{\circ} \mathrm{C}$ & 0.993 & 0.983 & 0.982 & 0.983 \\
\hline \multirow[t]{3}{*}{ Case-VII } & $25^{\circ} \mathrm{C}$ & 1.204 & 1.182 & 1.181 & 1.181 \\
\hline & $50^{\circ} \mathrm{C}$ & 1.072 & 1.052 & 1.051 & 1.051 \\
\hline & $90^{\circ} \mathrm{C}$ & 0.98 & 0.964 & 0.964 & 0.962 \\
\hline \multirow[t]{3}{*}{ Case-VIII } & $25^{\circ} \mathrm{C}$ & 1.194 & 1.178 & 1.177 & 1.176 \\
\hline & $50^{\circ} \mathrm{C}$ & 1.062 & 1.048 & 1.047 & 1.046 \\
\hline & $90^{\circ} \mathrm{C}$ & 0.971 & 0.959 & 0.959 & 0.957 \\
\hline
\end{tabular}




\begin{tabular}{|l|l|l|l|l|l|}
\hline Case-IX & $25^{\circ} \mathrm{C}$ & 1.177 & 1.169 & 1.168 & 1.169 \\
\cline { 2 - 6 } & $50^{\circ} \mathrm{C}$ & 1.047 & 1.04 & 1.039 & 1.039 \\
\cline { 2 - 6 } & $90{ }^{\circ} \mathrm{C}$ & 0.957 & 0.952 & 0.951 & 0.951 \\
\hline
\end{tabular}

Table 3.1 shows the simulated normalized energy generation over a year for the four cities. All the values were normalized with respect to the no annealing energy generation at corresponding operating temperatures. Case Study-IV (annealing once per day) was found to be the most effective dispatch strategy; resulting in more than $23 \%, 10 \%$, and $1.2 \%$ additional energy generation over a year for the operating temperatures $25{ }^{\circ} \mathrm{C}, 50$ ${ }^{\circ} \mathrm{C}$, and $90{ }^{\circ} \mathrm{C}$ respectively while the total energy generation is maximum for operating temperature $90{ }^{\circ} \mathrm{C}$. These values are in agreement with past work [2] that predicted about a $10 \%$ improvement using only 1 sun degradation and daily spike anneals at $50{ }^{\circ} \mathrm{C}$. The results also underscore the importance of using real temperatures and not STC in the optimization of PV devices. Although, using Case IV at $25{ }^{\circ} \mathrm{C}$ showed more than a $23 \%$ increase in output in most locations the operating temperatures for PV are much higher. It is also clear that running a-Si:H PV/T at high temperatures (e.g. $90{ }^{\circ} \mathrm{C}$ ) negated the majority of the spike annealing benefit gaining only about $1 \%$. At all temperatures, one time annealing per day during peak sun hours is sufficient to generate maximum power in all of the geographic locations simulated. Geographic location (at least within the contiguous United States) does not appear to be an important variable for determining the optimum dispatch strategy for the electrical output of spike annealing a-Si:H PV/T devices as the range in solar flux was not enough to appreciably effect the dispatch strategy for annealing. In general the operating temperature for solar cells can be easily raised to $50{ }^{\circ} \mathrm{C}$, but using the thermal collector it is possible to maintain a steady temperature of $90{ }^{\circ} \mathrm{C}$ which provides even higher energy.

Now that a suitable dispatch strategy has been developed future work is needed to determine the degradation characteristics at temperatures other than $25{ }^{\circ} \mathrm{C}, 50{ }^{\circ} \mathrm{C}$, and 90 ${ }^{\circ} \mathrm{C}$. Using Eq. (2.3) it is possible to obtain the degradation traits at other temperatures, but the problem lies on determining the accurate values of the parameters $k_{d s s}$ and $u_{d s s}$ as 
these parameters are functions of the $\mathrm{PV} / \mathrm{T}$ temperature. In such a case the values can be approximated (e.g. if at temperatures $T_{1}$ and $T_{2}\left(T_{1}<T_{2}\right)$ the values of parameter $k_{d s s}$ are $k_{d s s 1}$ and $k_{d s s 2}$ respectively, then at a temperature $T_{x}$ such that $T_{1}<T_{x}<T_{2}$ the value of $k_{d s s}$ ) using:

$$
k_{d s s x}=k_{d s s 1}+\frac{\left(k_{d s s 2}-k_{d s s 1}\right)}{\left(T_{2}-T_{1}\right)} \times\left(T_{x}-T_{1}\right)
$$

Similarly the equation for getting $u_{d s s x}$ is following,

$$
u_{d s s x}=u_{d s s 1}+\frac{\left(u_{d s s 2}-u_{d s s 1}\right)}{\left(T_{2}-T_{1}\right)} \times\left(T_{x}-T_{1}\right)
$$

Using Eqs. (3.1) and (3.2) it is possible to determine the approximate values of $k_{d s s}$ and $u_{d s s}$ for an arbitrary operating temperature. Future research can focus on experiments that could help reduce the error associated with this approximation by using actual field temperatures. In addition, the positive results found in the simulations, indicate that future work should be undertaken to verify the energy gains using a-Si:H PV/T with daily annealing pulses and to find the optimal operating temperature to maximize electrical output. Finally, further work is necessary to maximize the total exergy of the system [3], by considering the effects of annealing pulses on the thermal energy recovered from the $\mathrm{PV} / \mathrm{T}$ and a final optimal dispatch strategy can be determined taking into account load data for a specific application and location.

In general the outdoor temperature varies frequently over a day hence the above mentioned equations can be used in approximately determining the values of the parameters $k_{d s s}$ and $u_{d s s}$ with temperature change. This will eventually take into account the effect of temperature on solar power generation using PV/T. Chapter 4 portrays the impact of varying temperature on $\mathrm{PV} / \mathrm{T}$ performance thoroughly. The dispatch mechanism in real world scenario is also analyzed in this chapter. 


\section{CHAPTER REFERENCES}

[1] Pathak MJM, Girotra K, Harrison SJ, Pearce JM. The effect of hybrid photovoltaic thermal device operating conditions on intrinsic layer thickness optimization of hydrogenated amorphous silicon solar cells. Solar Energy 2012;86:2673-7. http://dx.doi.org/10.1016/j.solener.2012.06.002.

[2] Pathak MJM, Pearce JM, Harrison SJ. Effects on amorphous silicon photovoltaic performance from high-temperature annealing pulses in photovoltaic thermal hybrid devices. Solar Energy Mater Solar Cells 2012;100:199-203. http://dx.doi.org/10.1016/j.solmat.2012.01.015.

[3] Pathak MJM, Sanders PG, Pearce JM. Optimizing limited solar roof access by exergy analysis of solar thermal, photovoltaic, and hybrid photovoltaic thermal systems. Applied Energy 2014;120:115-24. http://dx.doi.org/10.1016/j.apenergy.2014.01.041. 


\section{CHAPTER 4}

\section{Results: Outdoor Temperature Simulation}

The preceding chapters focused on the hybrid amorphous silicon solar photovoltaic thermal (PVT) system behavior associated with annealing of defect states in the PV absorber and corresponding dispatch strategies under sustained operating temperatures, showed that the degradation associated parameters varies with the operating temperature. To provide analysis for real-world conditions over which the temperature can fluctuate significantly, the effect of temperature has been incorporated in the updated model. By considering the degradation associated parameters as functions of temperature differential increment/decrement calculation is used to obtain the values of these parameters for the intermediate temperatures between $25{ }^{\circ} \mathrm{C}$ and $90{ }^{\circ} \mathrm{C}$ - thus making the parameters function of temperature. In addition, the annealing associated PVT performance in real world outdoor environment scenario- where the temperature and solar irradiance varies frequently has been studied in detail.

\subsection{Background}

\subsubsection{Degradation Associated Parameters}

Previous chapter has introduced the parameters $k_{d s s}$ and $u_{d s s}$ [1] also referred as the degradation associated parameter plays a major role in rendering the degradation phenomenon. These parameters were introduced in the max power generation equation in order to modify the equation for PV/T and incorporate the effect of SWE in it [1]. It is really important to understand how their values change with temperature.

‡ The material contained in this chapter has been submitted to the journal, Renewable Energy. 
Exponential fits [1] to experimental data (Figure 2.2) showing degenerated steady state obtained at sustained operating temperatures $25{ }^{\circ} \mathrm{C}, 50{ }^{\circ} \mathrm{C}$, and $90{ }^{\circ} \mathrm{C}$ y for a-Si: $\mathrm{H}$ PV cell active layer thickness of $630 \mathrm{~nm}$ under 1 sun (source: Pathak et. al.) [2] were used to derive $k_{d s s}$ and $u_{d s s}$.

When the irradiance is constant, it is notable that the exponential degradation rate and the final degenerative steady state power generation both depend on the operating temperature. To take into account the effect of operating temperature outside of fixed values the degradation rate and the steady state power generation is required to make a function of temperature. In other words, the degradation associated parameters $k_{d s s}$ and $u_{d s s}$ should be represented as a function of temperature. The parameter $k_{d s s}$ explains the degenerative steady state and $u_{d s s}$ justifies the degradation rate. It has also been observed that $k_{d s s}$ decreases and $u_{d s s}$ increases with temperature rise. Another remarkable observation is that at higher temperature power generation reaches steady state with a faster degradation rate (requires less time) while it is opposite for the lower temperature cases. Also steady state power generation is higher at higher temperatures. Equation (3.1) and (3.2) linearly calculate the values of these parameters in the intermediate regions between $25{ }^{\circ} \mathrm{C}$ to $50{ }^{\circ} \mathrm{C}$ and $50{ }^{\circ} \mathrm{C}$ to $90{ }^{\circ} \mathrm{C}$ [1]. Figure 4.1 and 4.2 shows the corresponding plots.

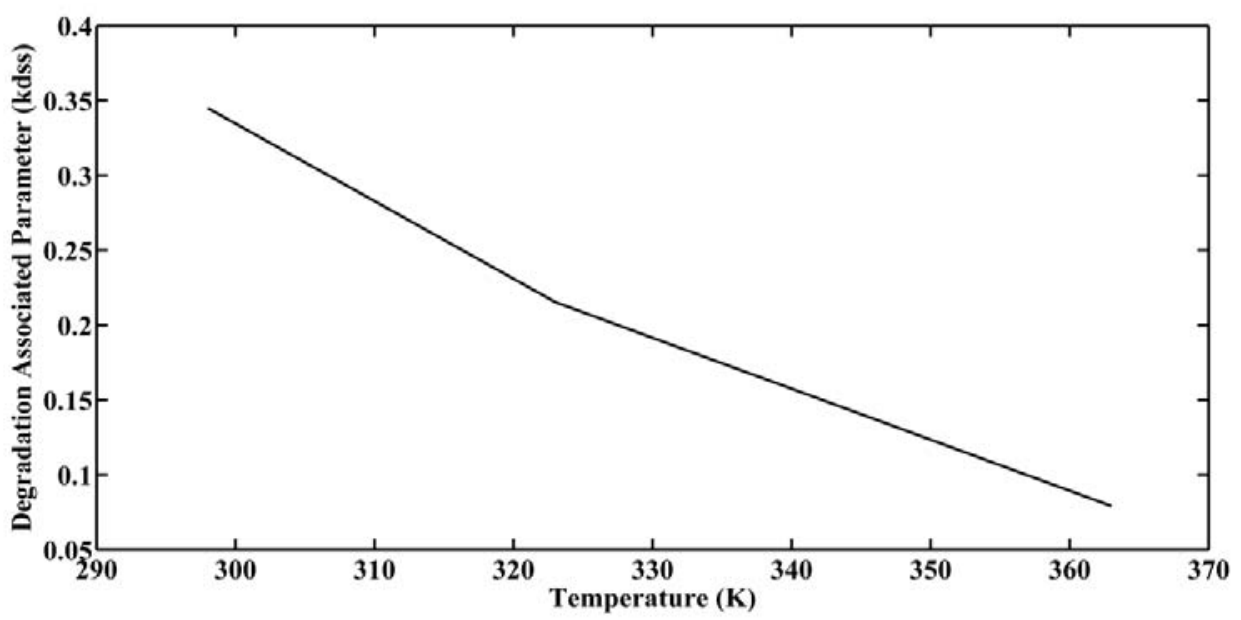

Fig. 4.1 Degradation associated parameter $k_{d s s}$ against temperature 


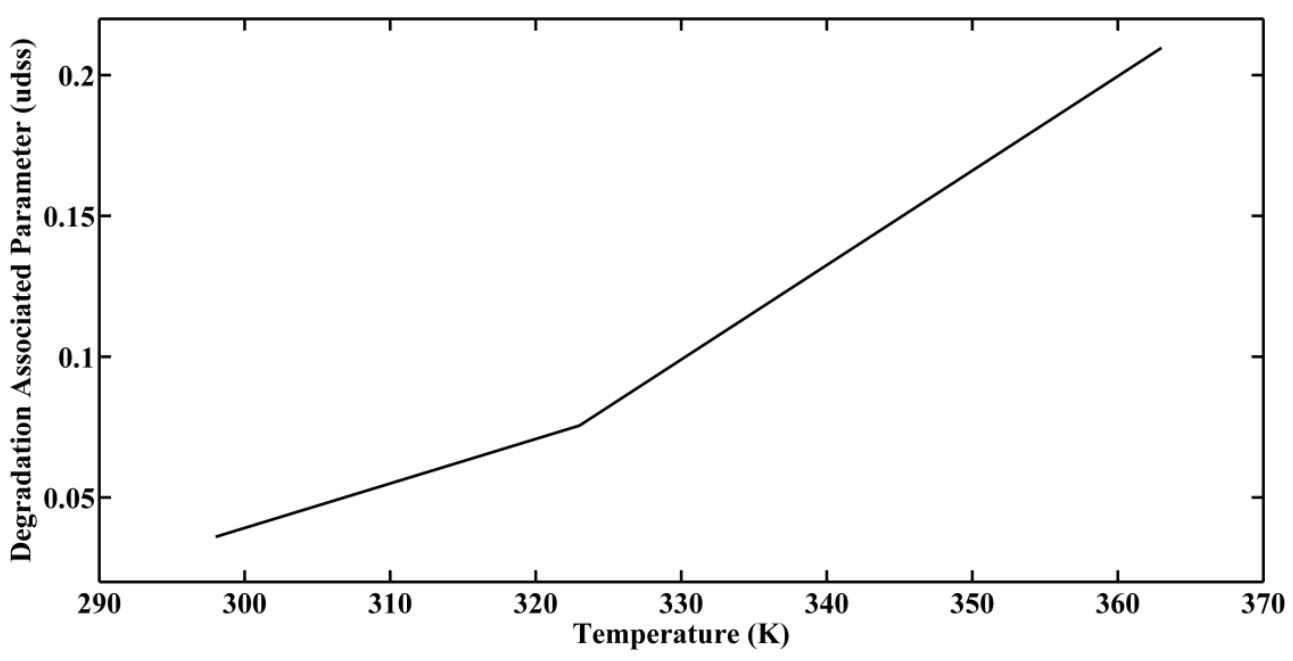

Fig. 4.2 Degradation associated parameter $u_{d s s}$ against temperature

As a first approximation the changes in the parameter values have been considered to be changing linearly in the range between the experimentally measured temperatures. Hence, there exist two linear regions with different slopes in each plot. The value of the parameters outside the range of $25{ }^{\circ} \mathrm{C}$ to $90{ }^{\circ} \mathrm{C}$ is calculated by extending the lines linearly.

\subsection{Methodology}

\subsubsection{Global Expansion and Simulation Mechanism Updates}

Previous simulations were confined to four specific cities in United States [1]. In order to expand the optimization maps for the performance of the $\mathrm{PV} / \mathrm{T}$ it is required to expand the modeling range by including more solar data collected from worldwide solar resources and satellites. As a primary approach in the present work the solar data for regions all over US (including Alaska and Hawaii) and Western Canada has been included in the simulation. Primarily the hourly solar irradiance and temperature data from the U.S. air force weather stations has been used [3, 4]. The NREL Solar Prospector has been utilized as well for collecting the solar data in US using geographic coordinates [5]. The Canadian data was obtained from the National Resources Canada (NRCAN) website [6]. The simulation mechanism is almost similar as before except the fact that the 
user has the freedom to access more data from around all over U.S. and Western Canada. Users can input solar data in the simulation using either known USAF station ID or geographic coordinates and the program gives the exact PV/T output at different operating conditions and dispatch strategies. Also it is notable that the hourly outdoor temperature data has been utilized in the simulation hence the degradation associated parameters $k_{d s s}$ and $u_{d s s}$ fluctuates in accordance with the temperature. The solar data that has been utilized is the METSTAT-modeled global horizontal solar irradiation data [7] which indicates the total amount of direct and diffuse solar radiation (METSTATmodeled) received on a horizontal surface during the 60 -minute period ending at the timestamp.

\subsubsection{Association of Temperature Data for Selected Locations}

For better understanding of the PVT behavior it is required to include the hourly temperature time series data. For a particular location the temperature varies frequently. In the same manner the degradation associated parameters vary hourly. The analysis

utilizes time series temperature data along with the hourly solar irradiance data for four particular locations with different atmospheric condition. These locations were chosen according to the incidence of solar flux and temperature readings. The approach was to include locations with four different atmospheric criteria:

1. High solar flux/high temperature

2. High solar flux/low temperature

3. Low solar flux/high temperature

4. Low solar flux/low temperature

As for the first standard the city of Casa Grande, Arizona was chosen where the flux and temperature is fairly high all through the year. For the second category city of Aspen in Pitkin County, Colorado is chosen where the temperature is very low while the corresponding solar flux is surprisingly high. For the third category city of Apalachicola, 
Florida was chosen where the temperature is very high regardless the fact that the area gets comparatively less solar flux. Finally, city of Anchorage in Alaska was chosen for the fourth category. Here it is to be mentioned that usually the amount of incidence of solar flux depends on the geographic coordinate, incident angle and air mass/optical path of incidence. On the other hand, the temperature mostly depends on the humidity and air mass. In general the average hourly solar flux in Aspen, Colorado $\left(193.83 \mathrm{~W} / \mathrm{m}^{2}\right)$ is lower than Apalachicola, Florida $\left(214.97 \mathrm{~W} / \mathrm{m}^{2}\right)$ but the average hourly temperature in Aspen, Colorado $\left(5.23{ }^{\circ} \mathrm{C}\right)$ is very low regardless the fact they get a decent amount of solar flux. Hence, Aspen has been chosen as a high solar flux/low temperature area. On the other hand the temperature in Apalachicola, Florida $\left(20.4{ }^{\circ} \mathrm{C}\right)$ is remarkably high for a moderate incident flux. Thus Apalachicola is chosen as a low flux/high temperature area. Table 4.1 shows the chosen locations based on flux/ temperature readings.

Table 4.1: Chosen cities based on atmospheric criteria

\begin{tabular}{|l|l|l|}
\hline & High Flux & Low Flux \\
\hline High Temperature & Casa Grande, Arizona & Apalachicola, Florida \\
\hline Low Tempearature & Aspen, Colorado & Anchorage, Alaska \\
\hline
\end{tabular}

Table 4.2 shows the summary of climates for the chosen cities. The time series hourly data sets starting from January $1^{\text {st }}, 2002$ to December $31^{\text {st }}, 2002$ were utilized in the simulation. It is to be noted that the average hourly temperature in this cities are lower than $25{ }^{\circ} \mathrm{C}$ which was the lowest operating temperature in the consistent operating temperature PVT dispatch model.

Table 4.2 Summary of climate of the chosen cities

\begin{tabular}{|l|l|c|l|l|}
\hline City & Coordinates & $\begin{array}{c}\text { Average Hourly } \\
\text { Temperature (for } \\
\text { the year 2002) }\end{array}$ & Altitude & $\begin{array}{c}\text { Average } \\
\text { hourly solar } \\
\text { irradiance } \\
\text { (for the year }\end{array}$ \\
\hline
\end{tabular}




\begin{tabular}{|c|c|c|c|c|}
\hline & & & & 2002) \\
\hline $\begin{array}{c}\text { Anchorage } \\
\text { (Anchorage Borough, } \\
\text { Alaska) }\end{array}$ & $\begin{array}{c}61.2167^{\circ} \mathrm{N}, \\
149.9000^{\circ} \mathrm{W}\end{array}$ & $-3.44598^{\circ} \mathrm{C}$ & $102 \mathrm{ft.}$ & $\begin{array}{c}100.7629 \\
\mathrm{~W} / \mathrm{m}^{2}\end{array}$ \\
\hline $\begin{array}{c}\text { Casa Grande (Pinal } \\
\text { County, Arizona) }\end{array}$ & $\begin{array}{c}32.8858^{\circ} \mathrm{N}, \\
111.7439^{\circ} \mathrm{W}\end{array}$ & $21.59384^{\circ} \mathrm{C}$ & $1,398 \mathrm{ft}$. & $\begin{array}{c}251.3572 \\
\mathrm{~W} / \mathrm{m}^{2}\end{array}$ \\
\hline $\begin{array}{c}\text { Apalachicola } \\
\text { (Franklin County, } \\
\text { Florida) }\end{array}$ & $\begin{array}{c}29.7253^{\circ} \mathrm{N}, \\
84.9925^{\circ} \mathrm{W}\end{array}$ & $20.39634^{\circ} \mathrm{C}$ & $13 \mathrm{ft.}$ & $\begin{array}{c}214.9726 \\
\mathrm{~W} / \mathrm{m}^{2}\end{array}$ \\
\hline $\begin{array}{c}\text { Aspen (Pitkin County, } \\
\text { Colorado) }\end{array}$ & $\begin{array}{c}39.1922^{\circ} \mathrm{N}, \\
106.8244^{\circ} \mathrm{W}\end{array}$ & $5.232163{ }^{\circ} \mathrm{C}$ & $7,890 \mathrm{ft.}$ & $\begin{array}{c}193.8292 \\
\mathrm{~W} / \mathrm{m}^{2}\end{array}$ \\
\hline
\end{tabular}

Figure 4.3 and 4.4 shows the daily average solar flux and the temperature reading in the four chosen cities. Average solar irradiance per day for the cities (Anchorage, Casa Grande, Apalachicola, and Aspen) are 2.42, 6.03, 5.16, and 4.65 sun hours respectively. The peak sun hour with high flux lies in between 900 to $1600 \mathrm{hrs}$ when the flux is higher than $250 \mathrm{~W} / \mathrm{m}^{2}$. Also it is noteworthy that during these hours the temperature is comparatively low which means the degradation occurs at a slow rate.

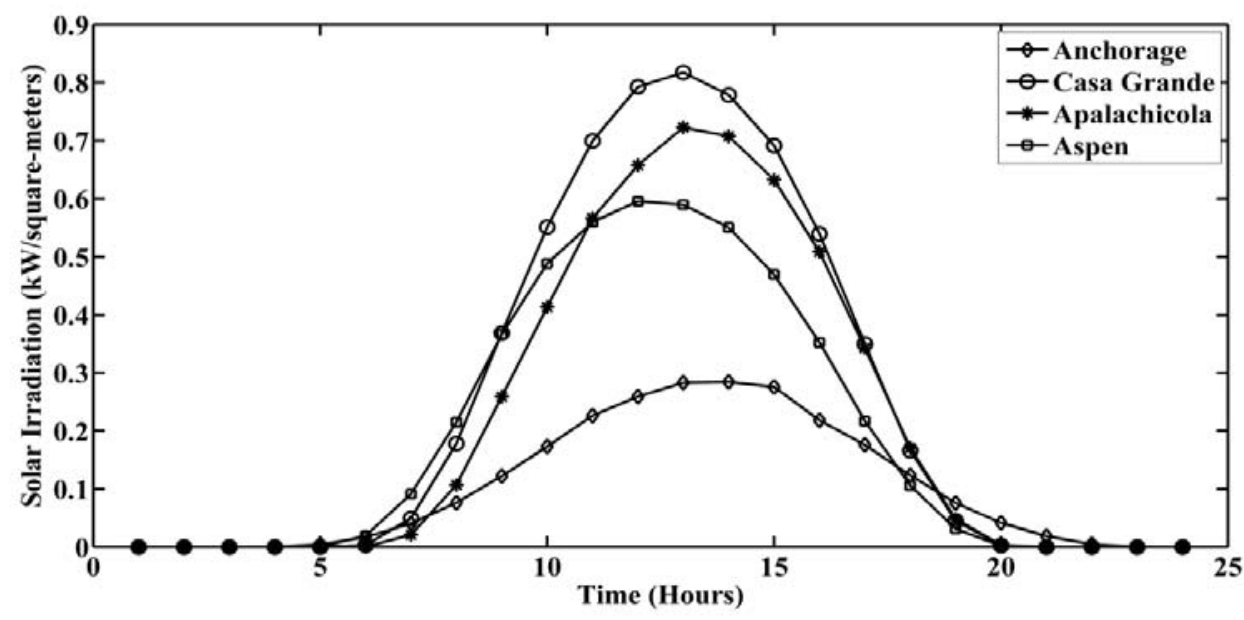

Fig 4.3 Average hourly solar irradiation per day for the four cities 


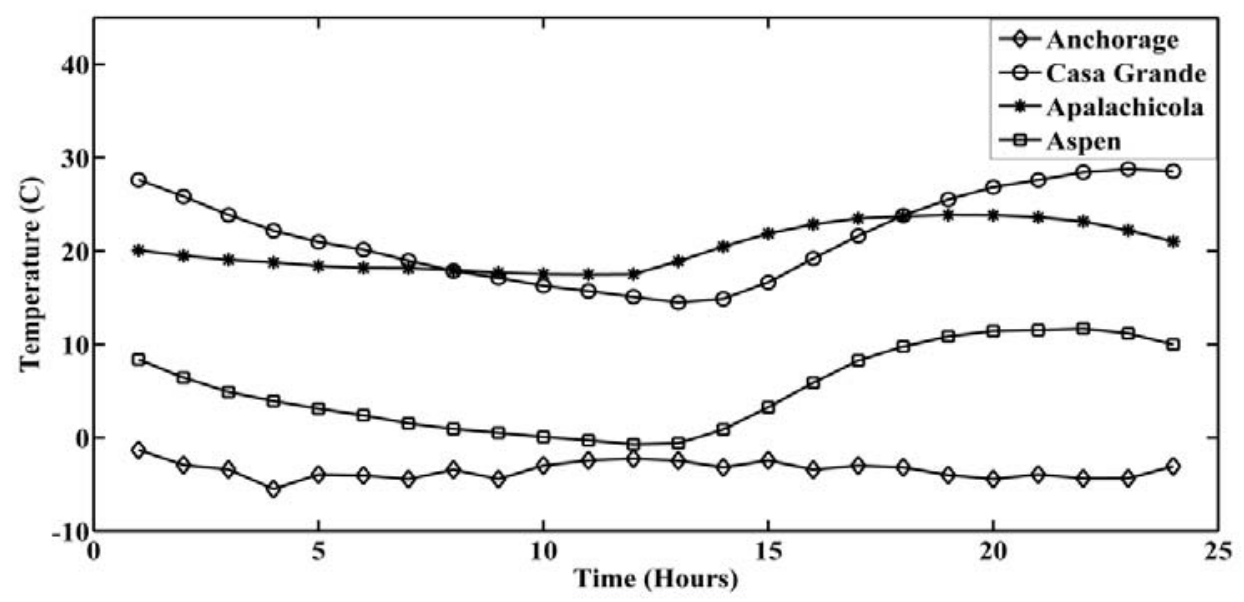

Fig. 4.4 Average hourly temperature readings per day for the four cities

\subsection{Results}

\subsubsection{Simulation at Sustained Operating Temperature}

As an initial step of the analysis the simulation was performed at sustained operating temperatures where the degradation parameters are constant. Figure 4.5, 4.6, 4.7 and 4.8 shows the output obtained for the sustained operating temperature simulation in the four representative cities. In all the cases the $90{ }^{\circ} \mathrm{C}$ operating temperature with 1 time annealing per day provides the maximum power output.

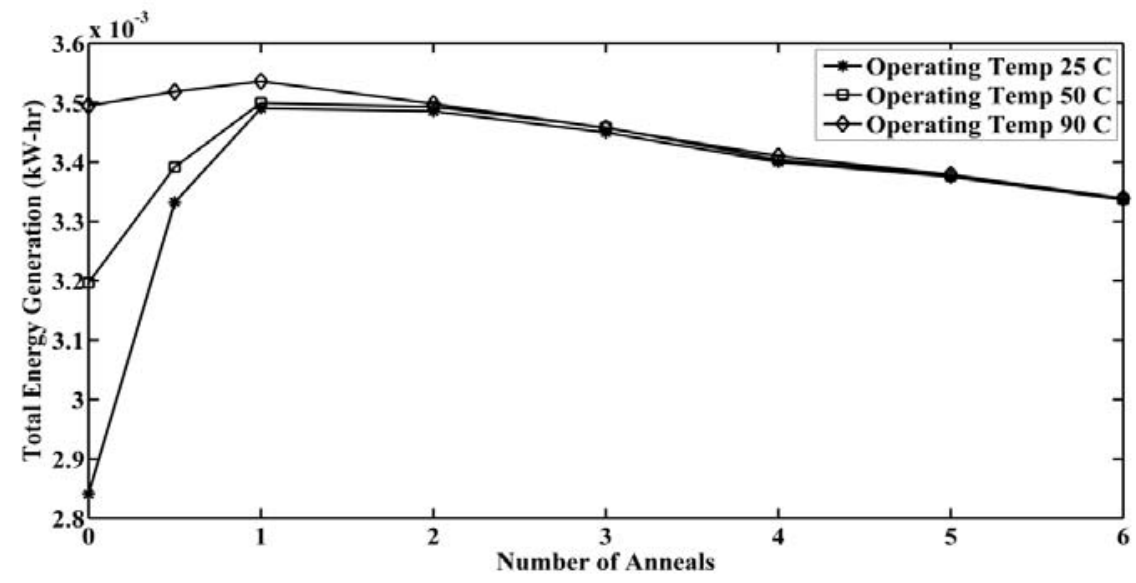

Fig. 4.5 Total electrical energy generation over a year under different annealing conditions in Anchorage, $\mathrm{AK}$ at sustained operating temperatures 


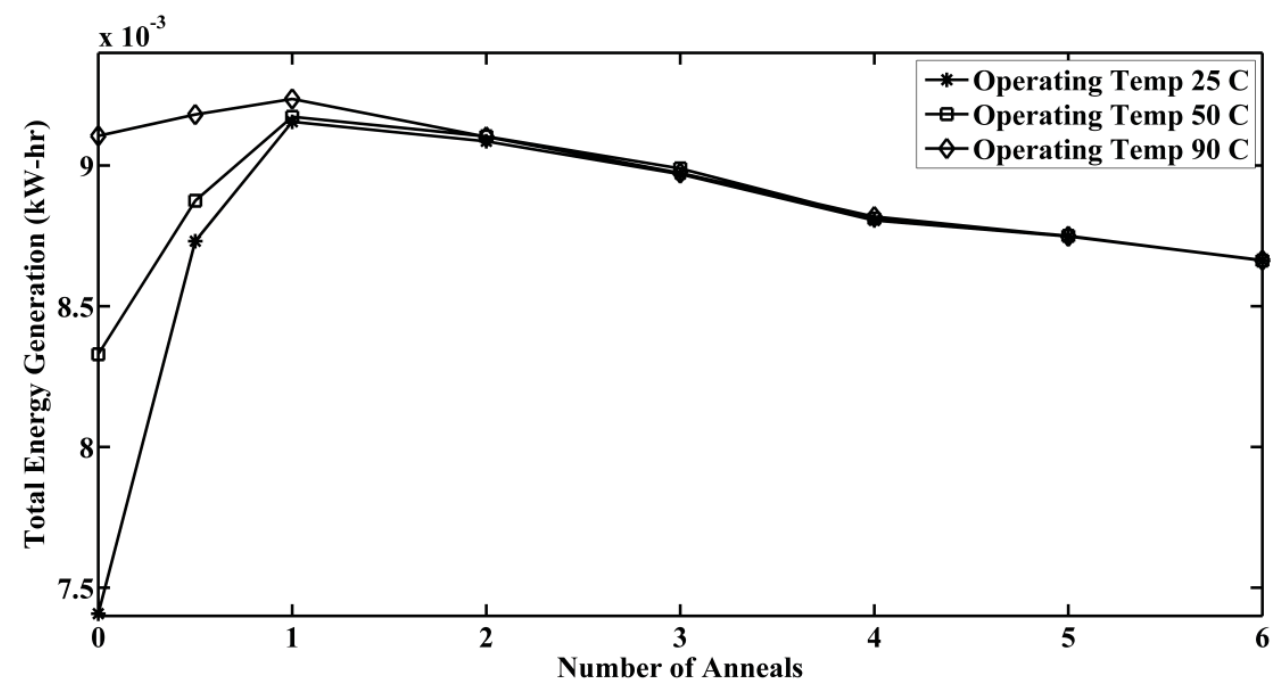

Fig. 4.6 Total electrical energy generation over a year under different annealing conditions in Casa Grande, $\mathrm{AZ}$ at sustained operating temperatures

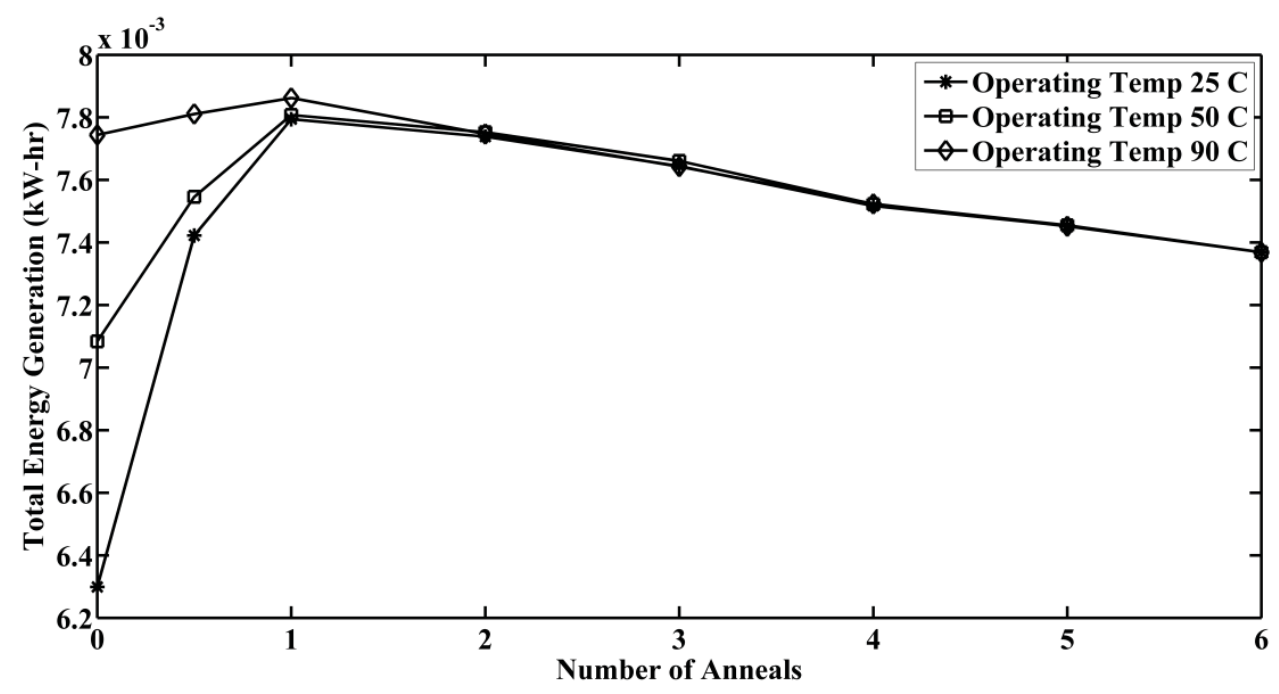

Fig. 4.7 Total electrical energy generation over a year under different annealing conditions in Apalachicola, FL at sustained operating temperatures 


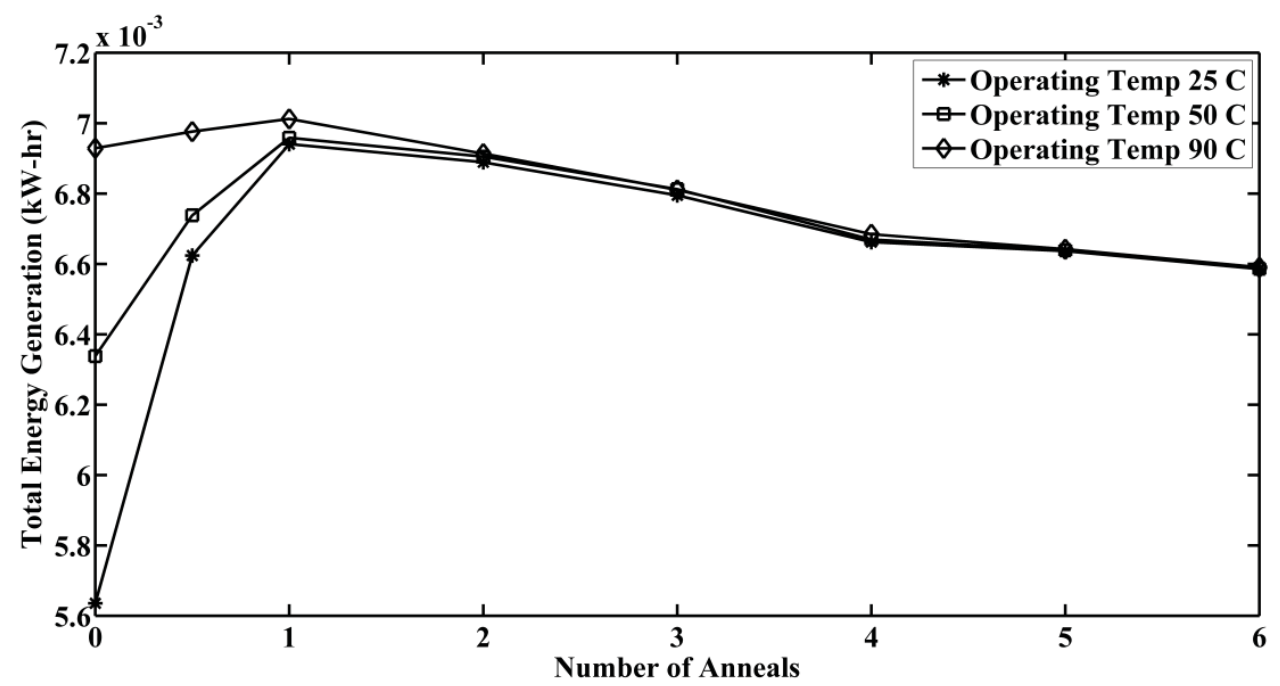

Fig. 4.8 Total electrical energy generation over a year under different annealing conditions in Aspen, $\mathrm{CO}$ at sustained operating temperatures

Figure 4.9 shows the maximum electrical energy generation for the four cities at sustained operating temperatures. Table 4.3 shows the normalized max energy obtained for the sustained operating temperature cases.

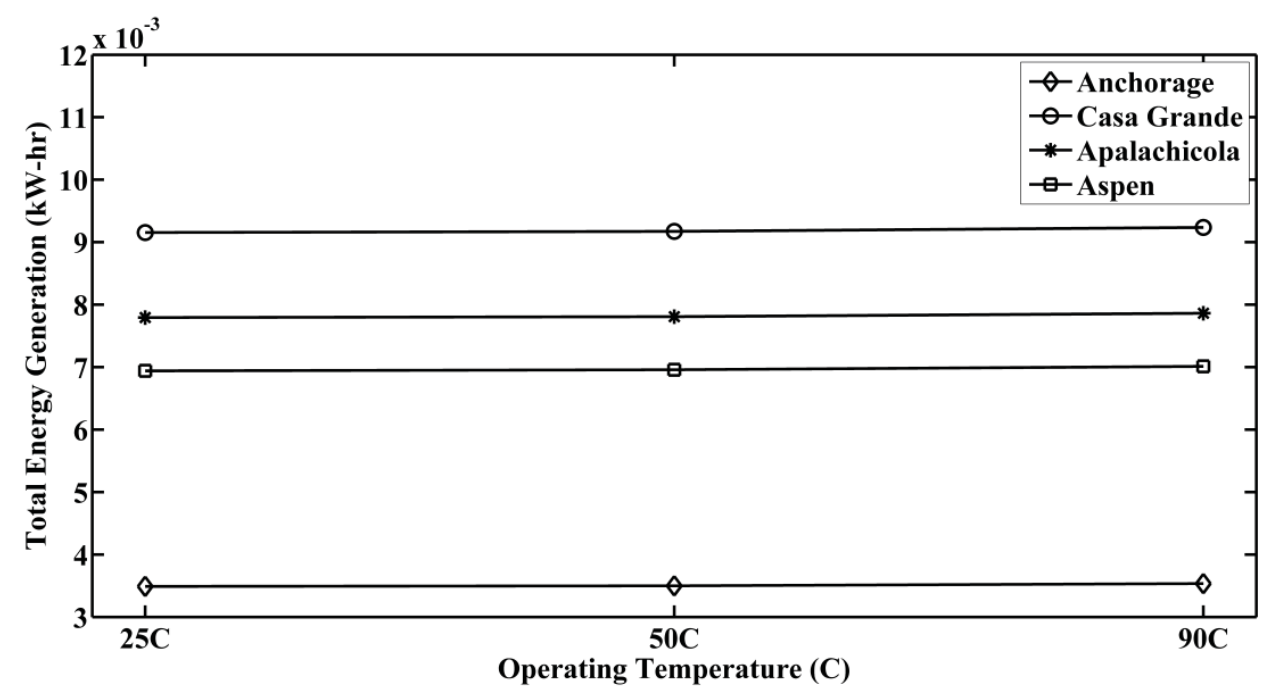

Fig. 4.9 Maximum electrical energy generation (obtained for annealing one time every day) over a year in the four cities at sustained operating temperatures 
Table 4.3 Normalized max electrical energy generation with respect to $25{ }^{\circ} \mathrm{C} \max$ energy at sustained operating temperatures (anneal cycle: once every day)

\begin{tabular}{|c|c|c|c|}
\hline Cities & $\begin{array}{c}\text { Normalized Max } \\
\text { Electrical Energy } \\
\text { at } \mathbf{2 5}{ }^{\mathbf{0}} \mathbf{C}\end{array}$ & $\begin{array}{c}\text { Normalized Max } \\
\text { Electrical Energy } \\
\text { at } \mathbf{5 0}{ }^{\mathbf{0}} \mathbf{C}\end{array}$ & $\begin{array}{c}\text { Normalized Max } \\
\text { Electrical Energy at } \\
\mathbf{9 0} \mathbf{C}\end{array}$ \\
\hline Anchorage, AK & 1 & 1.0025 & 1.0130 \\
\hline Casa Grande, AZ & 1 & 1.0019 & 1.0088 \\
\hline Apalachicola, FL & 1 & 1.0017 & 1.0087 \\
\hline Aspen, Colorado & 1 & 1.0076 & 1.0103 \\
\hline
\end{tabular}

The results of the sustained operating temperature simulation are pretty straight forward and comply with the fact that energy generation is higher at $90{ }^{\circ} \mathrm{C}$.

\subsubsection{Sensitivity and Outdoor Operating Conditions}

The outdoor temperature performance of $\mathrm{PV} / \mathrm{T}$ is distinctly complicated. For the performance analysis an environmental insulation based sensitivity study is carried out. Four cases of outdoor operating conditions are included in the study. Table 4.4 shows the list of case studies.

Table 4.4 List of case studies for outdoor operating temperature

\begin{tabular}{|l|l|}
\hline \multicolumn{1}{|c|}{ Cases } & Operating Temperature \\
\hline Case I & $90{ }^{\circ} \mathrm{C}$ (Sustained with high insulation) \\
\hline Case II & Outdoor Temperature (no insulation) \\
\hline Case III & Outdoor Temperature $+25{ }^{\circ} \mathrm{C}$ (low insulation) \\
\hline Case IV & Outdoor Temperature $+50{ }^{\circ} \mathrm{C}$ (med. insulation) \\
\hline
\end{tabular}

In Case I the PVT is considered to be highly insulated and maintains a constant operating temperature $90{ }^{\circ} \mathrm{C} .90{ }^{\circ} \mathrm{C}$ was chosen as the operating temperature as the panels 
generate more power at this temperature compared to $25{ }^{\circ} \mathrm{C}$ and $50{ }^{\circ} \mathrm{C}$ because of the annealing effects of the higher temperature on defect state density. In Case II the PVT panels are not insulated at all and operate at outdoor temperature. In Case III the PVT panels are considered to be insulated in such a way so that the operating temperature is higher than the outdoor temperature by $25{ }^{\circ} \mathrm{C}$. Case IV operating condition is similar to Case III except the fact that the panels are insulated better and operating temperature is higher than the outdoor temperature by $50{ }^{\circ} \mathrm{C}$. Figure 4.10 shows the sensitivity plot for all the outdoor operating temperature case studies.

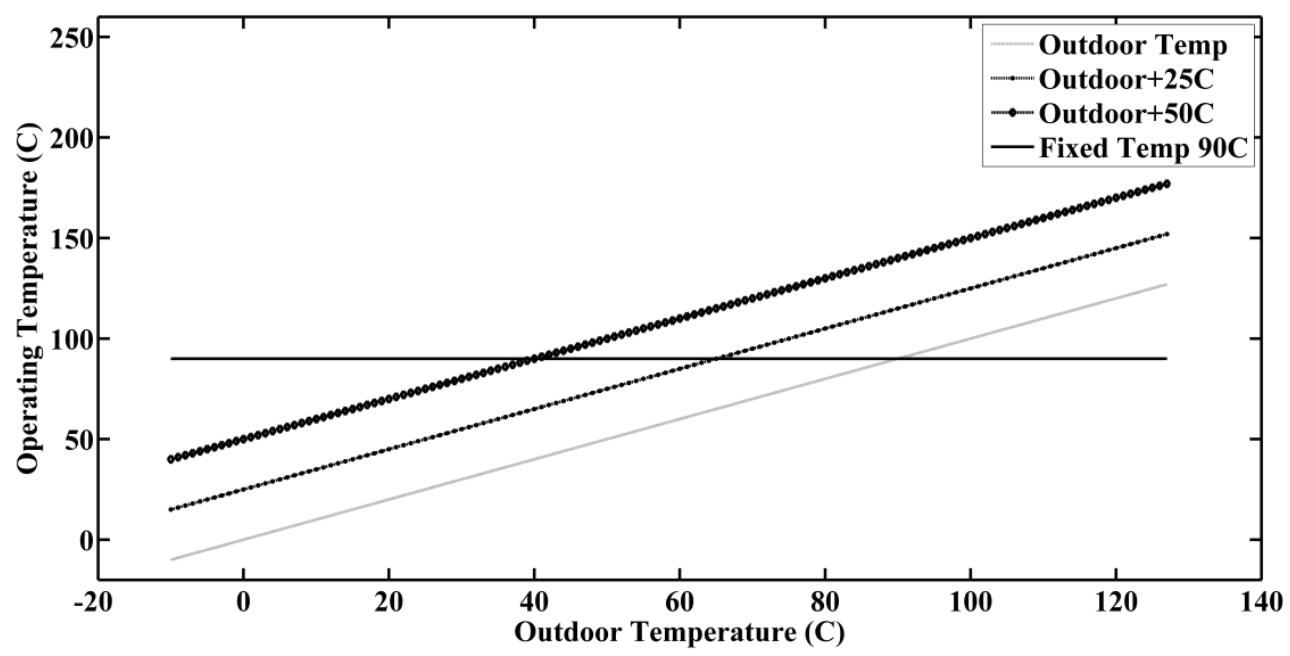

Fig. 4.10 Sensitivity study with different outdoor operating conditions

\subsubsection{Simulation at Outdoor Operating Conditions}

Outdoor simulations were performed by taking into account the outdoor operating case studies along with the anneal cycle case studies from previous work [1]. Figure $4.11,4.12,4.13$ and 4.14 shows the overall electrical energy generation for the representative cities at outdoor operating conditions. From the figures it can be seen that in each area the panels generate more power when operated at outdoor temperatures which is on average lower than $25{ }^{\circ} \mathrm{C}$ in each city. Along with the outdoor operating conditions the different annealing cycle cases starting from no anneal to 6 times anneal per day are studied in the present simulation. 
In Anchorage, AK (Figure 4.11) the effect of annealing is very minor and eventually causes a power drop while operation without annealing gives the maximum power. This behavior can be attributed to the fact that the temperature is very low in Alaska (-3.44598 ${ }^{\circ} \mathrm{C}$ on average) and at low temperatures the initial degradation rate is very small, although the DSS is worse than for higher temperatures. Also the initial drop in the power during annealing is more significant compared to the after anneal power increase. This introduces more power loss rather than compensating for the light induced degradation. Thus rapid annealing cycles, which themselves have parasitic losses do not generate additional electrical energy. In such a case it is more suitable to reduce the frequency of annealing cycles. This is discussed in detail in the latter section.

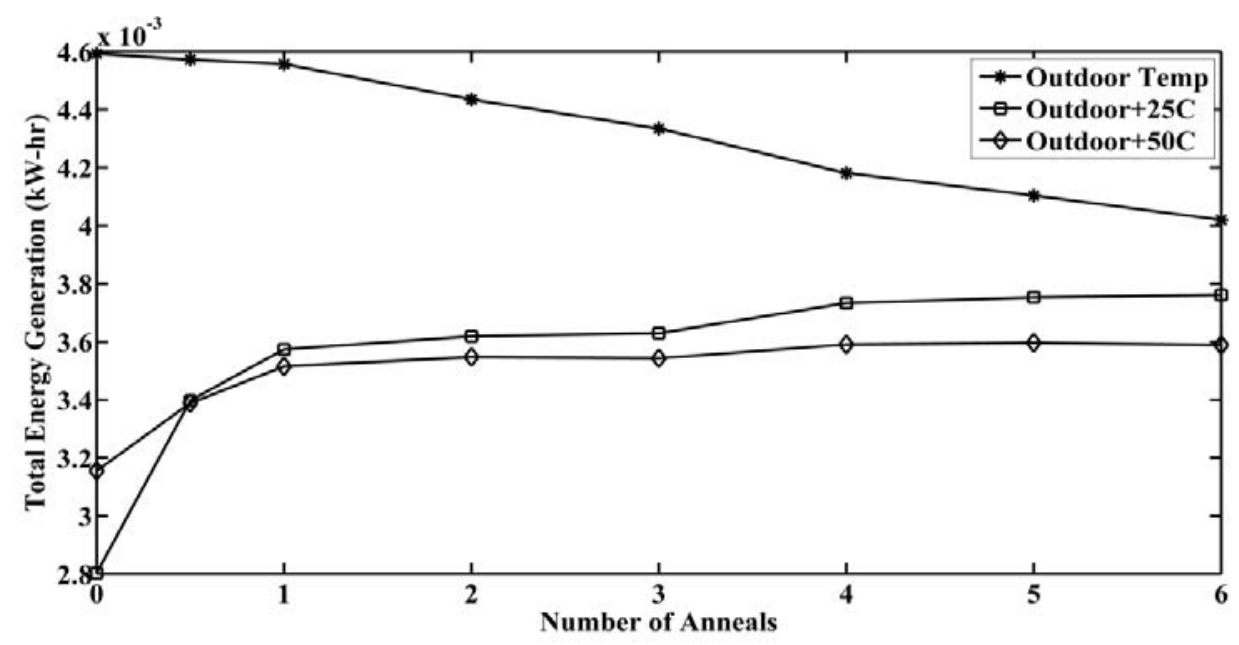

Fig. 4.11 Total electrical energy generation over a year under different annealing cycles in Anchorage, AK at outdoor operating conditions

In Casa Grande, AZ (Figure 4.12) the flux and temperature are comparatively very high. The simulation shows power generation is better at outdoor operating temperatures than the other sensitivity controlled outdoor operating conditions. Maximum power is generated with the anneal frequency five times per day. It is similar in case of Apalachicola, FL (Figure 4.13) as well except the fact that the anneal frequency is six times per day. Such requirements of high number of anneals per day in Casa Grande and Apalachicola refers to the fact that the degradation is more rapid in locations with higher 
outdoor temperature and more anneal pulses are required to compensate for this power loss due to fast states $[8,9]$. It is also true that anneal pulses are accompanied with an initial power drop but compared to the SWE degradation and after anneal rapid power boost this drop is minor. In Aspen, CO (Figure 4.14) the outdoor temperature is low for a reasonable amount of incident solar flux in this region. Simulation result shows that one time annealing everyday at outdoor operating temperature is good enough for maximum power generation.

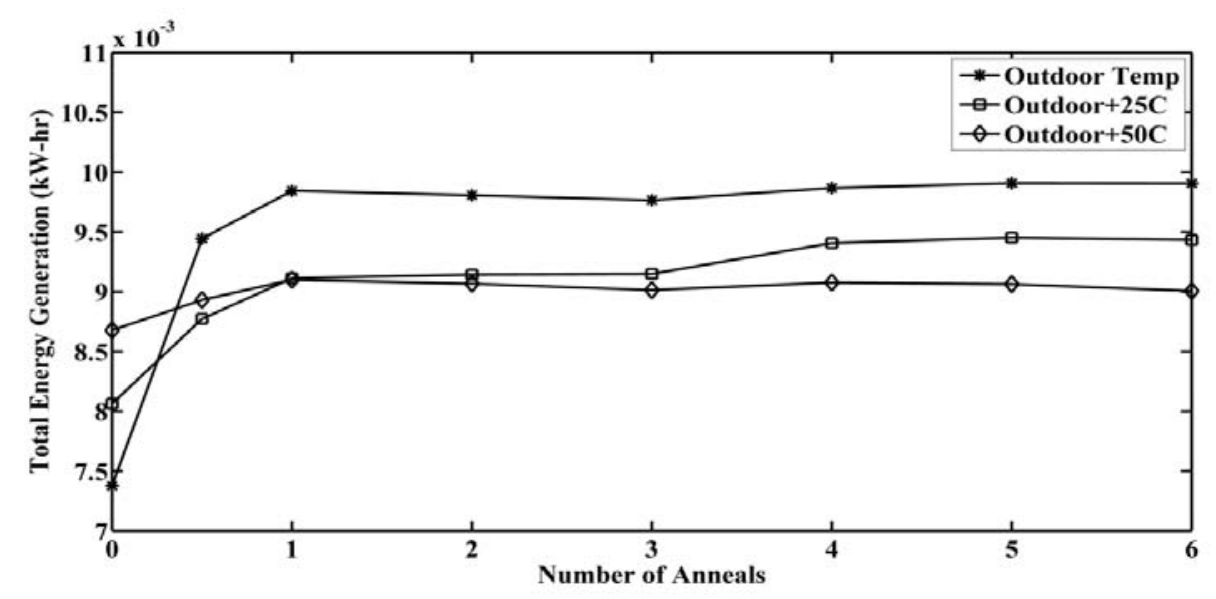

Fig. 4.12 Total electrical energy generation over a year under different annealing cycles in Casa Grande, AZ at outdoor operating conditions

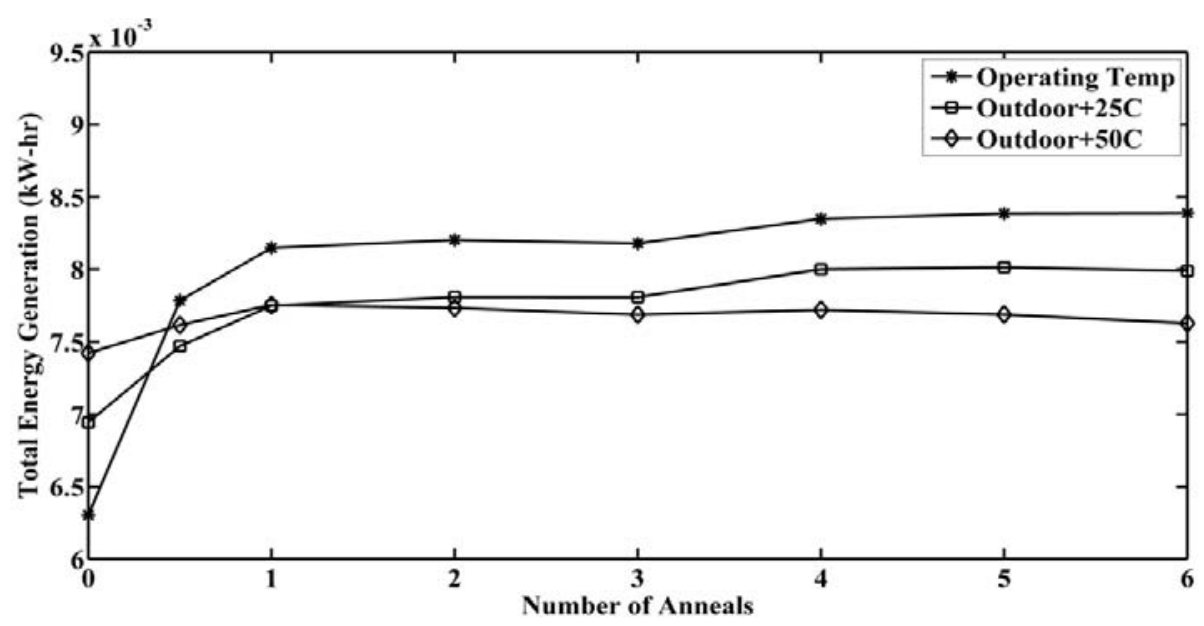

Fig. 4.13 Total electrical energy generation over a year under different annealing cycles in Apalachicola, FL at outdoor operating conditions 


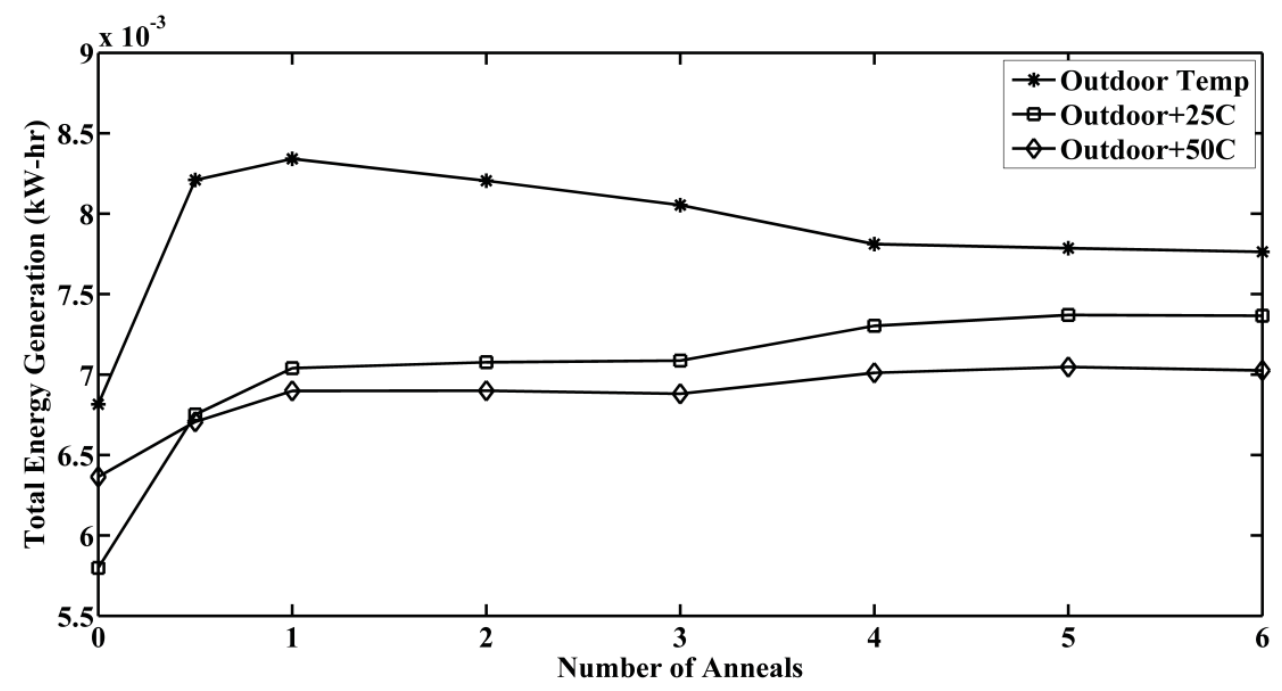

Fig. 4.14 Total electrical energy generation over a year under different annealing cycles in Aspen, $\mathrm{CO}$ at outdoor operating conditions

Figure 4.15 shows the max energy output for all the four cities and includes data for both the sustained operating temperature cases and outdoor operating temperature cases. In all the locations the outdoor operating temperature yield the maximum output. The max energy obtained at Aspen, $\mathrm{CO}$ is close to the max energy obtained at Apalachicola, FL regardless the fact that Florida gets more solar flux than Colorado. This can be attributed to the degradation rate stagnating at locations with lower outdoor temperatures. In Colorado, for example, the net electrical energy generation without annealing is higher than Florida. In Florida the flux is high, but the temperature is relatively high as well, which results in rapid degradation hence the net energy generation without annealing is lower. On the other hand additional power generation due to annealing is more in Florida compared to Colorado. This is because of the rapid degradation of generated power in Florida, which makes more room for the anneal pulses to take place and produce more annealing-associated additional electrical energy. 


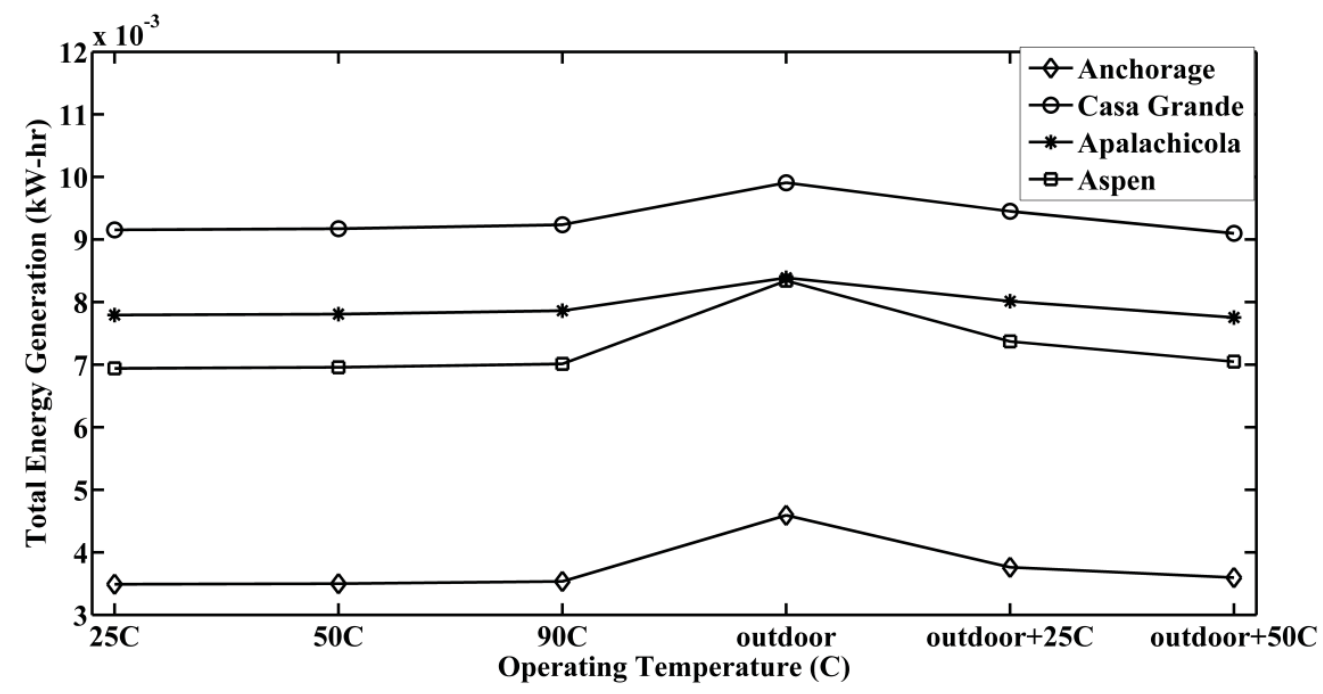

Fig. 4.15 Maximum electrical energy generation over a year for the four cities at sustained temperature (anneal cycle is one time per day) and outdoor operating conditions (anneal cycle varies from one place to another)

Table 4.5 shows the summary of the outdoor operating condition simulation. The data represents the output electrical energy at operating temperature same as the outdoor temperature. It contains the max energy obtained for the four cities when annealing is applied. The additional energy generated due to annealing is also shown.

Table 4.5 Max electrical energy generation over a year in the four cities at outdoor operating temperature

\begin{tabular}{|c|c|c|c|c|}
\hline Cities & $\begin{array}{c}\text { Max Electrical } \\
\text { Energy } \\
\text { Without } \\
\text { Annealing } \\
\mathbf{( k W - h r )}\end{array}$ & $\begin{array}{c}\text { Max } \\
\text { Electrical } \\
\text { Energy With } \\
\text { Annealing } \\
\mathbf{( k W - h r )}\end{array}$ & $\begin{array}{c}\text { Required } \\
\text { Number of } \\
\text { Anneals }\end{array}$ & $\begin{array}{c}\text { Additional } \\
\text { energy } \\
\text { Generation } \\
\mathbf{( \% )}\end{array}$ \\
\hline Anchorage, AK & 0.0046 & 0.00457 & $\begin{array}{c}\text { Once every } \\
\text { other day }\end{array}$ & $-6.52 \%$ \\
\hline Casa Grande, AZ & 0.00737 & 0.0099 & 5 times/day & $34.35 \%$ \\
\hline Apalachicola, FL & 0.0063 & 0.00838 & 6times/day & $33.17 \%$ \\
\hline
\end{tabular}




\begin{tabular}{|c|c|c|c|c|}
\hline Aspen, $\mathrm{CO}$ & 0.0068 & 0.00834 & 1 time/day & $22.47 \%$ \\
\hline
\end{tabular}

The following are the observations that summarize the whole section:

1. Outdoor operating temperature provides the maximum energy in all the representative climate cities.

2. Annealing frequency should be changed from one location to another depending on the outdoor temperature and incident solar flux

3. Effect of annealing is significant in locations with higher outdoor temperatures. The additional energy generation due to annealing is higher in Casa Grande, AZ (34.35\%) and Apalachicola, FL (33.17\%) where the outdoor temperature is higher on average. Also the annealing frequency is high for generation of this amount of additional power. For Casa Grande the anneal frequency is five times per day and for Apalachicola it is six times per day. In other words, annealing associated additional energy generation is higher in places with higher temperature.

4. Max energy generation (without annealing at outdoor operating temperatures) is higher in regions with lower outdoor temperatures. As for example, Aspen, CO gets lower flux compared to Apalachicola, FL yet generates more power than Apalachicola without annealing (as per Table 4.5). This can be attributed to the lower outdoor temperature in Aspen which stagnates the power degradation rate.

5. In locations with extremely low temperatures, the effect of annealing is minor and a-Si:H PVT panels do not necessarily generate additional electrical energy under rapid annealing cycles. On the other hand, the maximum electrical energy without annealing is high. As for example, the additional energy generation due to annealing (once every other day) in Anchorage, AK is $-6.52 \%$, which represents an electrical energy loss. 


\subsubsection{Appropriate Dispatch Strategy}

The preceding sections ascertained that annealing contribute to additional electrical energy generation in PVT. But annealing is also accompanied with PVT panel thermal energy consumption. Hence it is necessary to optimize the annealing cycle and obtain the most effective dispatch strategy for the total energy. This is left for future work, which should use exergy to determine the optimal routine. A sensitization was perfomed on following bases:

1. Depending on the climate features of any particular region dispatch strategy should be adapted

2. The frequency of annealing should be as low as possible- reduces the annealing associated thermal energy consumption

3. The energy generation should be as high as possible and must be close to max energy generation

The dispatch strategy reasoning for each city is discussed in detail in following segments.

a) Anchorage (Alaska): The outdoor operating temperature simulation result shows that max power in Anchorage was obtained without annealing and rapid annealing reduces power generation. The power degradation rate is very low due to extremely low outdoor temperature. Hence it is required to reduce the frequency of annealing cycles to obtain power greater than the no anneal situation. Using the rules above, annealing only once in a year (approximately after 8640 hours) was chosen to be an ideal strategy for this city. It resulted in generation of $.000345 \%$ additional energy which is very negligible. Further reduction of annealing frequency i.e. annealing once in every two years will possibly provide additional energy. 
b) Casa Grande (Arizona): In Casa Grande the max energy was obtained for the strategy that consists of five times annealing everyday at outdoor operating temperature. In Table 4.5 an additional energy of $34.35 \%$ is reported for this strategy. It has also been observed that one time annealing per day generates $33.45 \%$ additional energy which is fairly close to the energy generation with five times anneal per day. This will also reduce the annealing associated heating energy consumption. Thus annealing once every day should be a good compromise dispatch strategy for Casa Grande.

c) Apalachicola (Florida): In Apalachicola the max energy was obtained for a dispatch strategy consisting six times annealing per day- resulted in $33.17 \%$ additional energy generation. If the anneal cycle is reduced to one time every day $29.33 \%$ additional electrical energy generation is still generated, while cutting the annealing associated heating energy consumption down by a factor of six. This compares to the exergy for PV being higher than solar thermal for PV systems by a factor of six.

d) Aspen (Colorado): According to Table 4.5, the maximum energy for Aspen was obtained for the strategy- one time anneal every day. This strategy is also likely to provide a favorable dispatch strategy for Aspen with $22.47 \%$ additional electrical energy generation.

Table 4.6 shows comparison of the dispatch strategies that give the maximum electrical energy with the strategies that gives favorable PVT performance. The calculation only involves electrical energy generation and hence it is not the optimized one. The appropriate dispatch strategy in this case can be defined as the strategy that generates electrical energy close to max possible electrical energy with lower frequency of anneal cycles. Similarly max energy dispatch strategy refers to the strategy that generates maximum electrical energy. 
Table 4.6 Comparison between max electrical energy dispatch strategies and appropriate strategies

\begin{tabular}{|c|c|c|c|c|c|c|c|c|c|}
\hline \multirow{2}{*}{ Cities } & \multirow{2}{*}{$\begin{array}{c}\text { Max } \\
\text { Energy } \\
\text { Without } \\
\text { Anneali } \\
\text { ng (kW- } \\
\text { hr) }\end{array}$} & \multicolumn{3}{|c|}{$\begin{array}{c}\text { Max Electrical Energy Dispatch } \\
\text { Strategy }\end{array}$} & \multicolumn{5}{|c|}{ Appropriate Dispatch Strategy } \\
\hline & & $\begin{array}{c}\text { Generated } \\
\text { Electrical } \\
\text { Energy } \\
(\mathrm{kW}-\mathrm{hr})\end{array}$ & $\begin{array}{c}\text { Required } \\
\text { Number of } \\
\text { Anneals }\end{array}$ & $\begin{array}{c}\text { Additional } \\
\text { energy } \\
\text { Generation } \\
(\%)\end{array}$ & $\begin{array}{c}\text { Generated } \\
\text { Electrical } \\
\text { Energy (kW- } \\
\text { hr) }\end{array}$ & $\begin{array}{c}\text { Required } \\
\text { Number of } \\
\text { Anneals }\end{array}$ & $\begin{array}{c}\text { Additiona } \\
\text { I energy } \\
\text { Generatio } \\
\text { n (\%) }\end{array}$ & Advantage & $\begin{array}{l}\text { Draw } \\
\text { backs }\end{array}$ \\
\hline $\begin{array}{c}\text { Anchorag } \\
\text { e, AK }\end{array}$ & $\begin{array}{c}0.004592 \\
592\end{array}$ & $\begin{array}{c}0.00459259 \\
2\end{array}$ & No Anneal & $0 \%$ & $\begin{array}{c}0.004592608 \\
7\end{array}$ & $\begin{array}{c}\text { Once every } \\
\text { year }\end{array}$ & $.000345 \%$ & $\begin{array}{c}\text { Energy } \\
\text { generation } \\
\text { increased }\end{array}$ & N/A \\
\hline $\begin{array}{c}\text { Casa } \\
\text { Grande, } \\
\text { AZ }\end{array}$ & 0.00737 & 0.0099 & 5 times/day & $34.35 \%$ & 0.009843 & 1 time/day & $33.45 \%$ & $\begin{array}{c}\text { Reduces } \\
\text { annealing } \\
\text { associated } \\
\text { energy } \\
\text { consumption }\end{array}$ & $\begin{array}{c}\text { Energy } \\
\text { generatio } \\
\mathrm{n} \\
\text { decreased }\end{array}$ \\
\hline $\begin{array}{c}\text { Apalachic } \\
\text { ola, FL }\end{array}$ & 0.0063 & 0.00838 & 6times/day & $33.17 \%$ & 0.008148 & 1 time/day & $29.33 \%$ & $\begin{array}{c}\text { Reduces } \\
\text { annealing } \\
\text { associated } \\
\text { energy } \\
\text { consumption }\end{array}$ & $\begin{array}{c}\text { Energy } \\
\text { generatio } \\
\mathrm{n} \\
\text { decreased }\end{array}$ \\
\hline $\begin{array}{l}\text { Aspen, } \\
\text { CO }\end{array}$ & 0.0068 & 0.00834 & 1 time/day & $22.47 \%$ & 0.00834 & 1 time/day & $22.47 \%$ & N/A & N/A \\
\hline
\end{tabular}




\section{CHAPTER REFERENCES}

[1] Rozario J, Vora AH, Debnath SK, Pathak MJM, Pearce JM. The effects of dispatch strategy on electrical performance of amorphous silicon based solar photovoltaic thermal systems. Renewable Energy. Renewable Energy. 2014;16:459-465. doi: 10.1016/j.renene.2014.02.029

[2] Pathak MJM, Pearce JM, Harrison SJ. Effects on amorphous silicon photovoltaic performance from high-temperature annealing pulses in photovoltaic thermal hybrid devices. Solar Energy Mater Solar Cells 2012;100:199-203. http://dx.doi.org/10.1016/j.solmat.2012.01.015.

[3] National Solar Radiation Database, National Renewable Energy Laboratory, Golden, Colorado. <http://rredc.nrel.gov/solar/old_data/nsrdb/>; 2014.

[4] National Climactic Data Center, National Oceanic and Atmospheric Administration, Silver Spring, Maryland.

$<$ http://www.ncdc.noaa.gov/oa/climate/severeweather/hurricanes.html>; 2014.

[5] NREL Solar Propector, National Renewable Energy Laboratory, Golden, Colorado. $<$ http://maps.nrel.gov/prospector>; 2014.

[6] Natural Resources Canada. <http://www.nrcan.gc.ca/home>; 2014.

[7] Wilcox S. National solar radiation database 1991-2010 update: user's manual. NREL Technical Report. 2012. <http://www.nrel.gov/docs/fy12osti/54824.pdf>.

[8] Yang L, Chen L. "Fast" and "slow" metastable defects in hydrogenated amorphous silicon. Appl. Phys. Lett. 1993;63:400-402. http://dx.doi.org/10.1063/1.110031

[9] Pearce JM, Koval RJ, Niu X, May SJ, Collins RW, Wronski C R. The 'fast' and 'slow' light induced defects in diluted and undiluted hydrogenated amorphous silicon 
solar cells and materials. In Proc. 17th Eur. Photovoltaic Solar Energy Conf.; 2002. pp. $2842-2845$ 



\section{CHAPTER 5}

\section{Discussion, Future Work and Conclusions}

Amorphous silicon based solar cells have a lower thermal coefficient than c-Si, but their performance is undermined by the fact that long time light exposure causes formation of defect states that reduces power generation. Fortunately, a-Si:H also has the ability to reduce the quantity of defect states with exposure to high temperature annealing pulses. This property makes them more suitable for PV/T applications where the thermal collector temperature can be easily raised to the annealing temperature. Yet suitable dispatch strategies are prerequisite to obtain the optimal benefits of the PV/T assembly. Earlier chapters sum up the investigation methodologies and results of variant dispatch schemes. This chapter contains the discussions including the consistency of the simulation, limitations of the present method, improvements and the future works.

\subsection{Discussions}

\subsubsection{Consistency of Simulation}

The consistency of the simulation determines how accurate results are obtained. In the current method of outdoor environment operation of PVT it has been considered that the panels operate at outdoor temperature. In reality the temperature of the PVT panels get higher than the outdoor temperature which eventually affects the PVT degradation behavior and also the PVT panel output. It is really hard to obtain accurate panel temperature from theory as heat is transferred mostly through conduction mechanism and there exist temperature gradient between each component in the module. Both experimental and theoretical studies of thermal conductance and heat transfer in a-Si:H is required to perform for better understanding of the phenomenon. 


\subsubsection{Limitations of the Simulation Method}

One of the major drawbacks of the model is the accuracy of values of the degradation associated constants $k_{d s s}$ and $u_{d s s}$. These values were calculated linearly from the plots shown in Figure 4.1 and 4.2. Also the values of the parameters outside the $25{ }^{\circ} \mathrm{C}-90{ }^{\circ} \mathrm{C}$ range were calculated by extending the line on both sides. The technique is not very efficient. As the number of basic data points were limited to three it was not possible to obtain an accurate fitting. Given more data points of $k_{d s s}$ and $u_{d s s}$ values in between the range $25{ }^{\circ} \mathrm{C}$ to $90{ }^{\circ} \mathrm{C}$ it will be possible to come up with a more accurate fitting curve for $k_{d s s}$ and $u_{d s s}$. The range of experimental data must include the 1 sun PV/T degradation plots below $25{ }^{\circ} \mathrm{C}$ (e.g. $-10{ }^{\circ} \mathrm{C}$ to $25{ }^{\circ} \mathrm{C}$ ) as that range of temperature is more favorable for $\mathrm{PV} / \mathrm{T}$ operation.

Another limitation of the degradation associated parameters is their value limits. The value of $u_{d s s}$ falls with decrease in temperature and after certain temperature (approximately $2{ }^{\circ} \mathrm{C}$ ) the value of $u_{d s s}$ becomes negative. Theoretically it is not possible for $u_{d s s}$ to obtain negative value because that refers to rise in power rather than degradation. Thus when $u_{d s s}$ value is below 0 the value is set to 0 . Similarly the max limit for $k_{d s s}$ value is 0.4642 and the parameter value cannot exceed the limit. Exceeding the limit deteriorates degradation behavior.

From the study of PV/T performance and dispatch strategy in Alaska it was found that annealing has very minor impact on additional power generation in this region. Annealing only one time in a year resulted in a negligible amount of additional energy generation $(.000345 \%)$. It is possible that annealing only once in two or three years may yield higher additional energy generation. Due to limited access to data it was not possible to effectively optimize the situation.

The calculation of appropriate dispatch strategy does not include the thermal energy consumption associated with annealing and hence is not optimized. This portion of energy is a part of the energy loss and may change the energy output at a high margin and needs to be investigated in the future. Also due to the limitation of access to required data 
and insufficiency of resources it was not possible to gather the data from all around the world. With more availability of global data better understanding of PVT behavior is possible.

\subsection{Future Work}

This study broadened the future scope of research in the field of a-Si:H PVT dispatch strategy and annealing. One of the more highlighted topics will be fitting the degradation associated parameter curves more accurately using experimental values. In addition, more detailed studies of snow and its impact on solar energy devices [1] such as PVT performance can provide insight into the dispatch strategies and annealing cycles in snowbound areas. Moreover, using PV/T trade-off between the thermal power and electric power is possible upon users demand. In other words, tunability between the thermal and electric power is possible. This will give users more flexibility on usage of PVT and they can set the PVT operating condition upon their instant demand of thermal power or electric power. Studies of the temperature/annealing controller aided automatic generation of anneal sequence as a function of outdoor temperature and flux will make the whole system more useful and practical for global application. Finally mathematical computation of thermal energy consumption due to spike annealing could be a good topic for experimental research.

\subsection{Conclusion}

The results of the initial study (Chapter 3), investigated the impact of annealing cycles and geographic locations with real solar flux data showed that at standard and sustained PV operating temperatures one anneal pulse per day provided the largest electrical output through the year. The results showed that significant amount of additional energy generation is possible over the year with an appropriate dispatch strategy and operating temperature providing 23\%,10\%, and 1.2\% additional energy generation over a year for the operating temperatures $25{ }^{\circ} \mathrm{C}, 50{ }^{\circ} \mathrm{C}$, and $90{ }^{\circ} \mathrm{C}$ respectively. The outcome inclined that further study of annealing cycles and analysis of the degradation at other operating temperatures coupled with the optimization of the 
thermal component of the PV/T can provide the optimal dispatch strategy for the devices for any application.

The latter part of the study (Chapter 4) is an expansion of the earlier work aimed to diagnose the real world outdoor environment performance of PVT under application of annealing cycles. The study includes solar data from all over U.S. and Canada. The main feature of the model is that it expands the limits of operation from sustained operating temperatures to outdoor operating temperature. The result of simulation reports the impact of annealing and maximum possible energy outputs at different outdoor operating conditions. It was found that compared to sustained temperature operation the energy generation is more when PV/Ts are operated at outdoor temperatures. Finally, a logical approach was taken to optimize the dispatch strategies which hold limitations with the accurate reckoning of the associated exergy and thermal energy. The present work concludes with the notion that with access to required data and considering the bases of sensitization as the rule of thumb it is possible to implement suitable dispatch strategies and execute virtual performance analysis of PV/T for any places around the world. 


\section{CHAPTER REFERENCES}

[1] Andrews RW, Pollard A, Pearce JM, "The Effects of Snowfall on Solar

Photovoltaic Performance. Solar Energy. 2013;92: 84-97. doi: 10.1016/j.solener.2013.02.014. 



\section{Appendix I}

\section{Program Code: Ideal Cases}

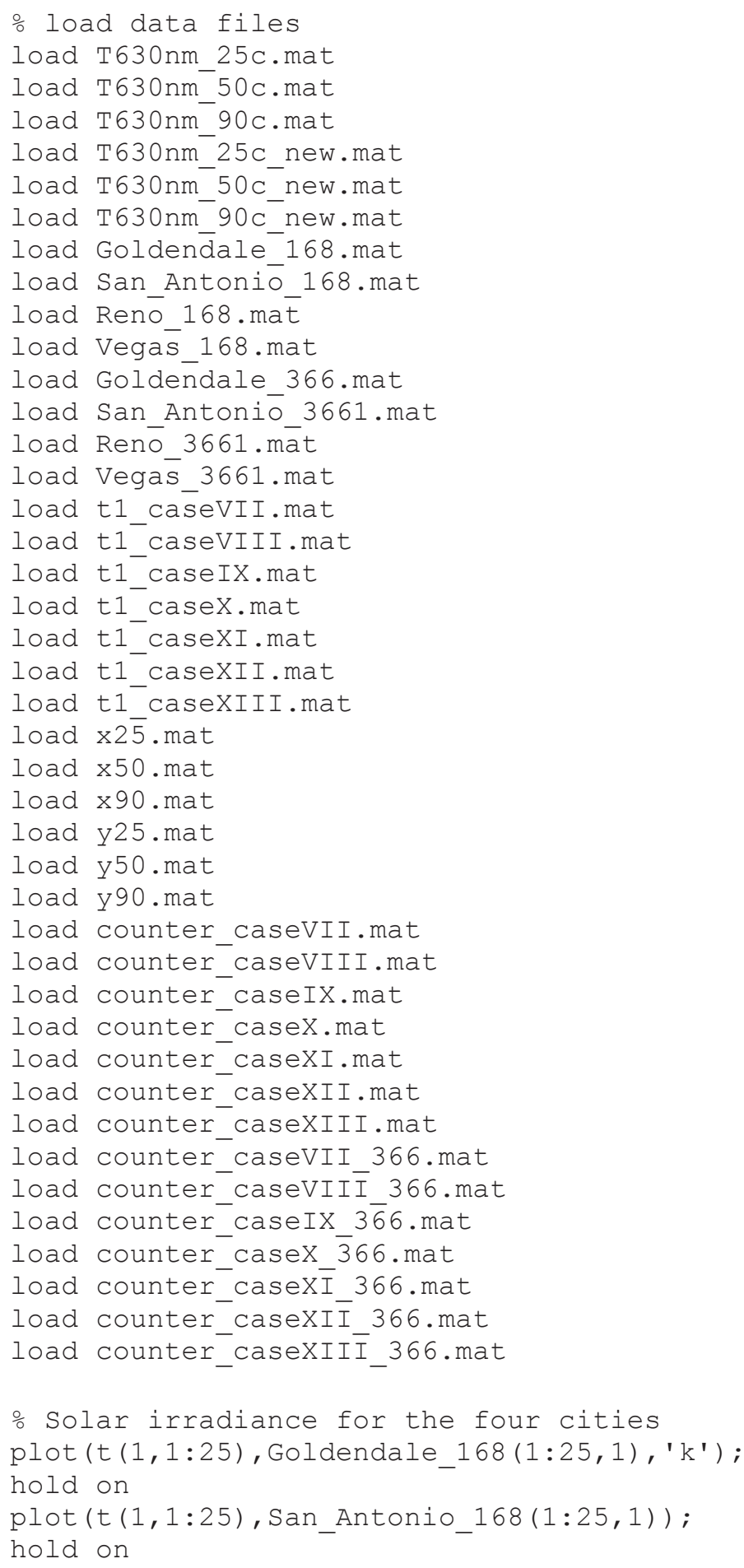




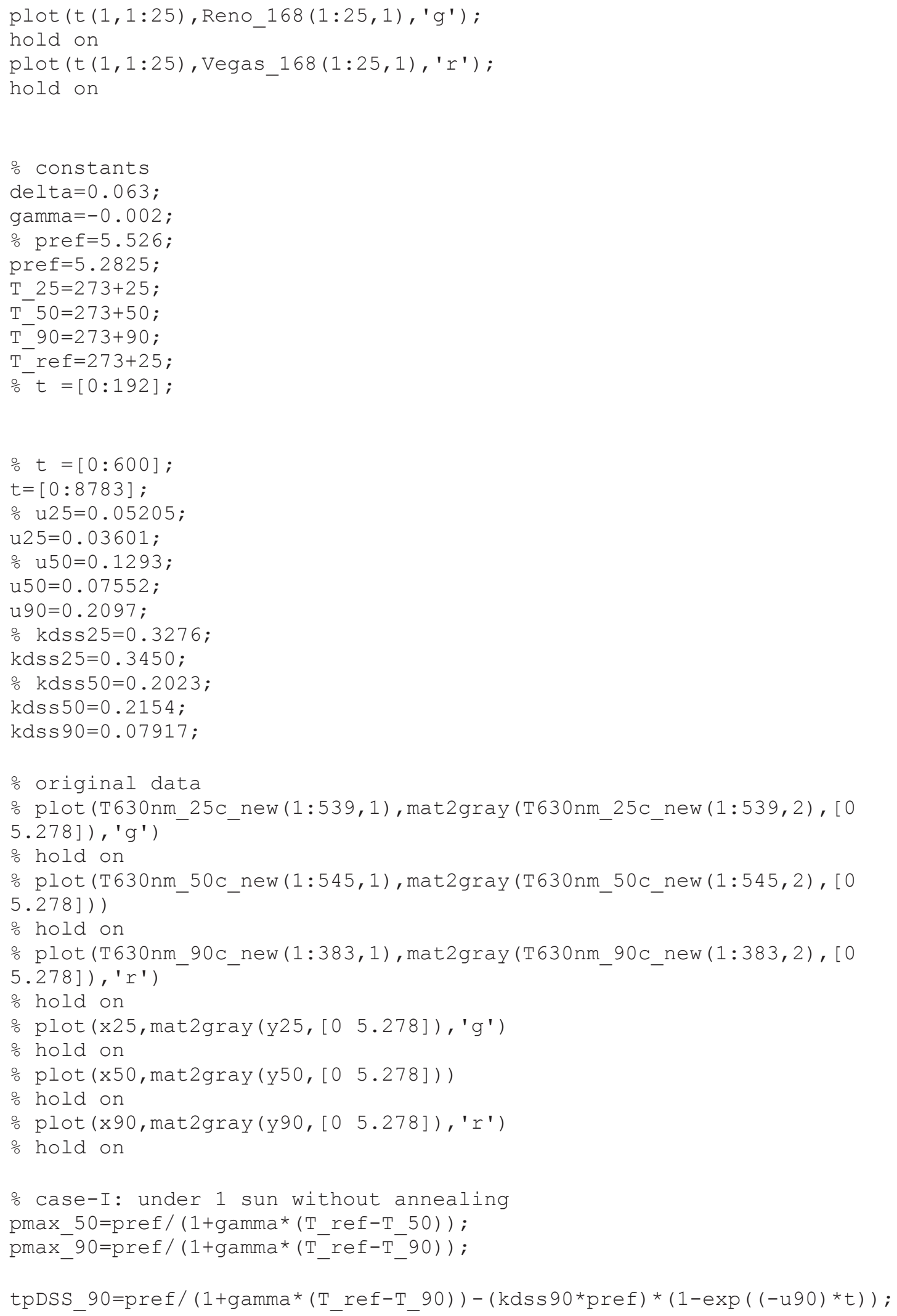




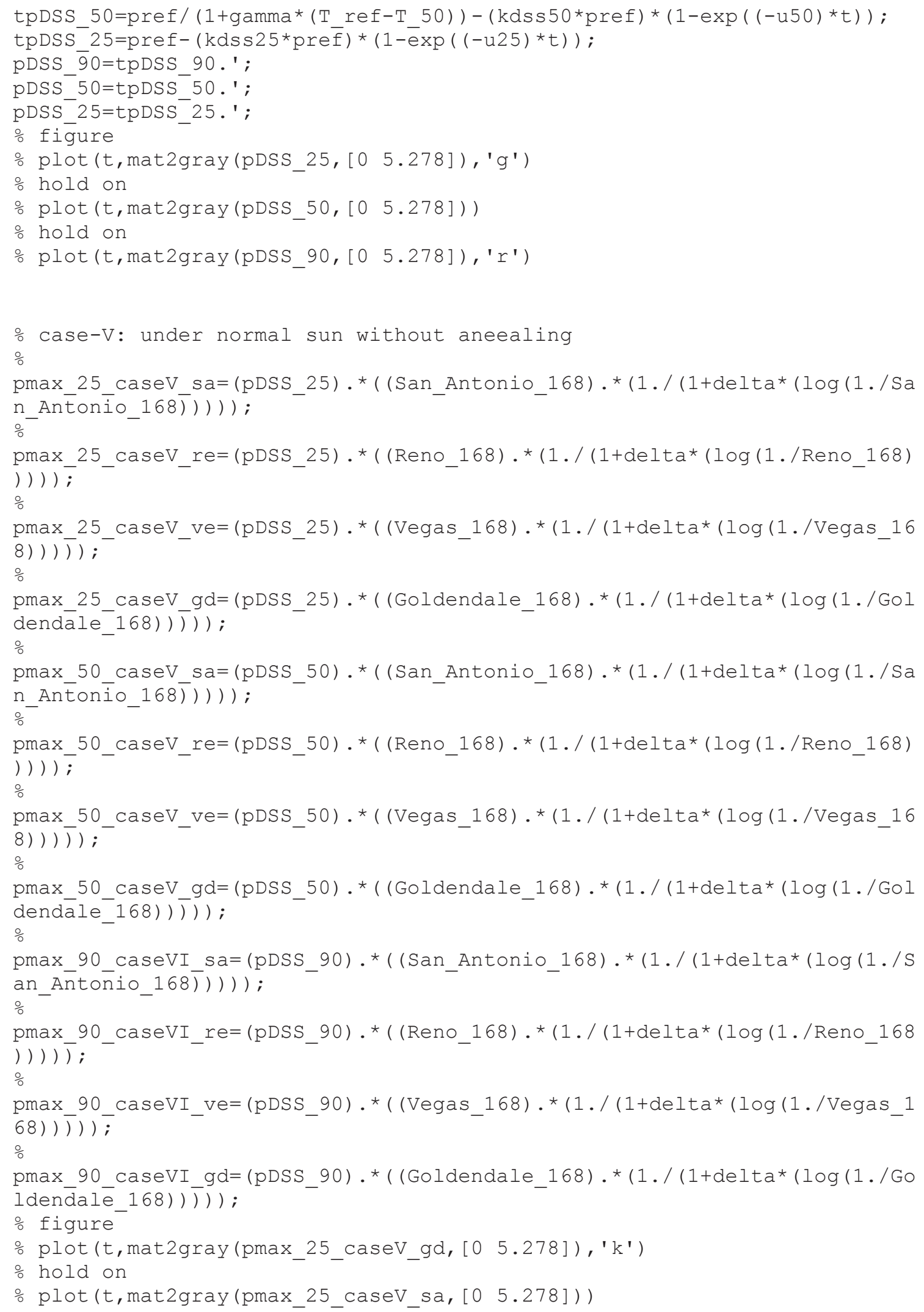




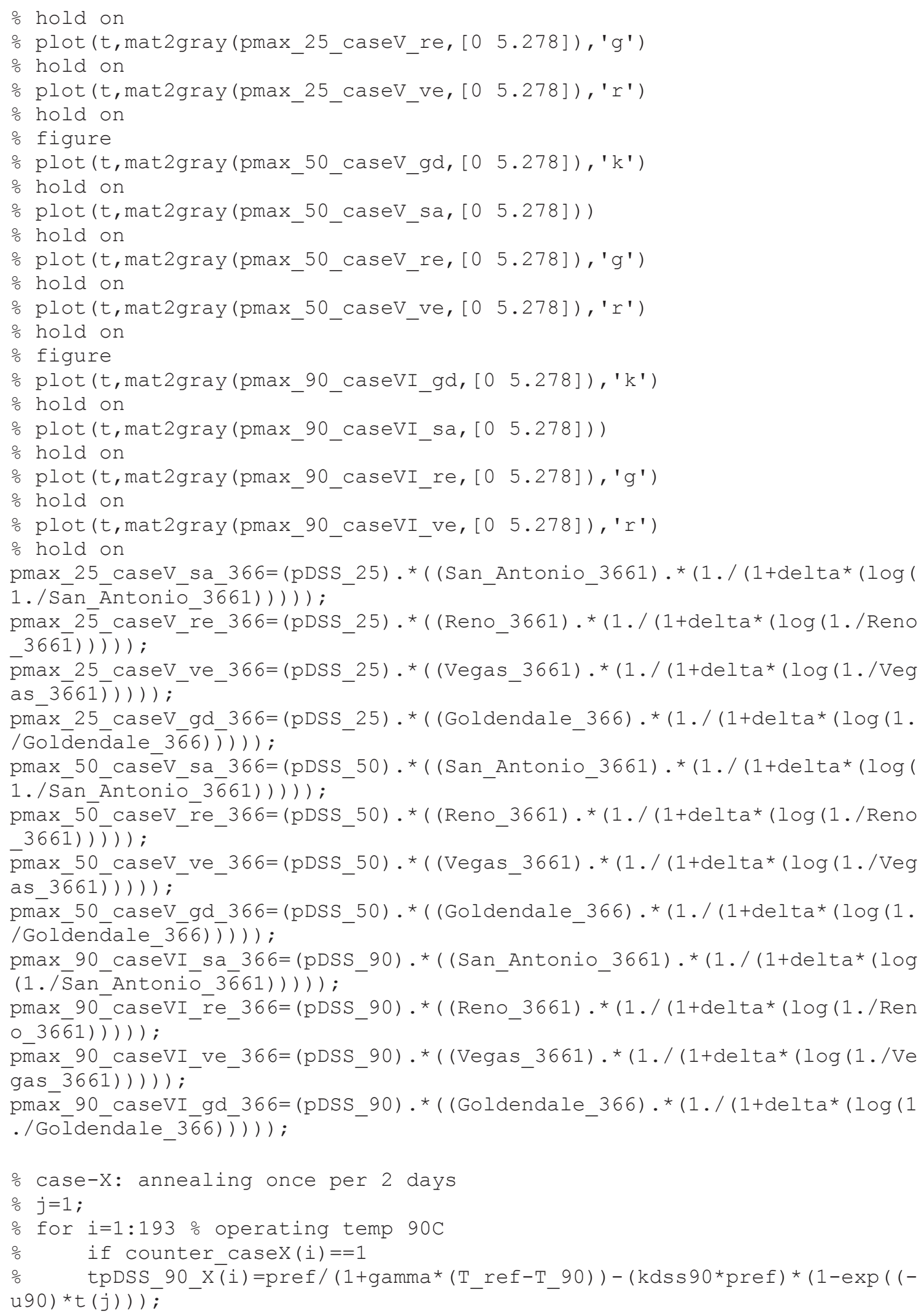




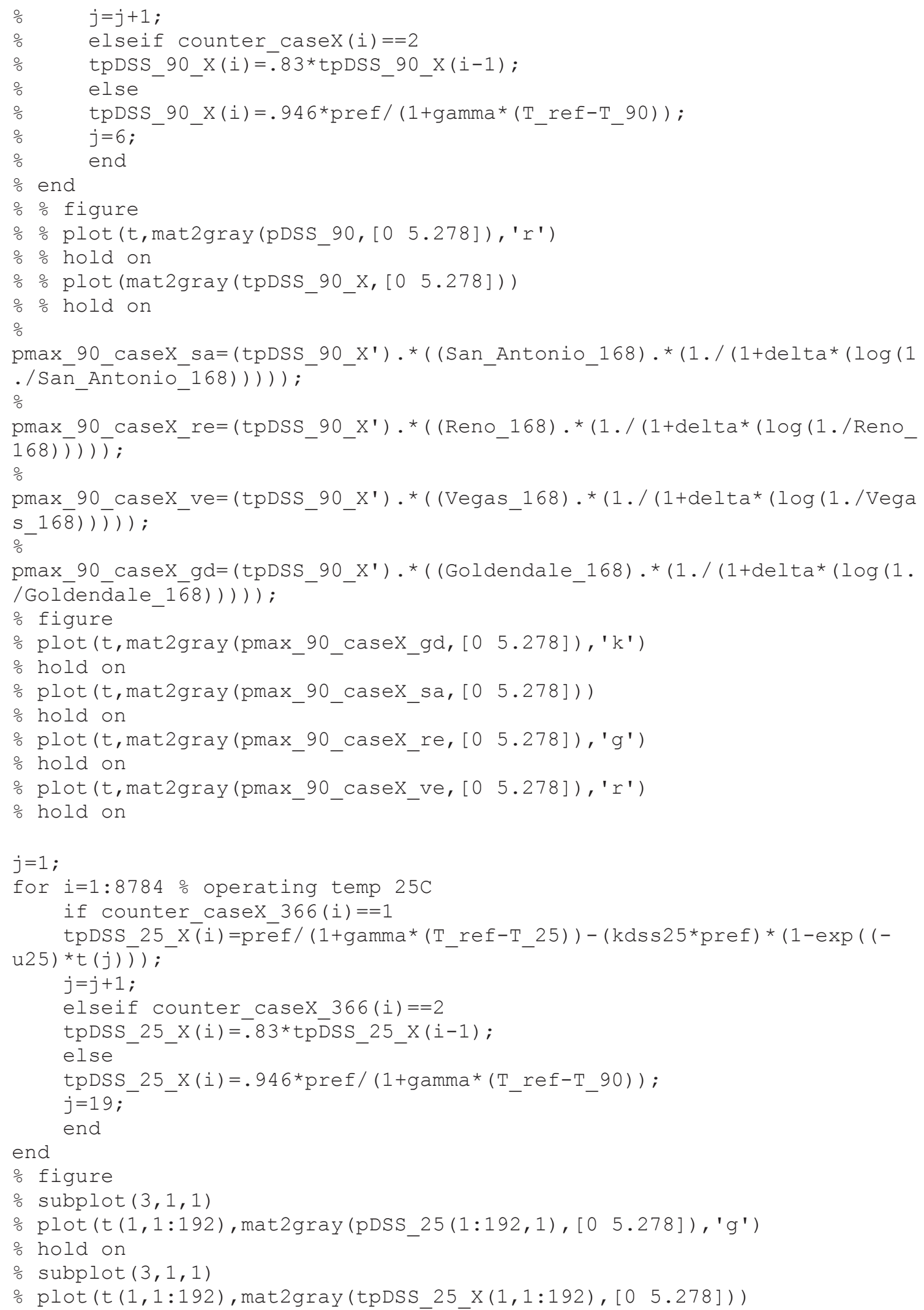




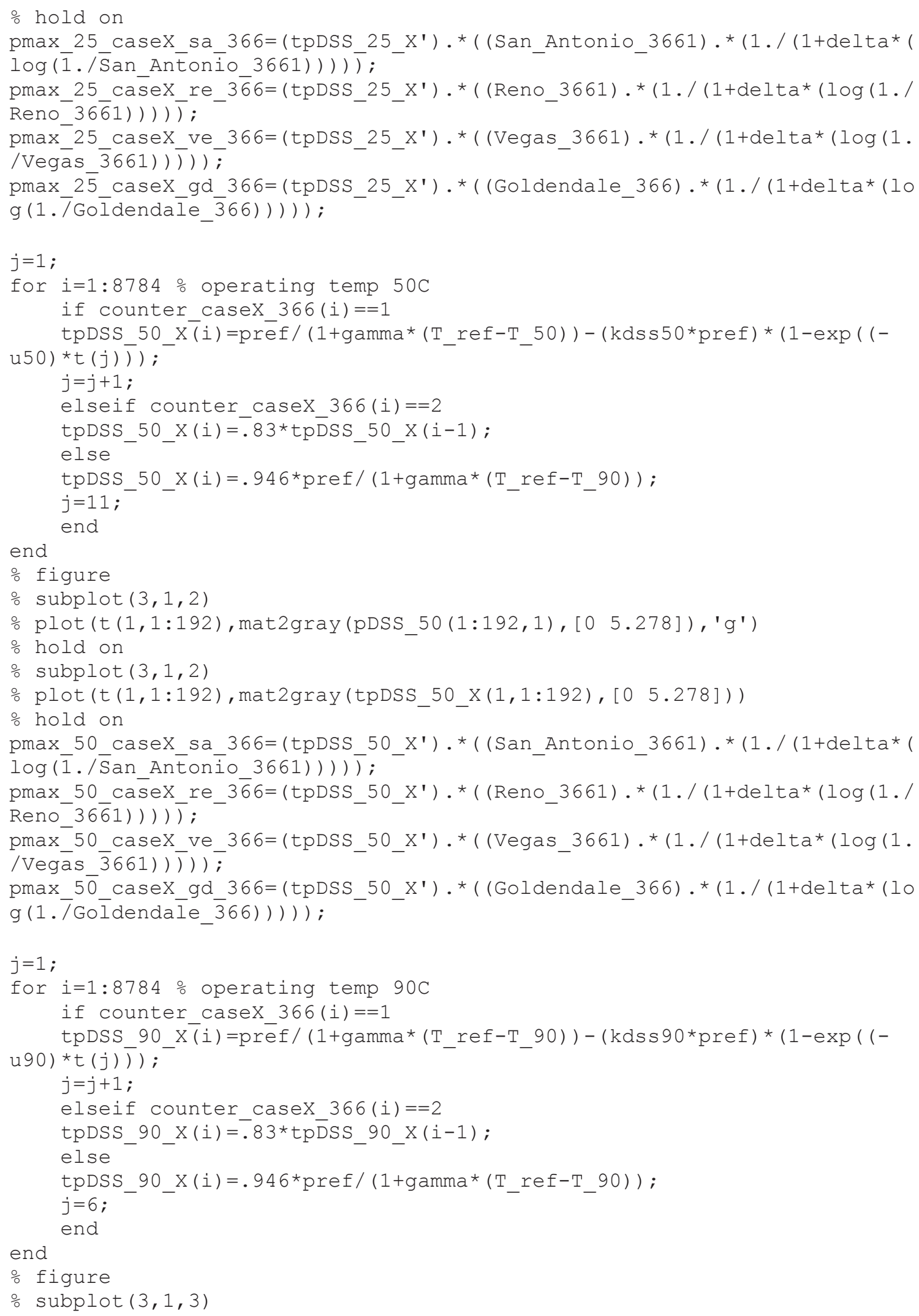




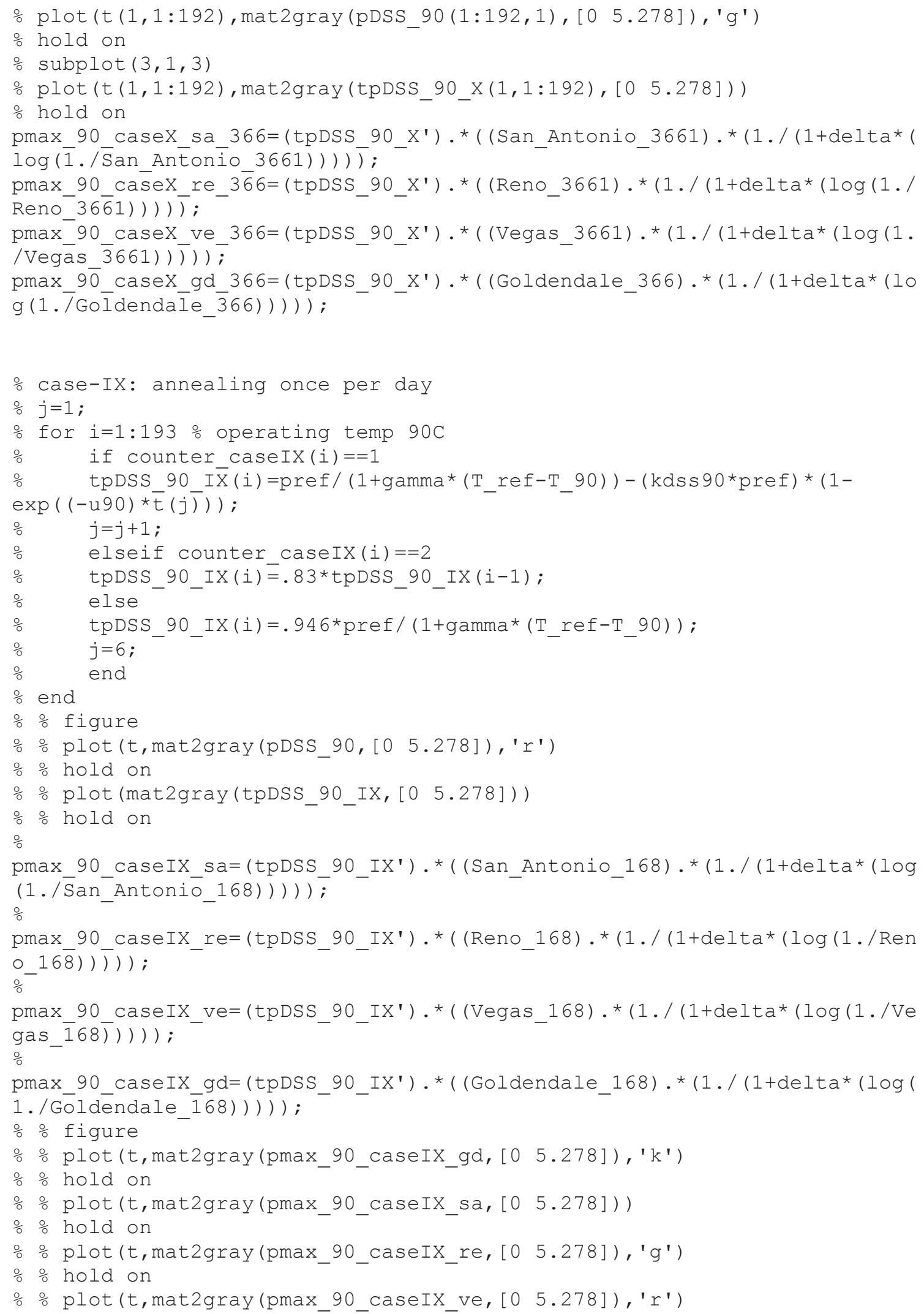


응 hold on

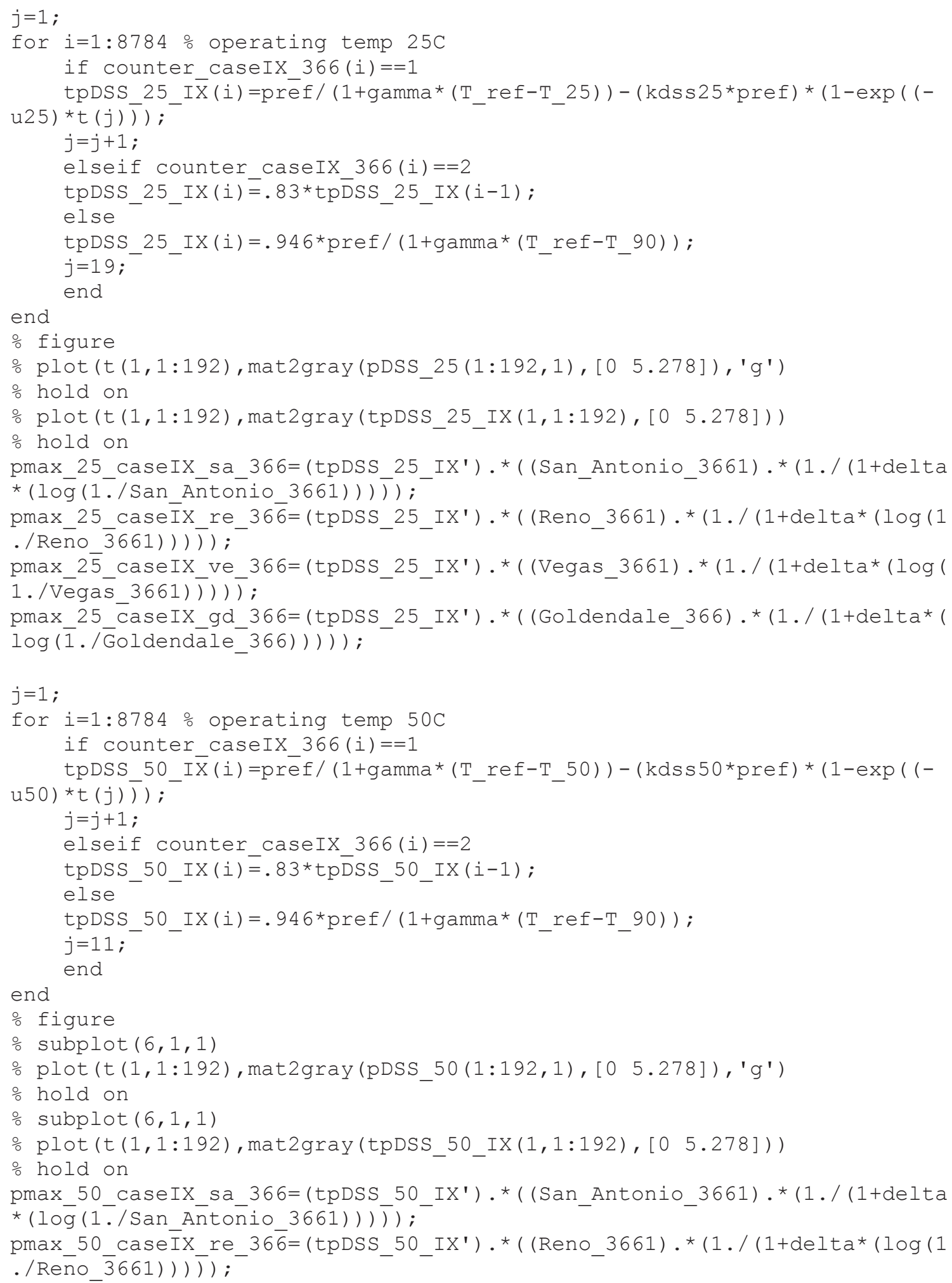




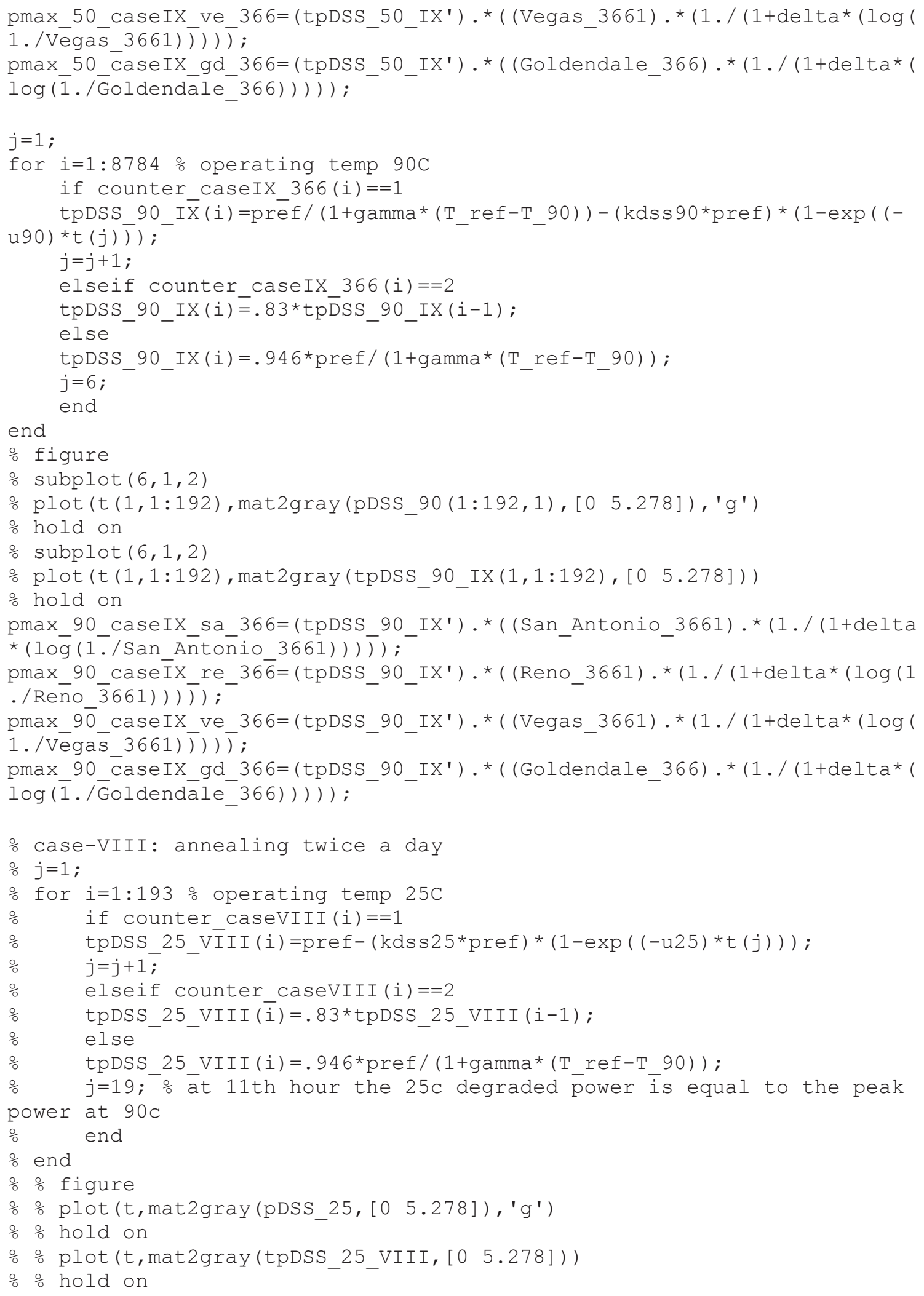




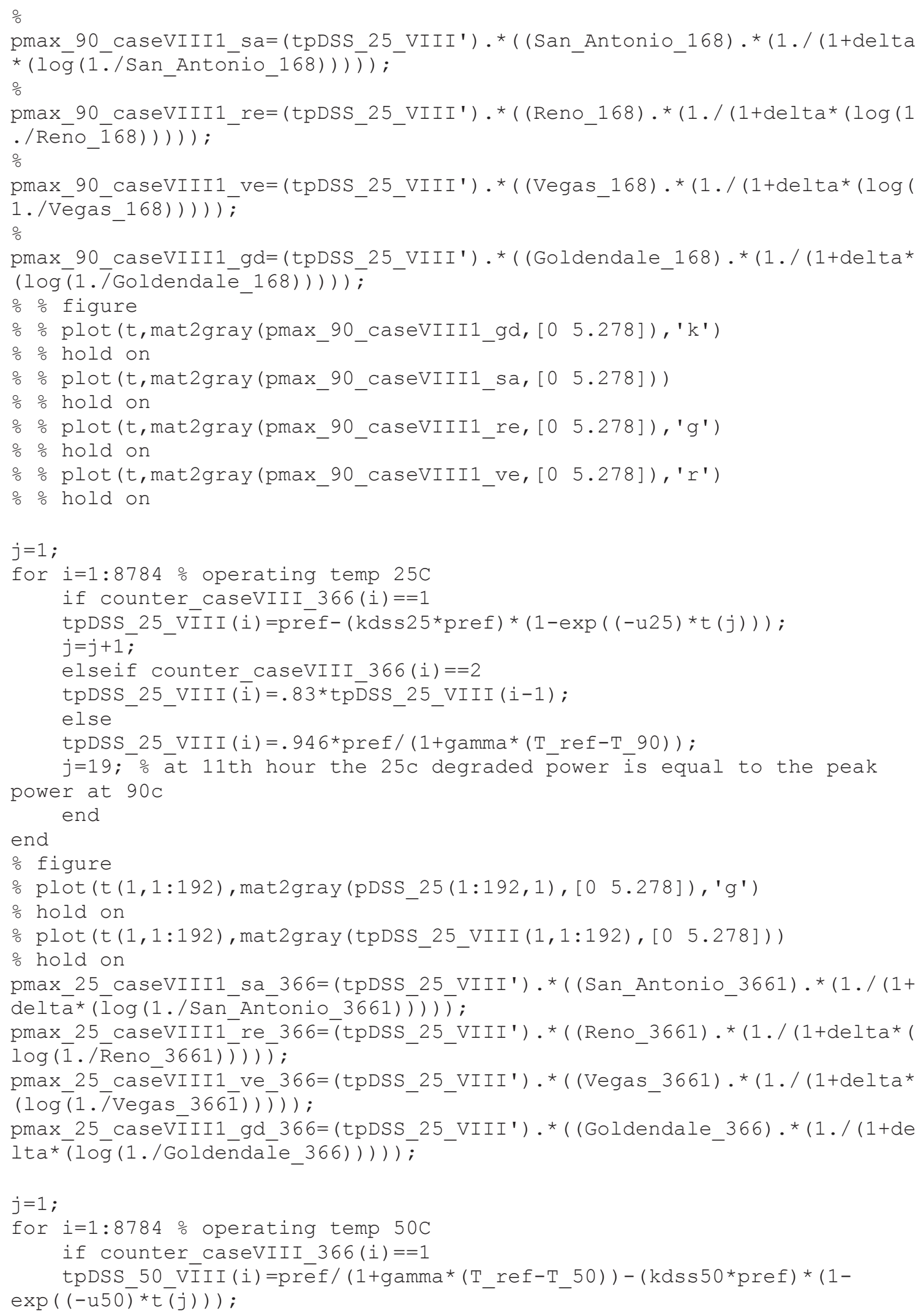




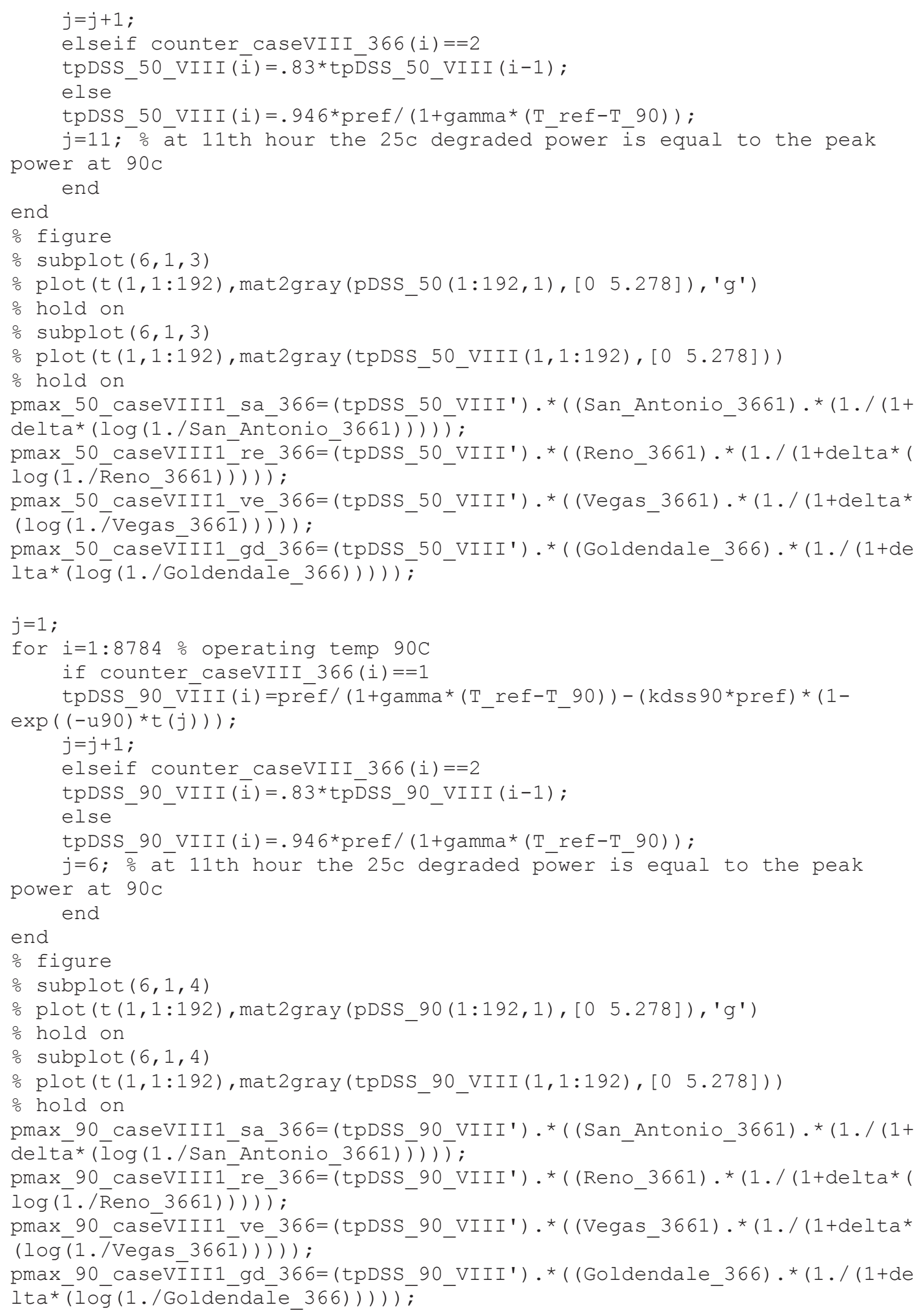




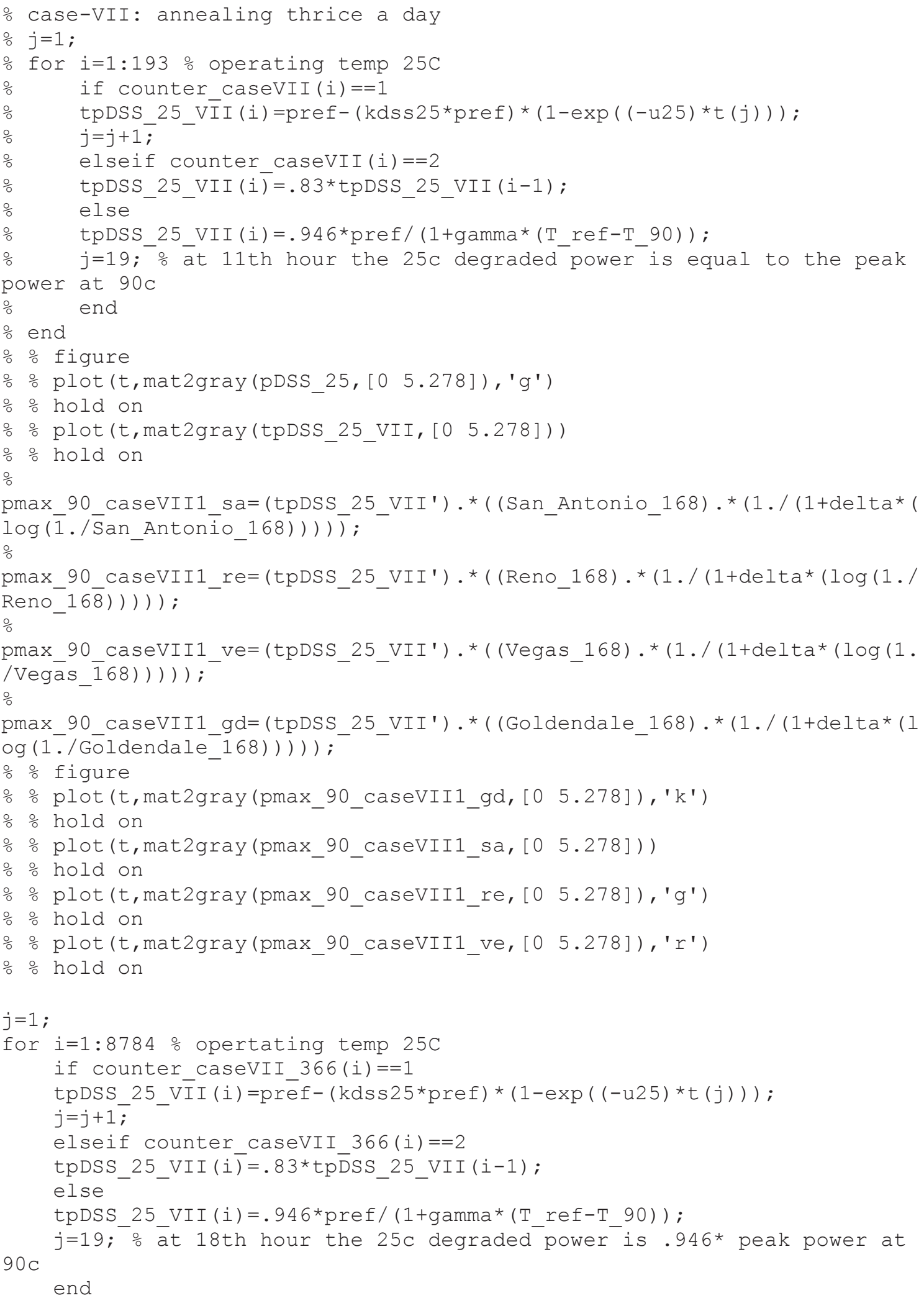




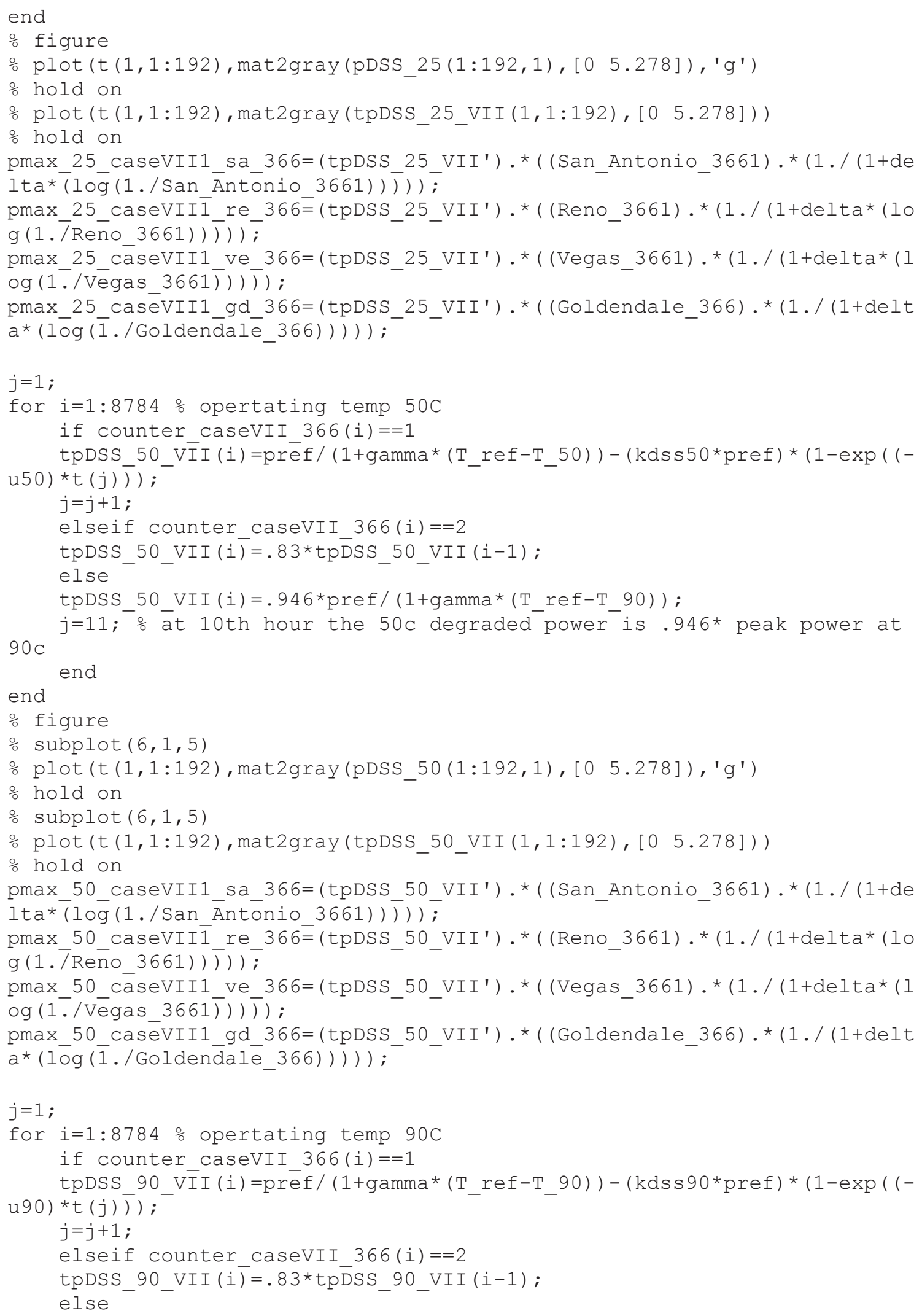




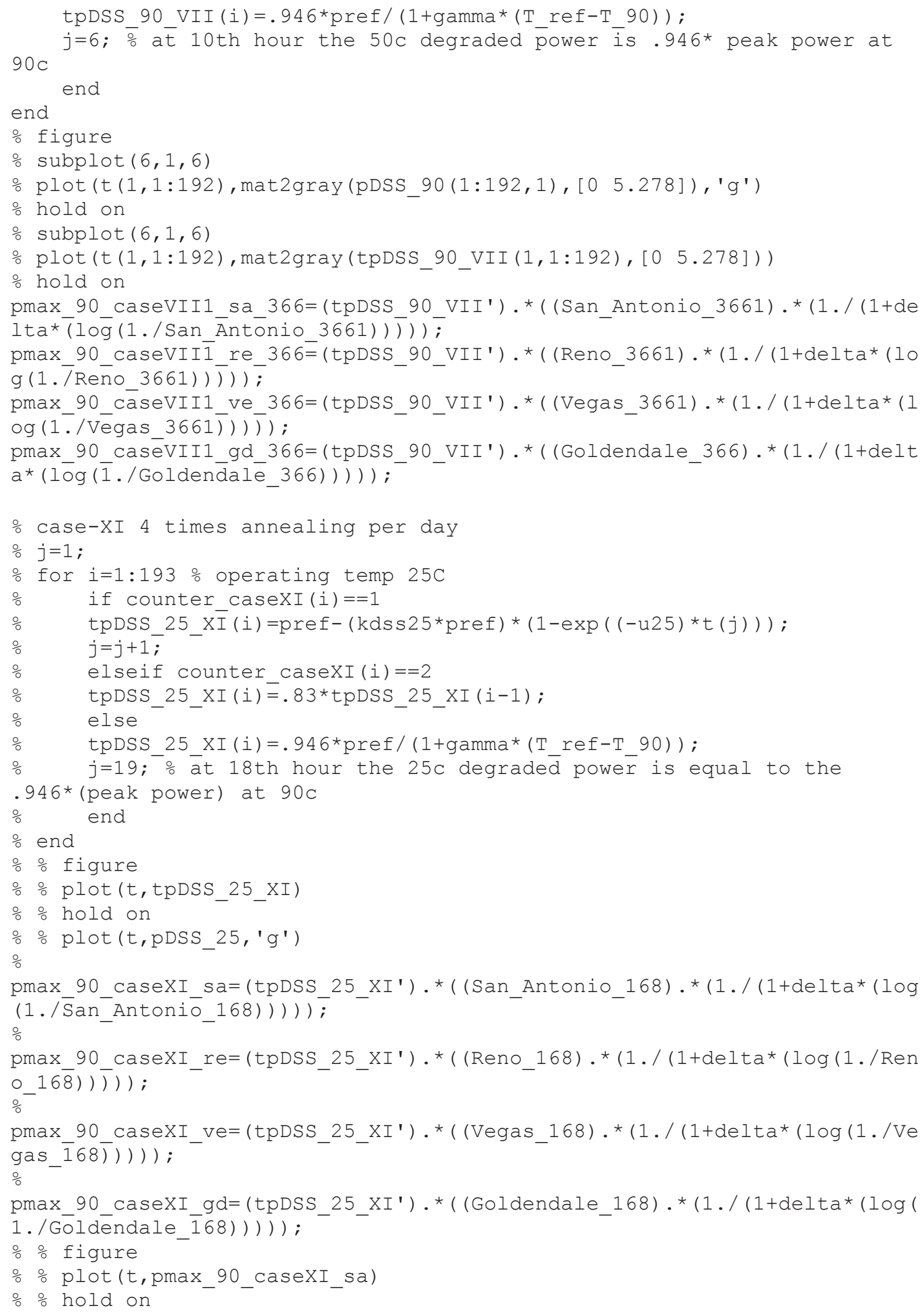




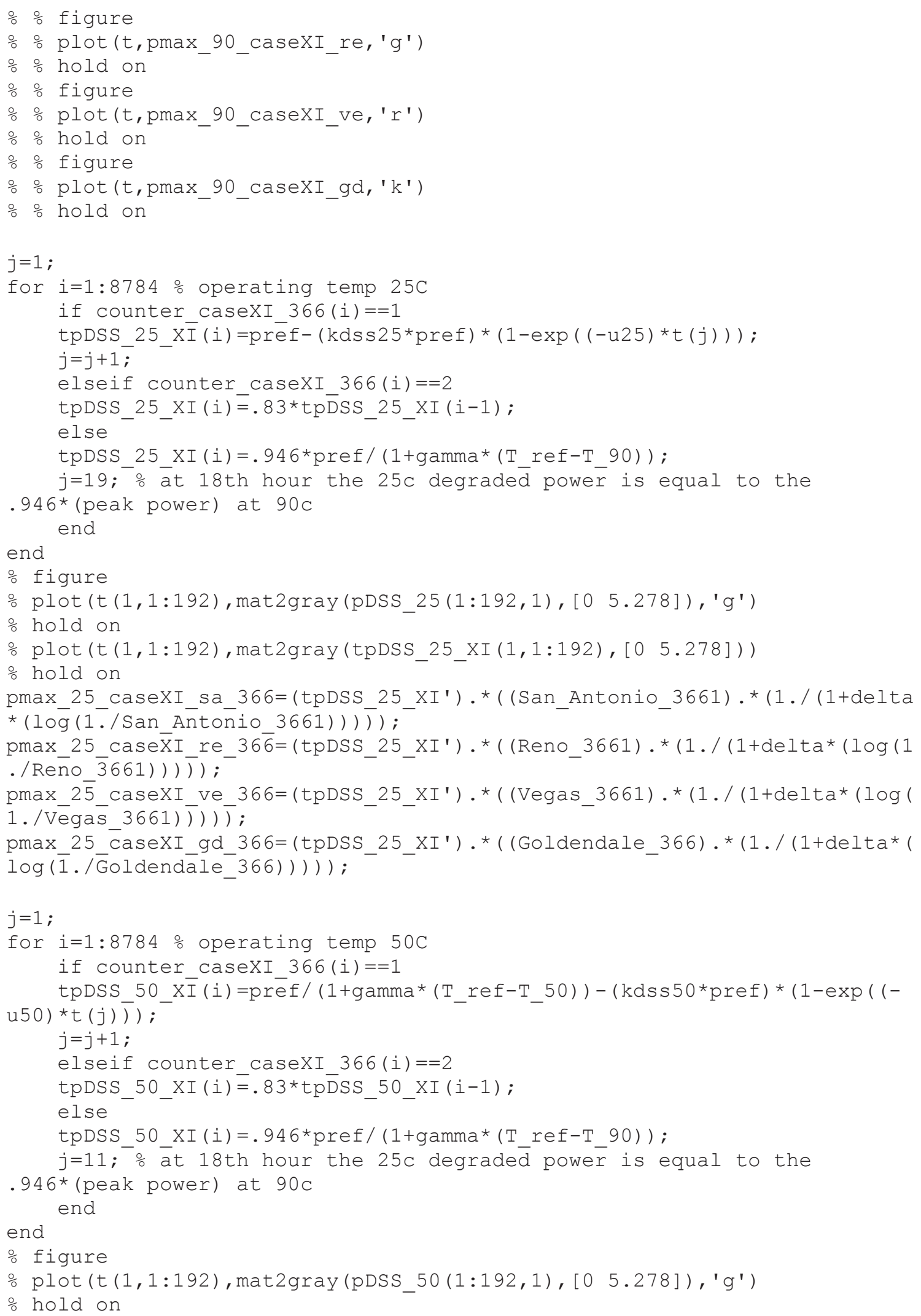




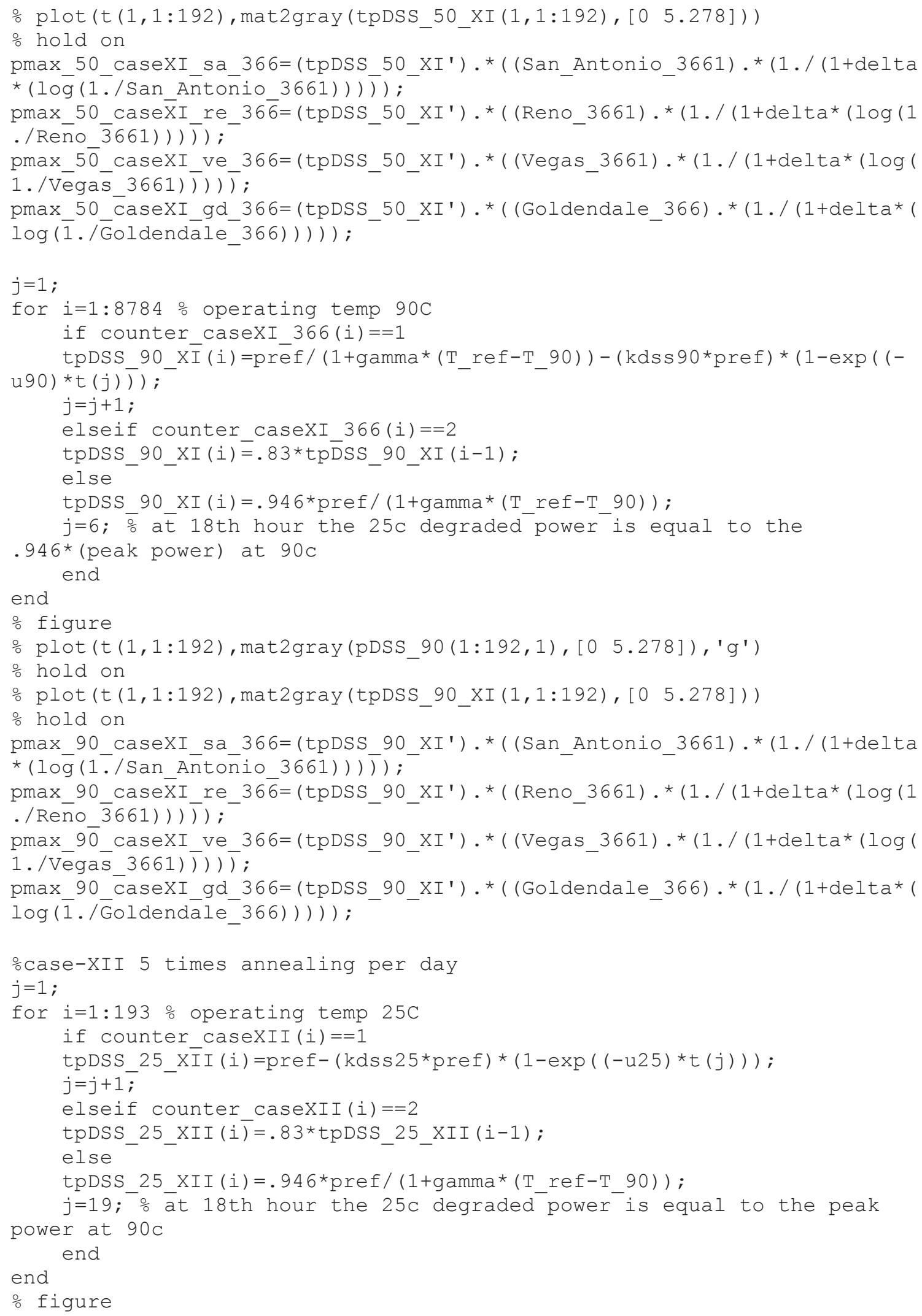




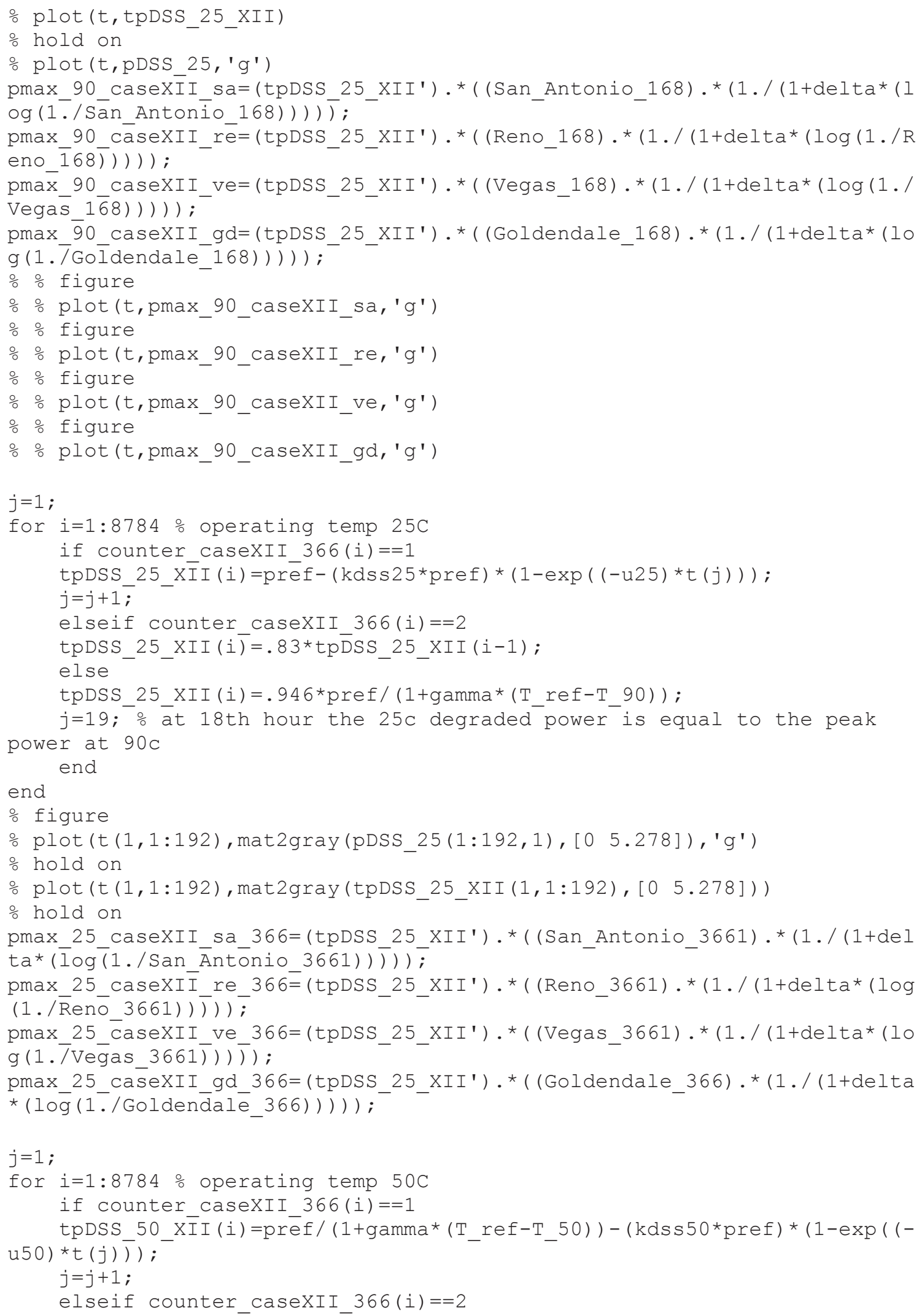




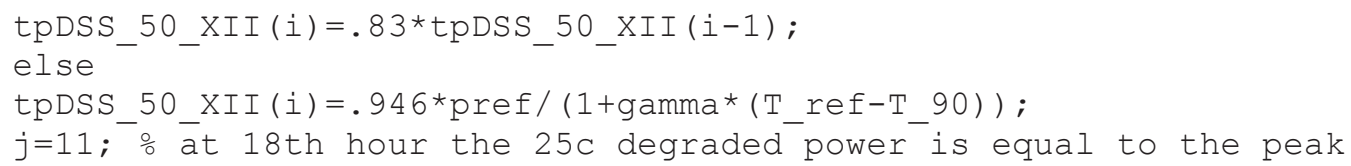




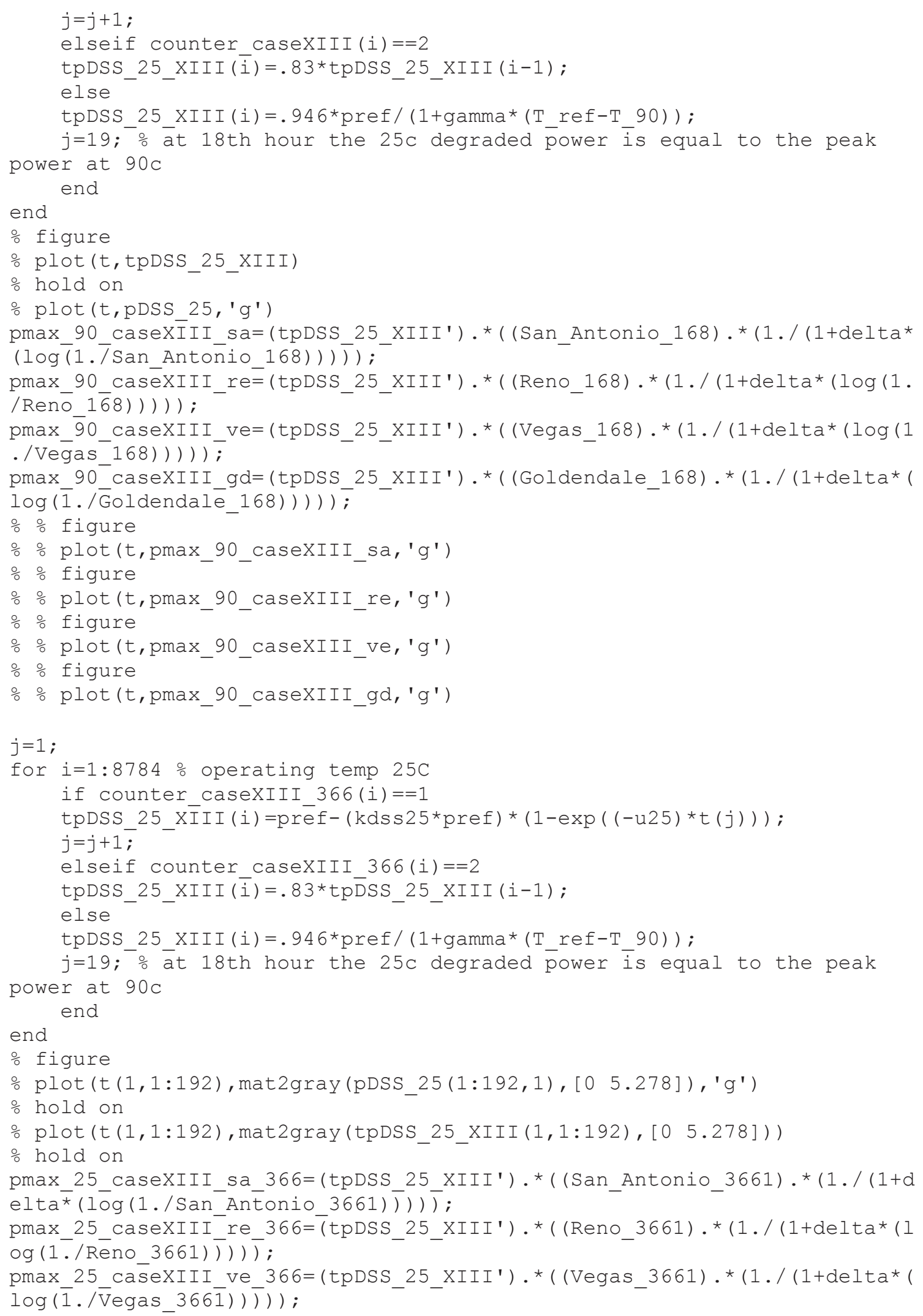




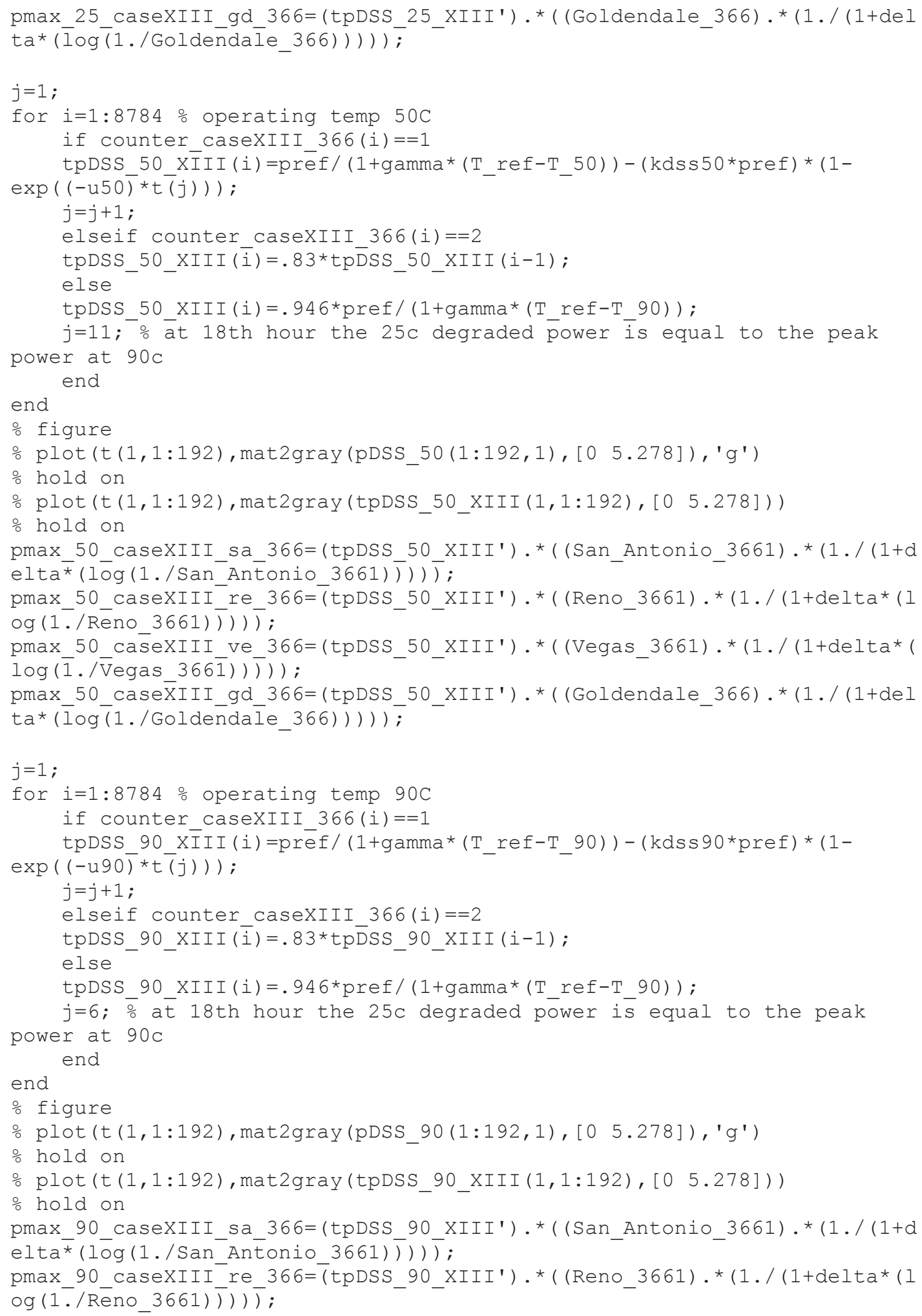




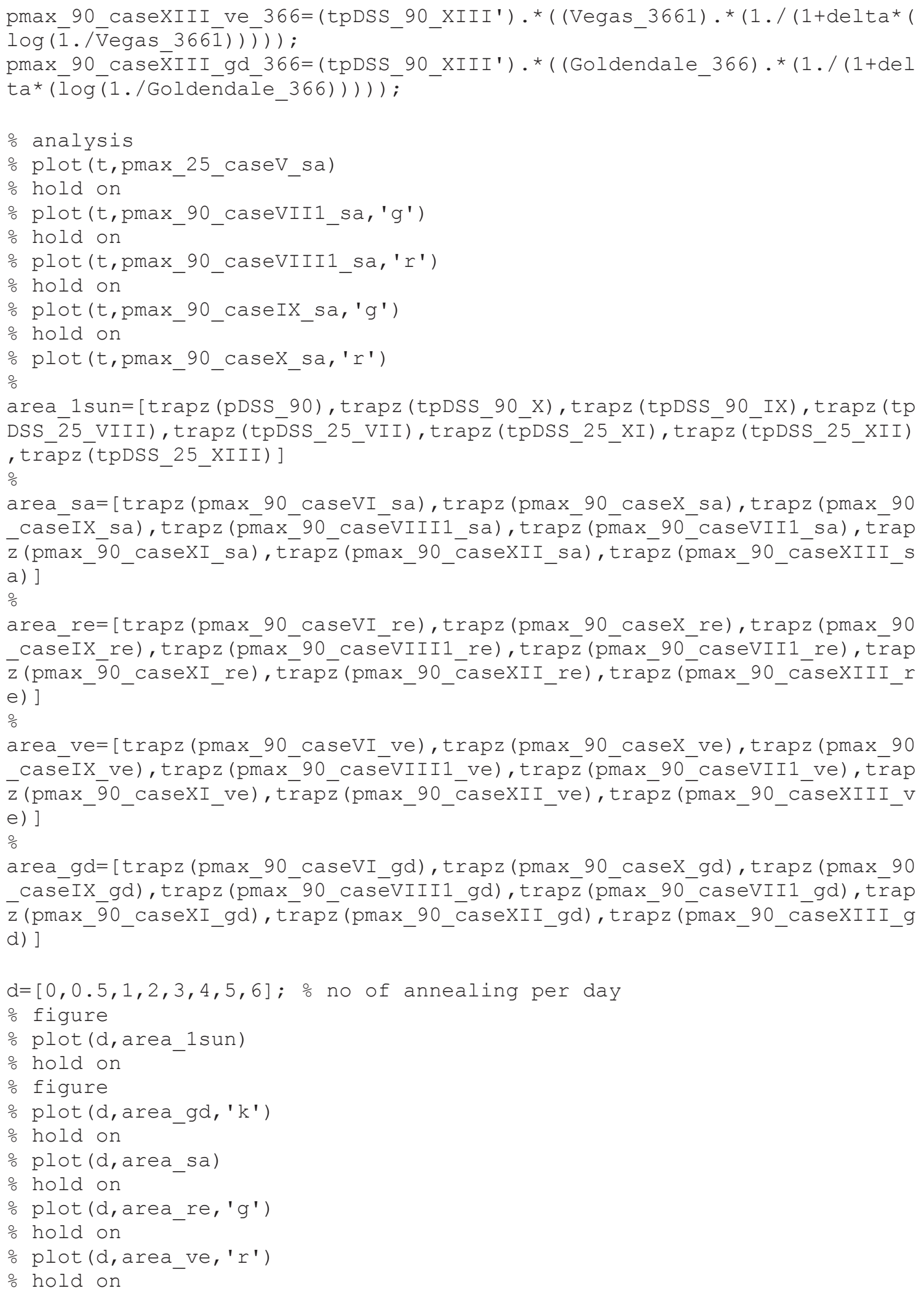


area_1sun 366 $[$ trapz (pDSS_90), trapz (tpDSS_90_X), trapz (tpDSS_90_IX), trap

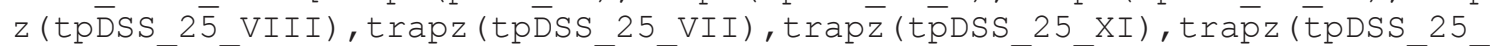
XII), trāpz (tpDSS_25_XIII)];

area_sa_366=[trap̄z (p̄max_90_caseVI_sa_366), trapz (pmax_90_casex_sa_366), t rapz (pmax_90_caseIX_sa_366), trapz (pmax_90_caseVIII1_sa_ $\overline{3} 66)$, trapz (pmax

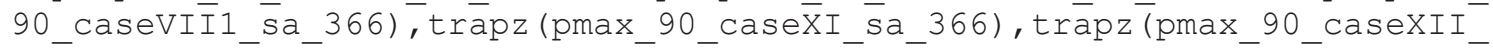
sa_366), trap̄z ( ${ }^{-} \max 990$ caseXIII_sa_366)];

arēa re 366=[trapz (pmax 90 casévI re 366), trapz (pmax 90 casex re 366), t

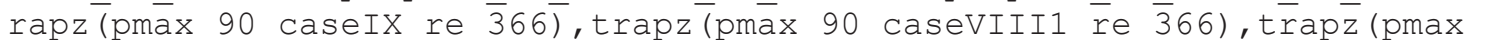

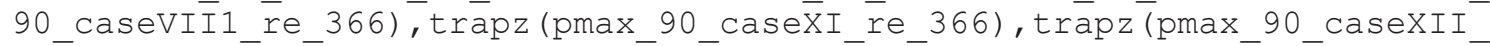
re_366), trapz (pmax_90_caseXIII_re_366)];

arēa ve 366=[trapz (pmax 90 casévI ve 366), trapz (pmax 90 casex ve 366), t rapz (pmāx 90 caseIX ve $\overline{3} 66 \overline{)}$, trapz (pmāx 90 caseVIIII ve $\overline{3} 66)$, t $\bar{r}$ rap $\bar{z}(\operatorname{pmax}$

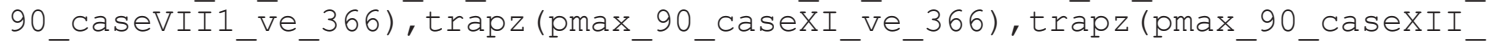
ve_366), trapz (pmax_90_caseXIII_ve_366)];

arēa_gd_366=[trapz (pmäx_90_casévI_-gd_366), trapz (pmax_90_casex_gd_366), t

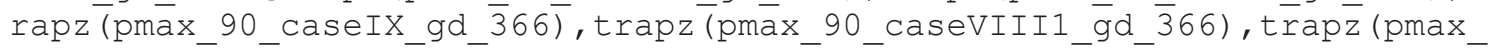

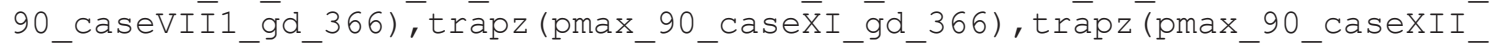

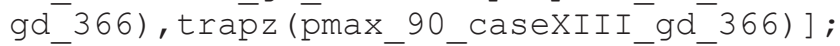

figure

\% plot (d,area_1sun_366)

\% hold on

o figure

\% plot (d, area gd 366, 'k')

o hold on

\% plot (d,area_sa_366)

hold on

\% plot (d,area_re_366, 'g')

hold on

\% $\operatorname{plot}(d$, area_ve_366, 'r')

\% hold on

area_1sun_366_25=[trapz (pDSS_25), trapz (tpDSS_25_X), trapz (tpDSS_25_IX), t

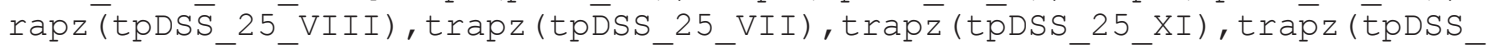
25 XII), trāpz (tpDSS_25_XIII)]

arēa sa 366 25=[trap̄z ( $\bar{p}$ max 25 caseV sa 366), trapz (pmax 25 casex sa 366)

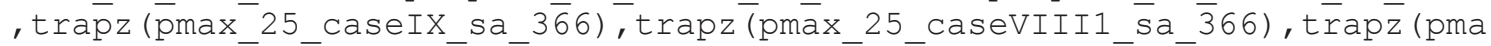

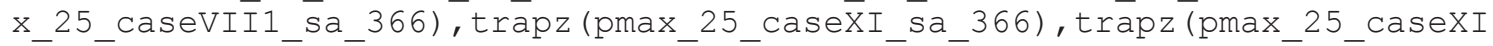
I_sa_366), trap̄z (p̄max_25_casexIII_sa_366)]

area_re_366_25=[trapz (pmax_25_caseV_re_366), trapz (pmax_25_casex_re_366)

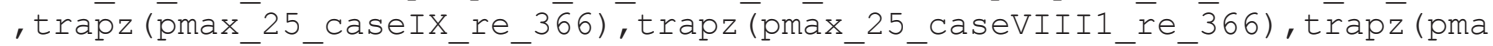

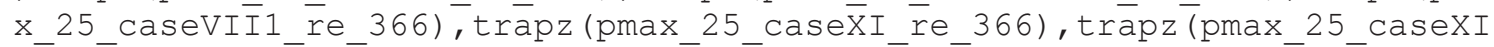
I_re_366), trap̄o (p̄max_25_casexIII_re_366)]

area_ve_366_25=[trapz̄ (pmax_25_casev_ve_366), trapz (pmax_25_casex_ve_366) , trapz (pmax_25_caseIX_ve_366), trapz (pmax_25_caseVIII1_ve_

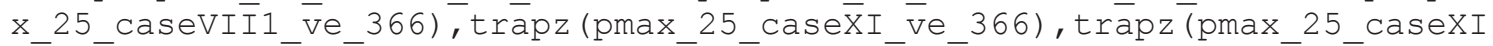

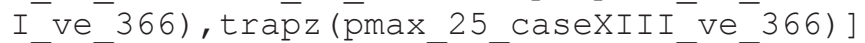

area_gd_366_25=[trapz (pmax_25_casev_od 366), trapz (pmax 25 casex gd 366)

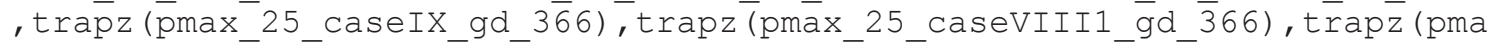

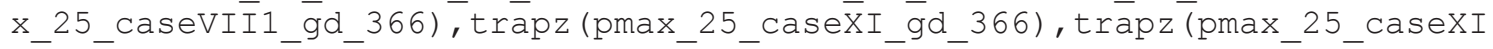
I_gd_366), trapz (pmax_25_caseXIII_gd_366)]

area_1sun_366_25=areā_1sun_366_2 $\overline{5} / 1 \overline{0} 00000$;

area_sa_3 $\overline{6} 6$ _2 $\overline{5}=$ area_sa_366_25/1000000;

area_re_366_25=area_re_366_25/1000000; 


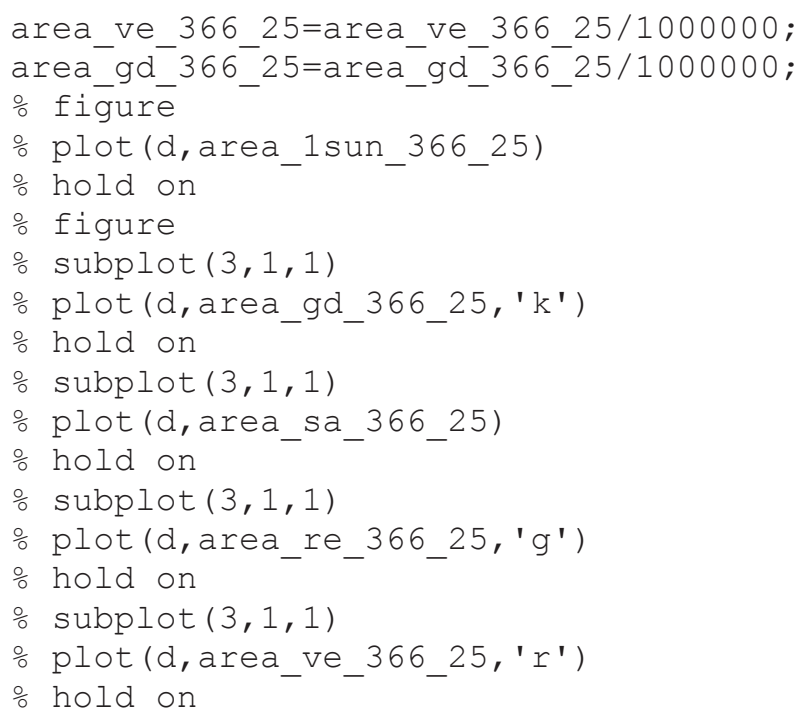




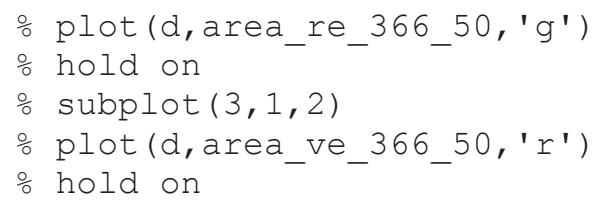

area_1sun_366_90=[trapz (pDSS_90), trapz (tpDSS_90_X), trapz (tpDSS_90_IX), t

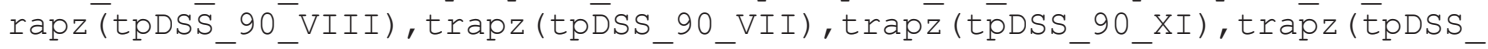
90_XII), trapz(tpDSS_90_XIII)]

aréa_sa_366_90=[trap̄z (p̄max_90_caseVI_sa_366), trapz (pmax_90_casex_sa_366

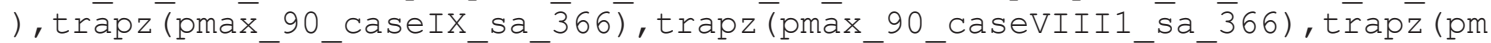
ax_90_caseVIİ_sa_366), trāpz (pmax_90_caseX̃I_sa_366), trapz (pmax_90_caseX II_sa_366), trapz (pmax_90_casexIII_sa_366)]

arēa re 366 90=[trapz (pmax 90_casévI re_366), trapz (pmax_90 casex_re 366

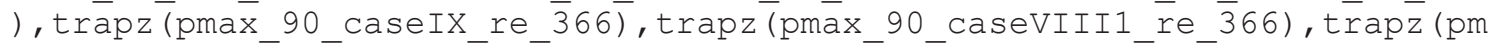

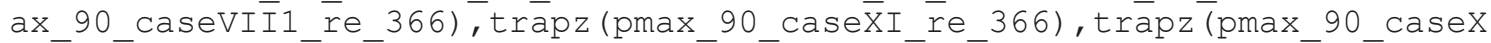
II_re_366), trapz (p̄max_90_casexIII_re_366)]

aréa_ve_366_90=[trapz (pmax_90_casēvI_ve_366), trapz (pmax_90_casex_ve_366

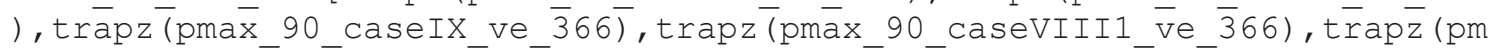

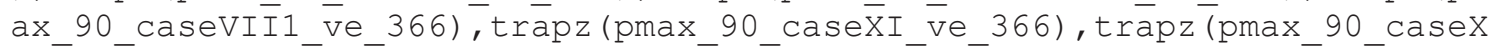
II_ve_366), trapz (pmax_90_casexIII_ve_366)]

aréa_gd_366_90=[trapz (pmax_90_casévI_gd_366), trapz (pmax_90_casex_gd_366

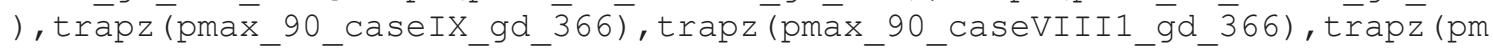

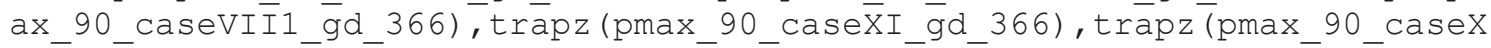
II_gd-366), trapz (p̄max_90_caseXIII-gd-366) ] 


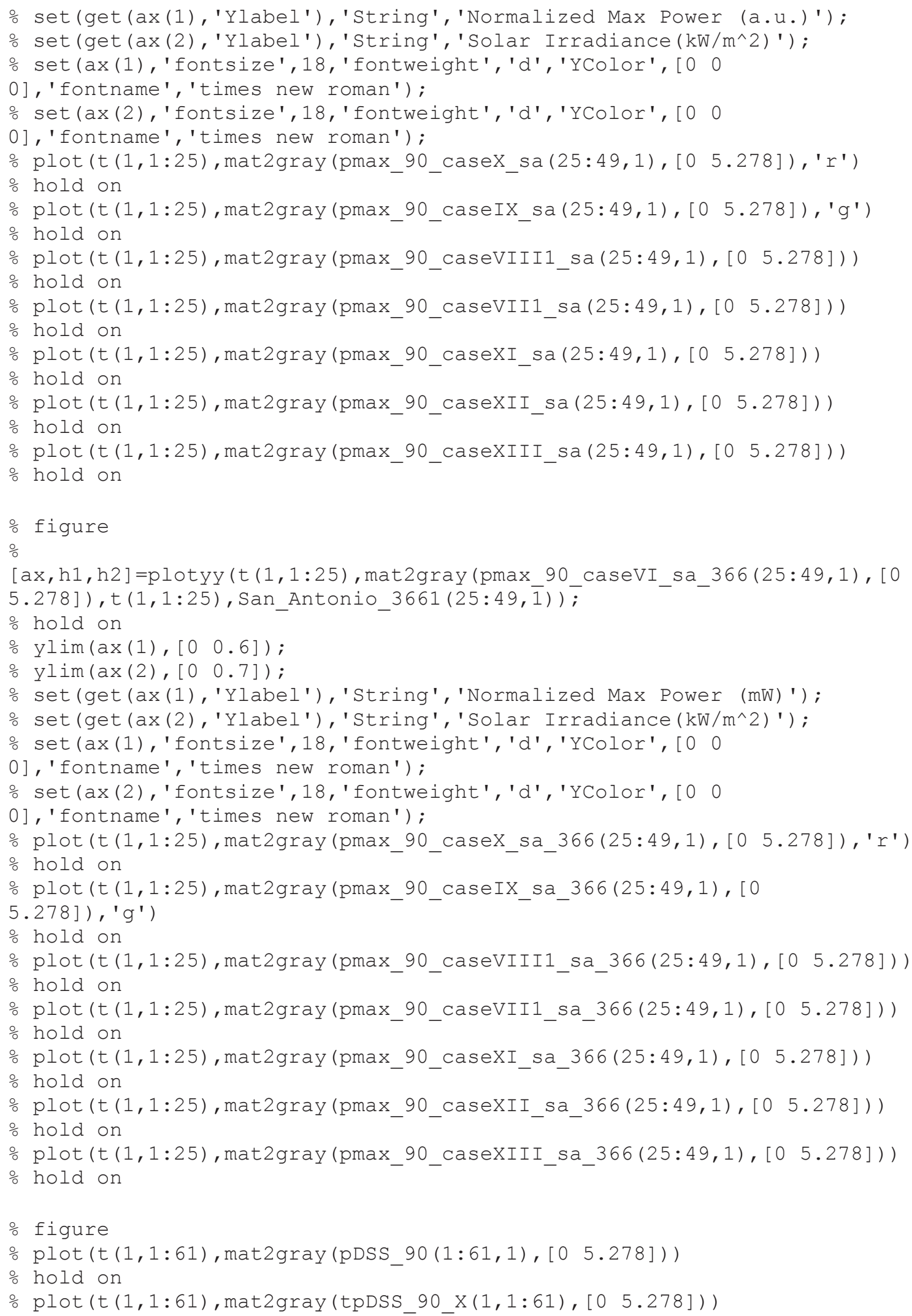




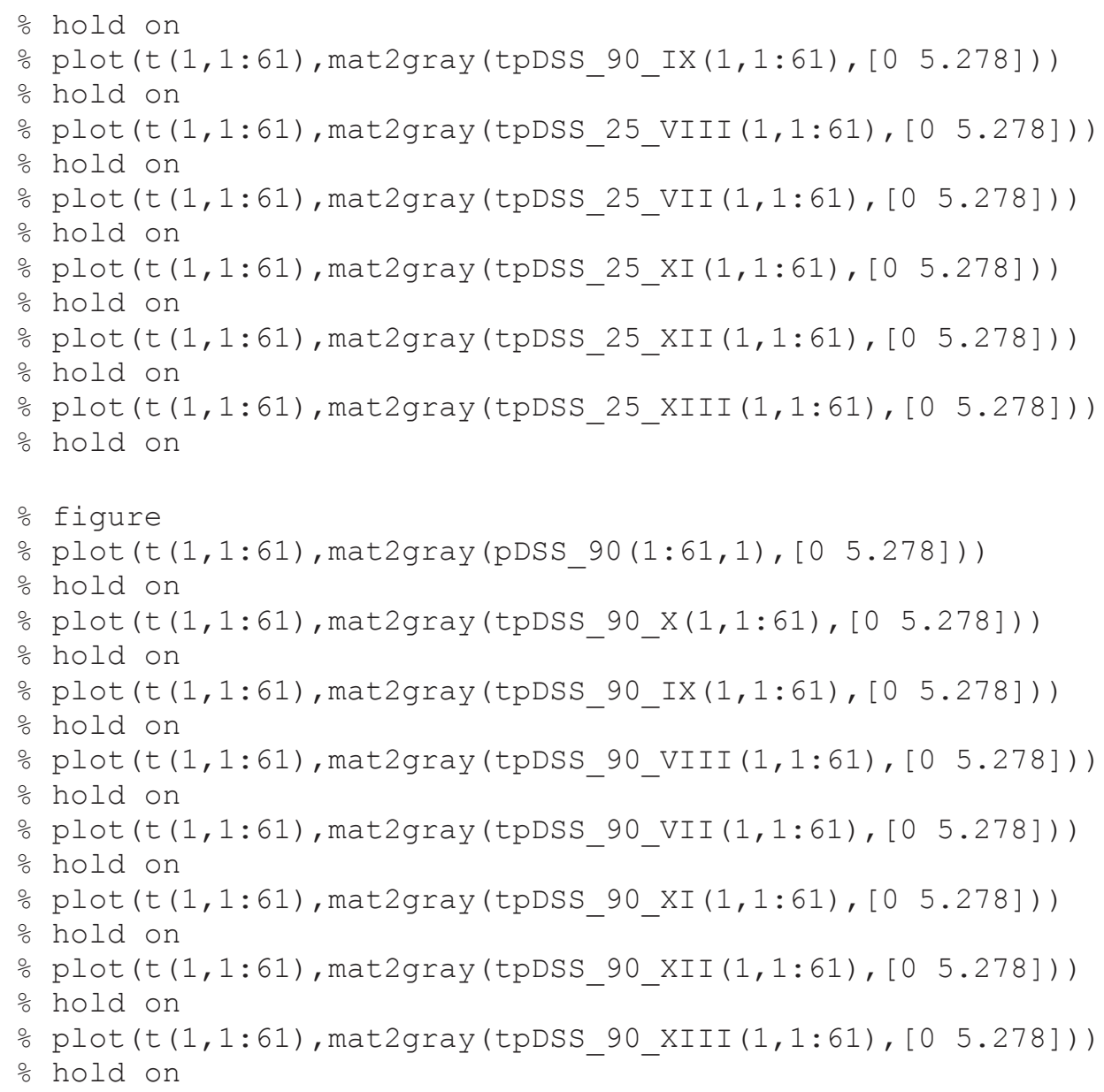




\section{Appendix II}

\section{Program Code: Outdoor Temperature Simulation}

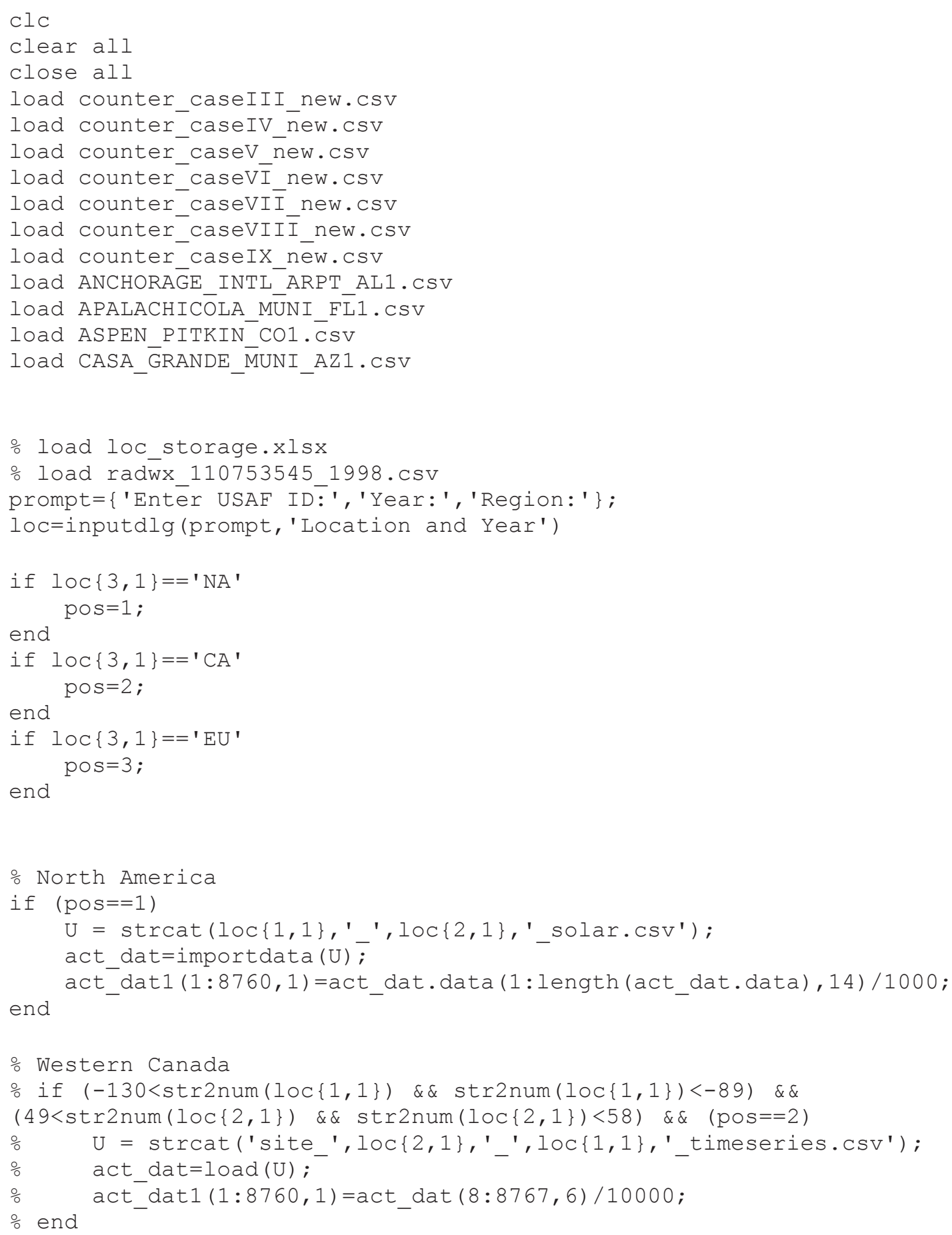




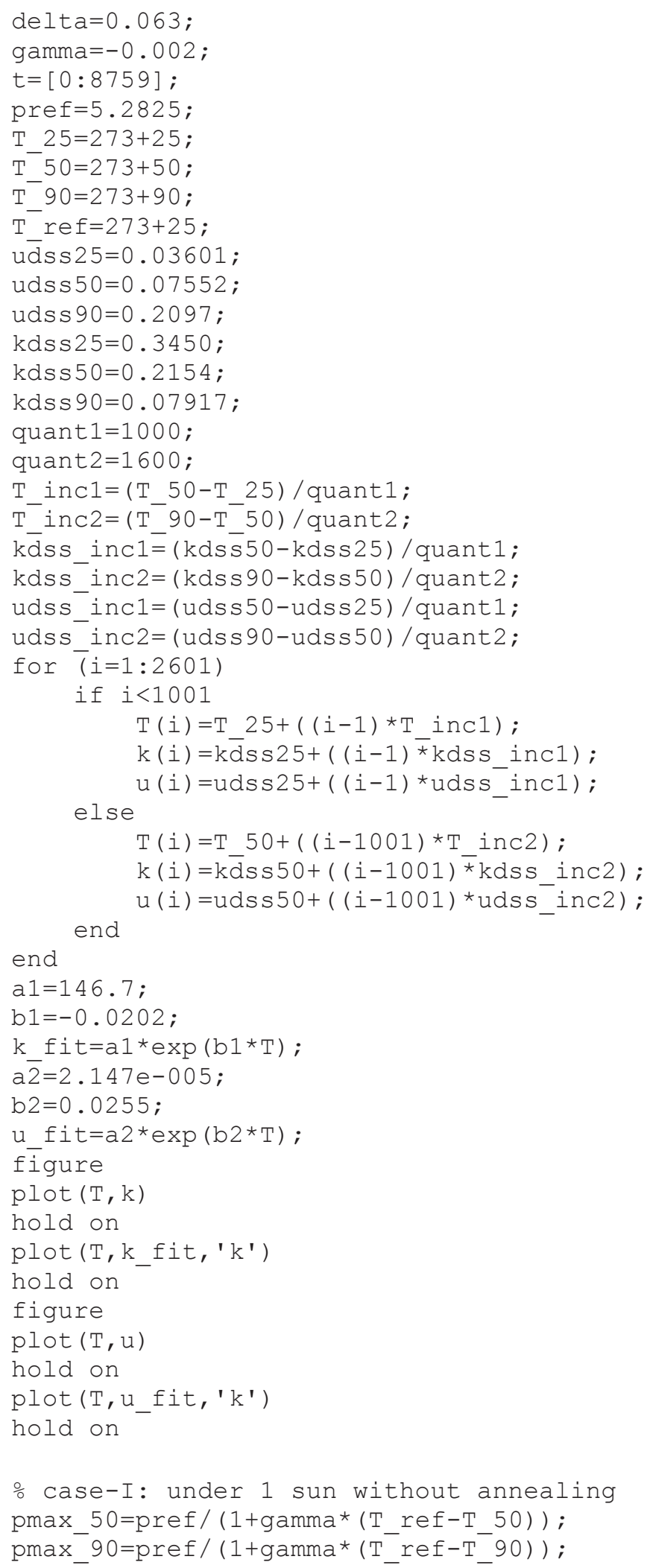




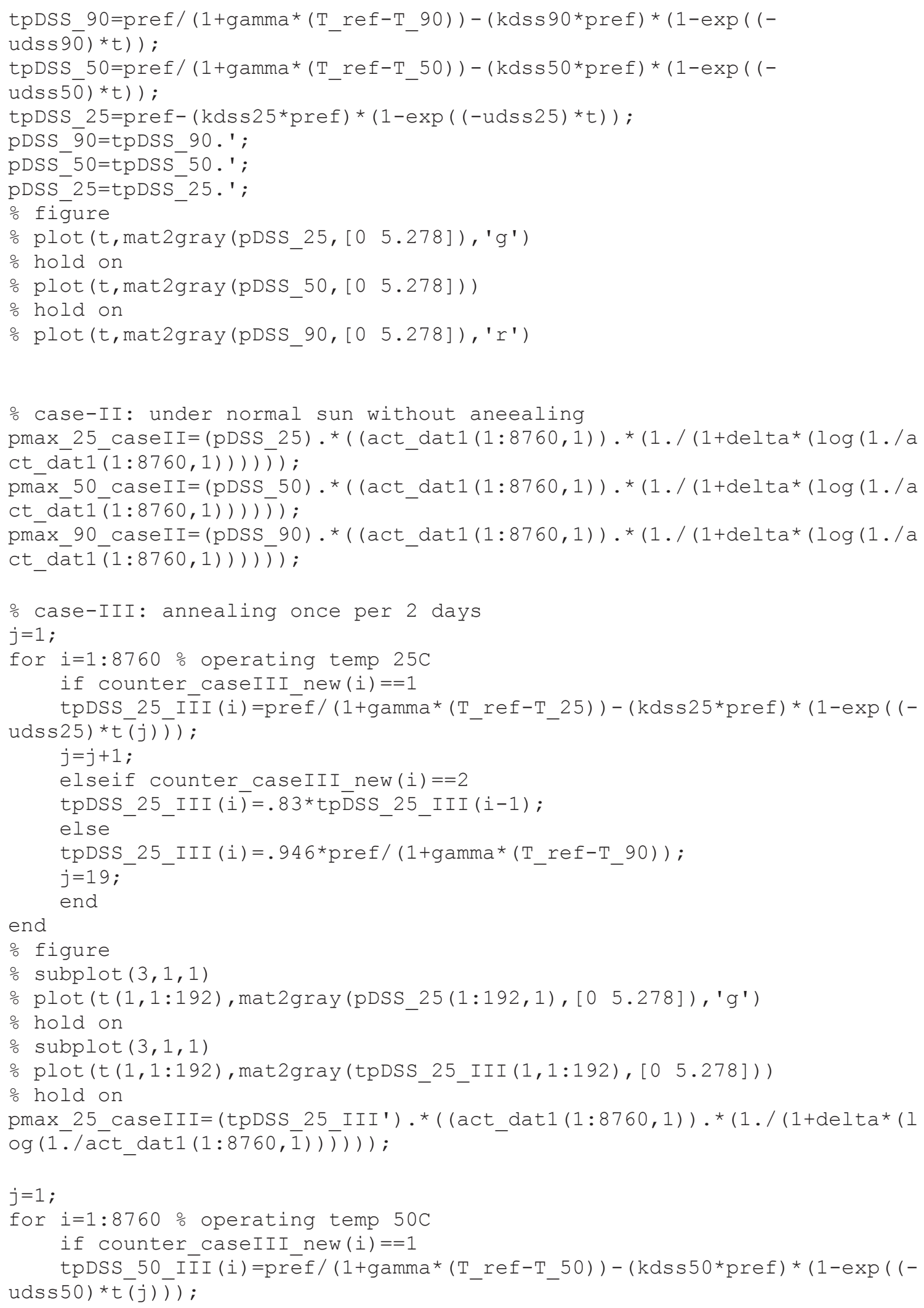




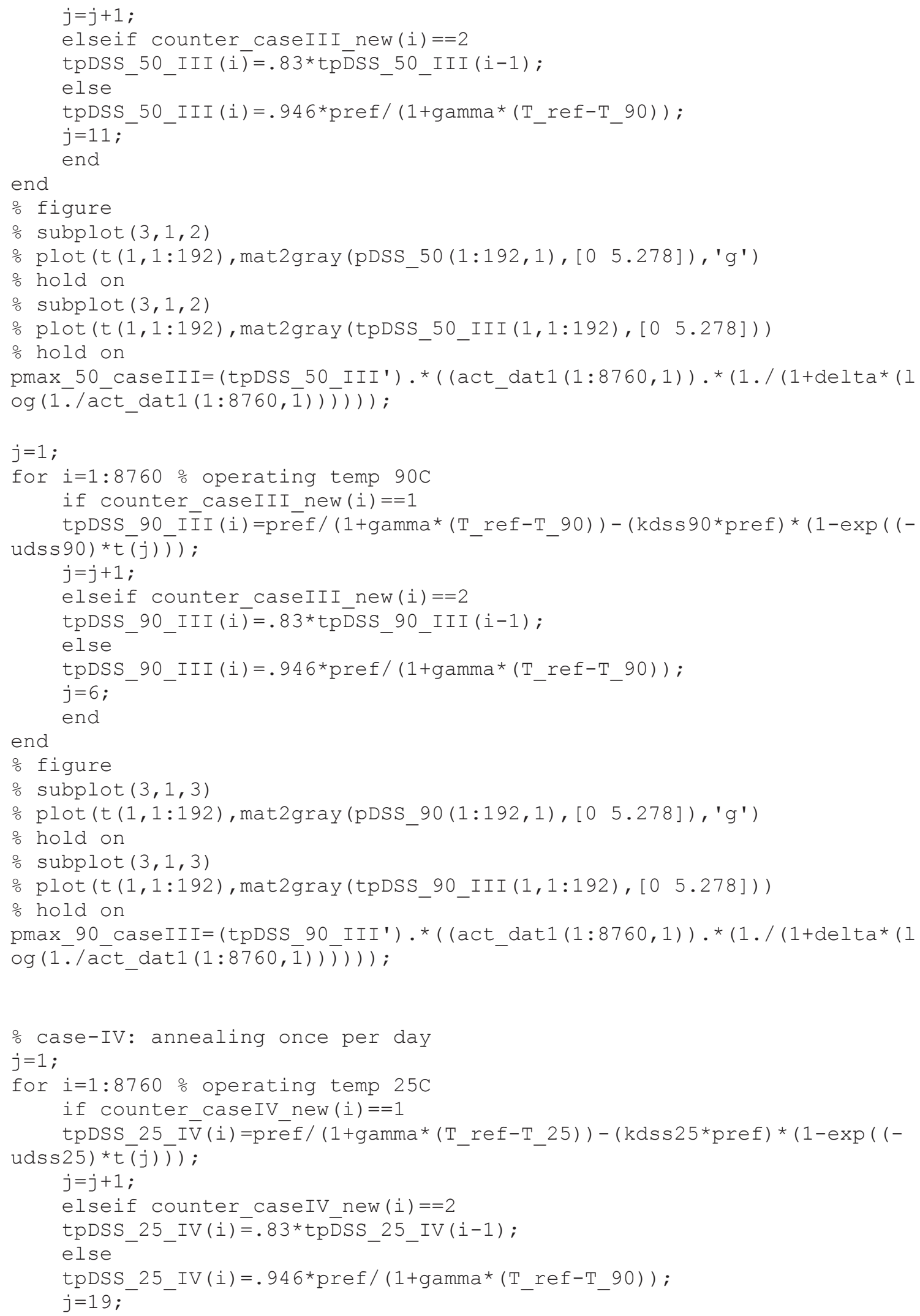




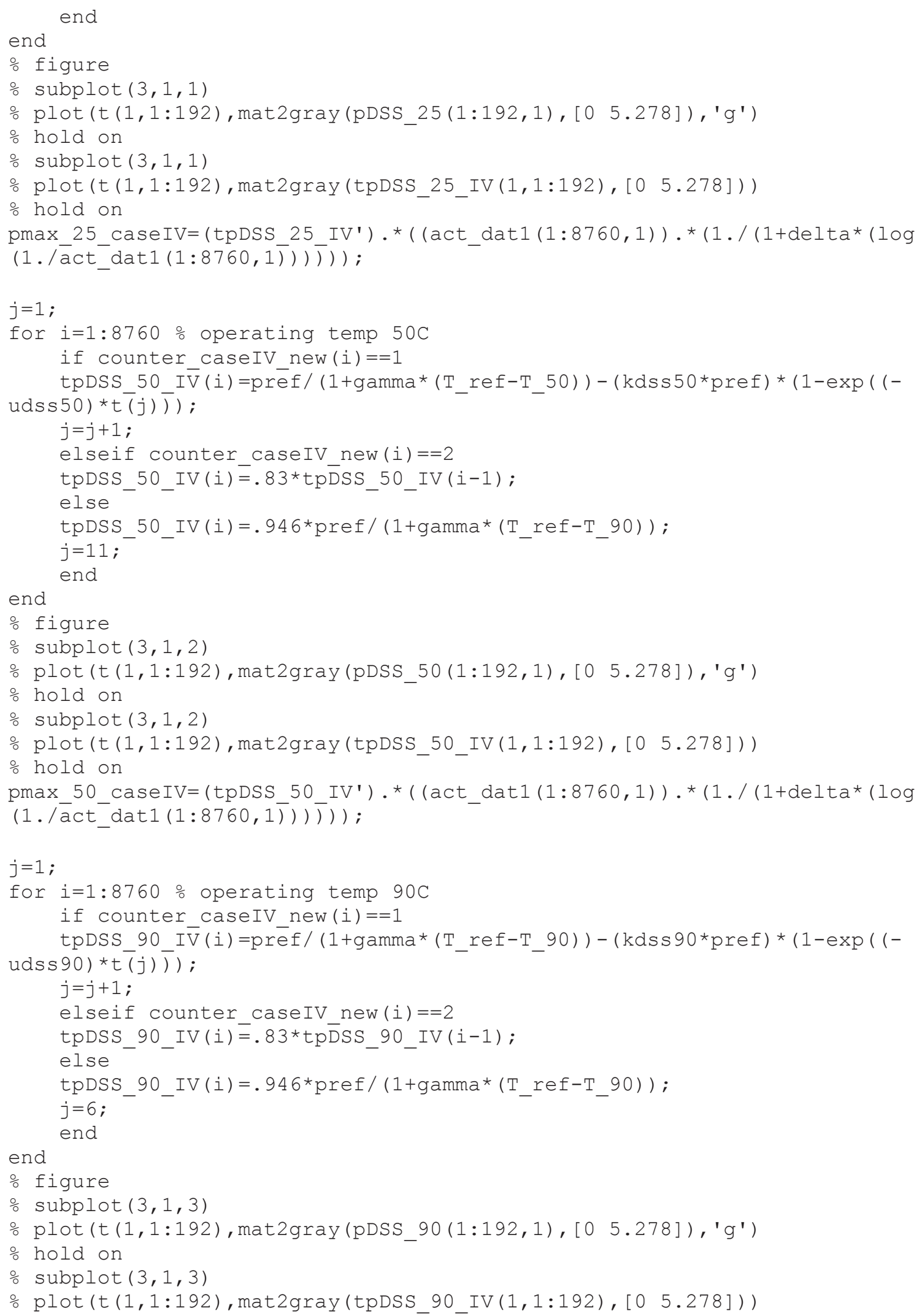




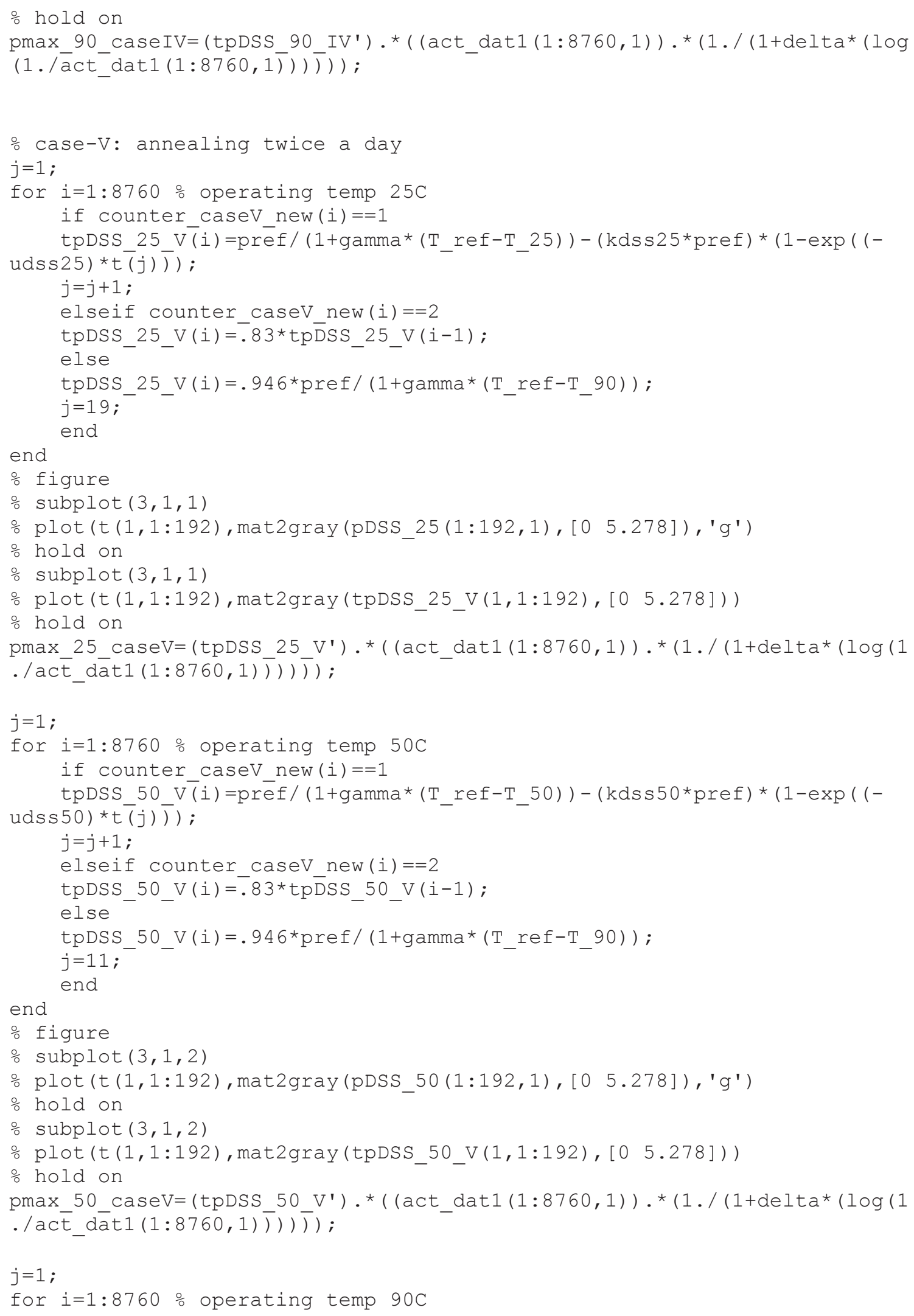




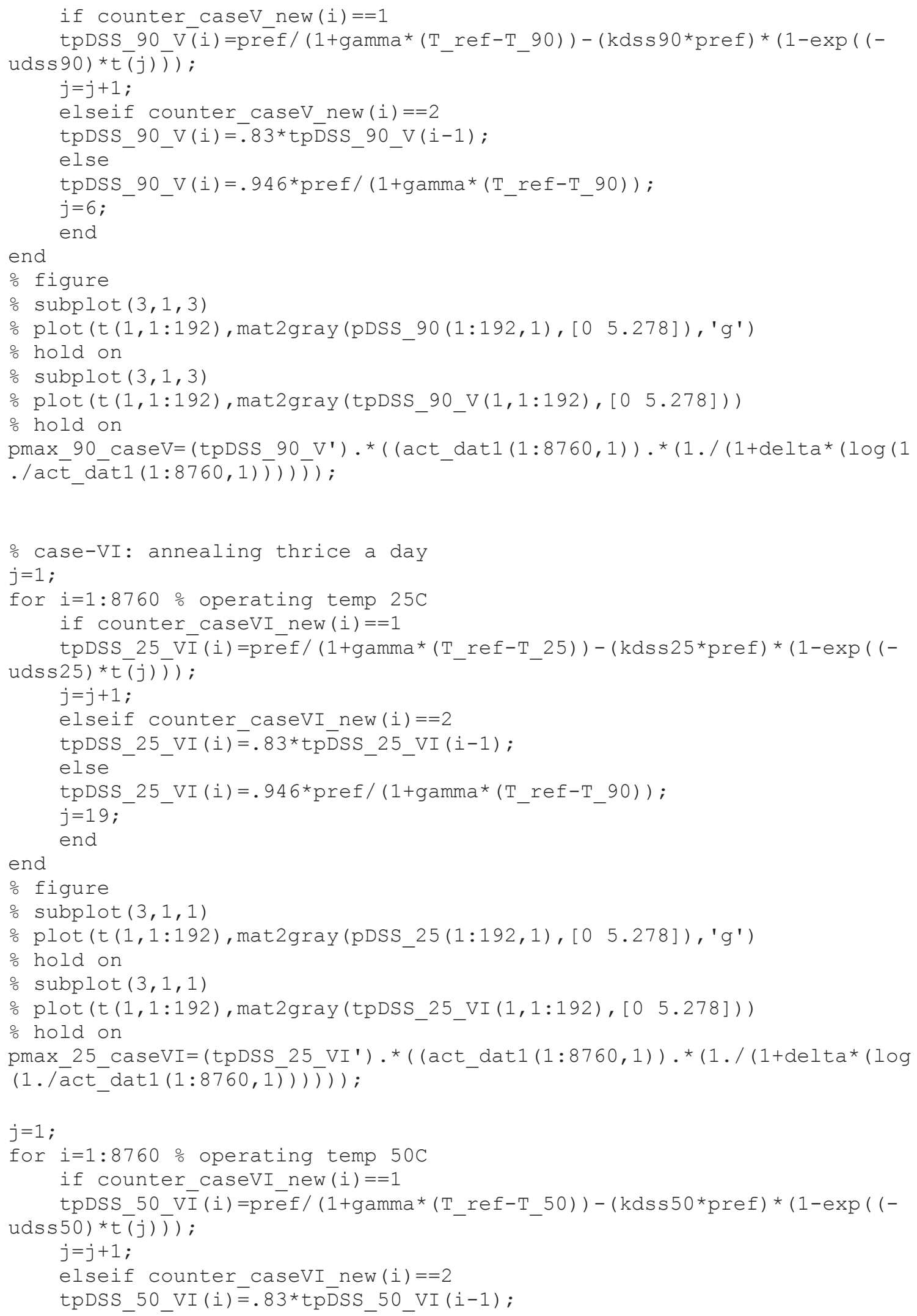




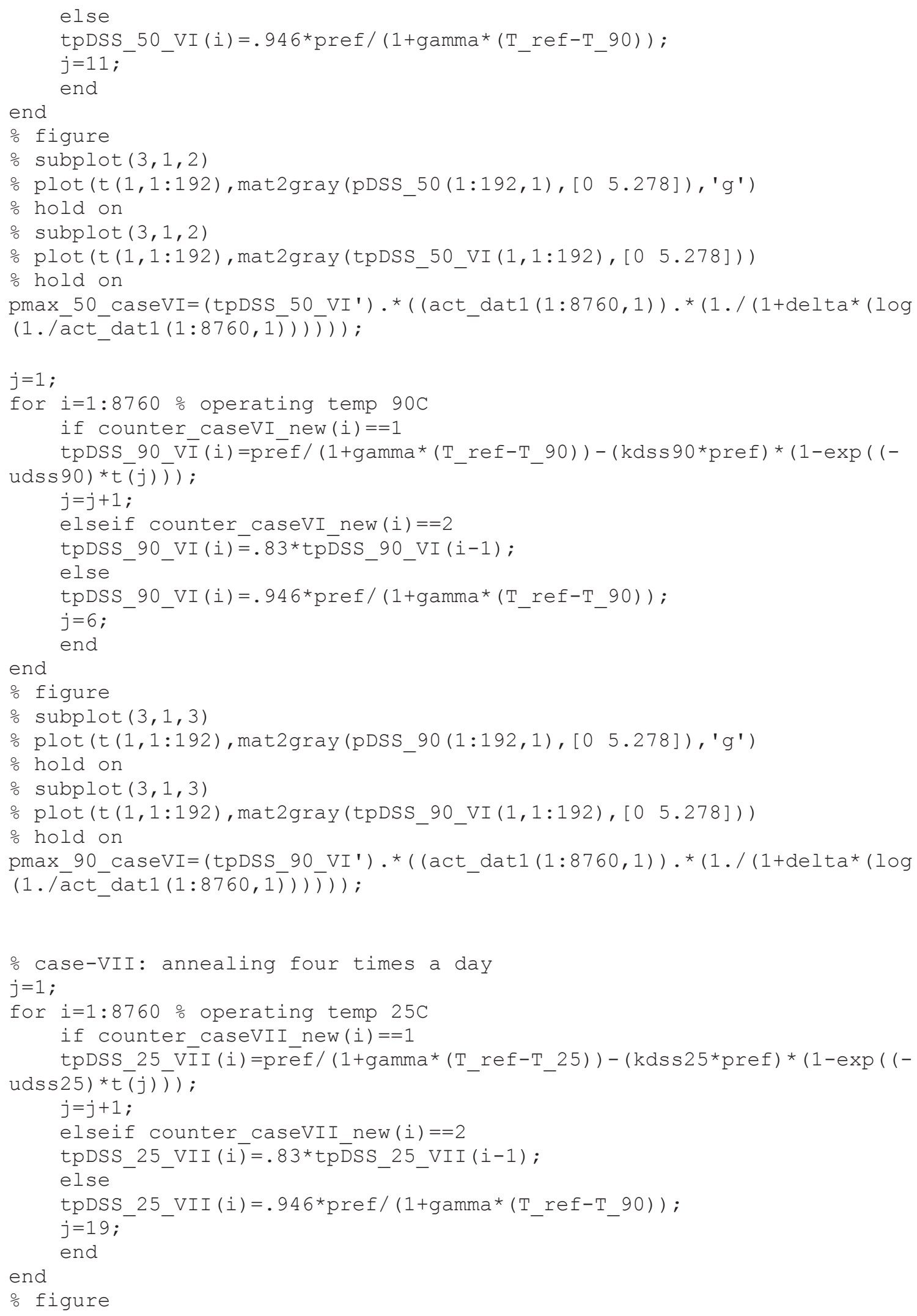




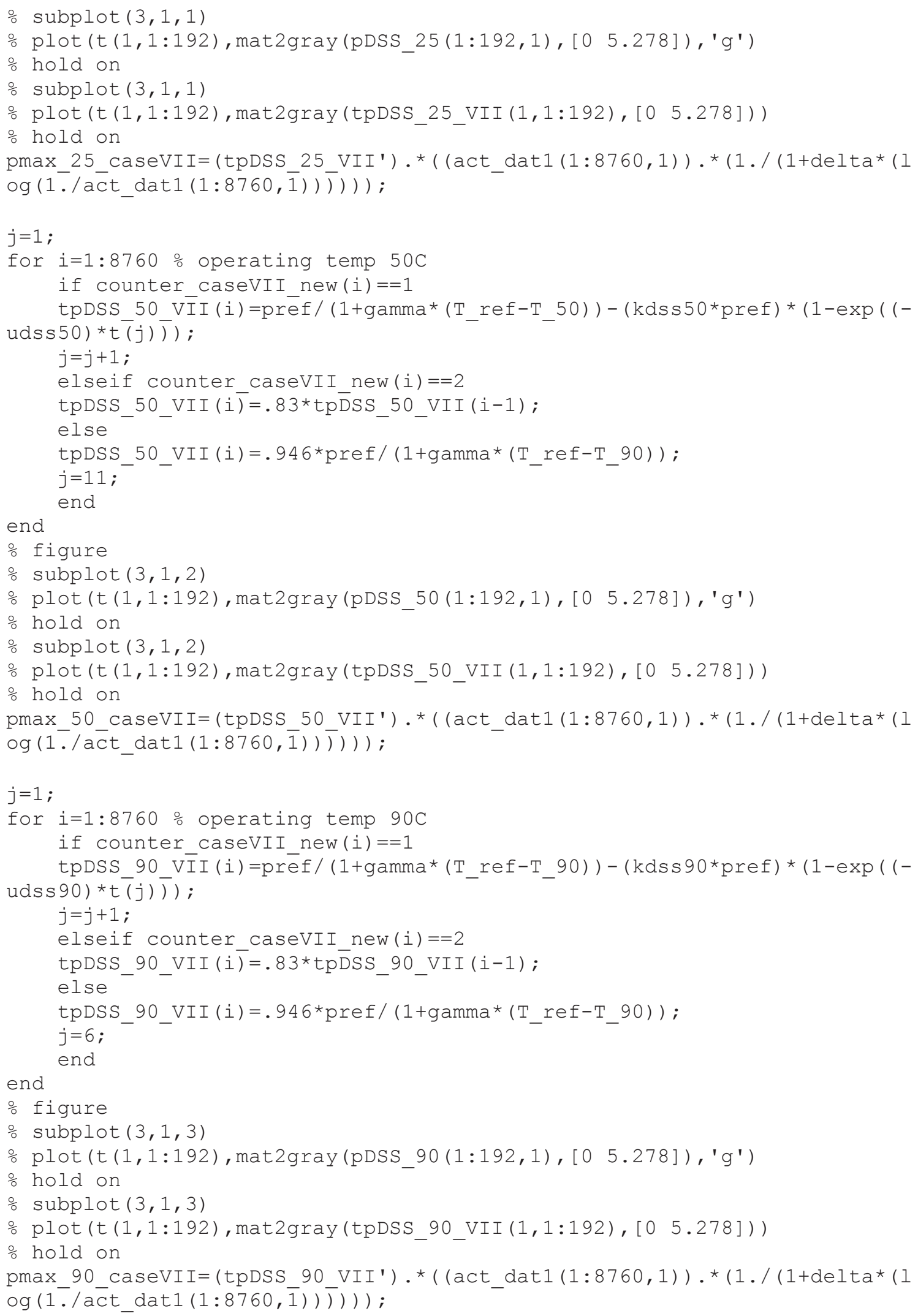




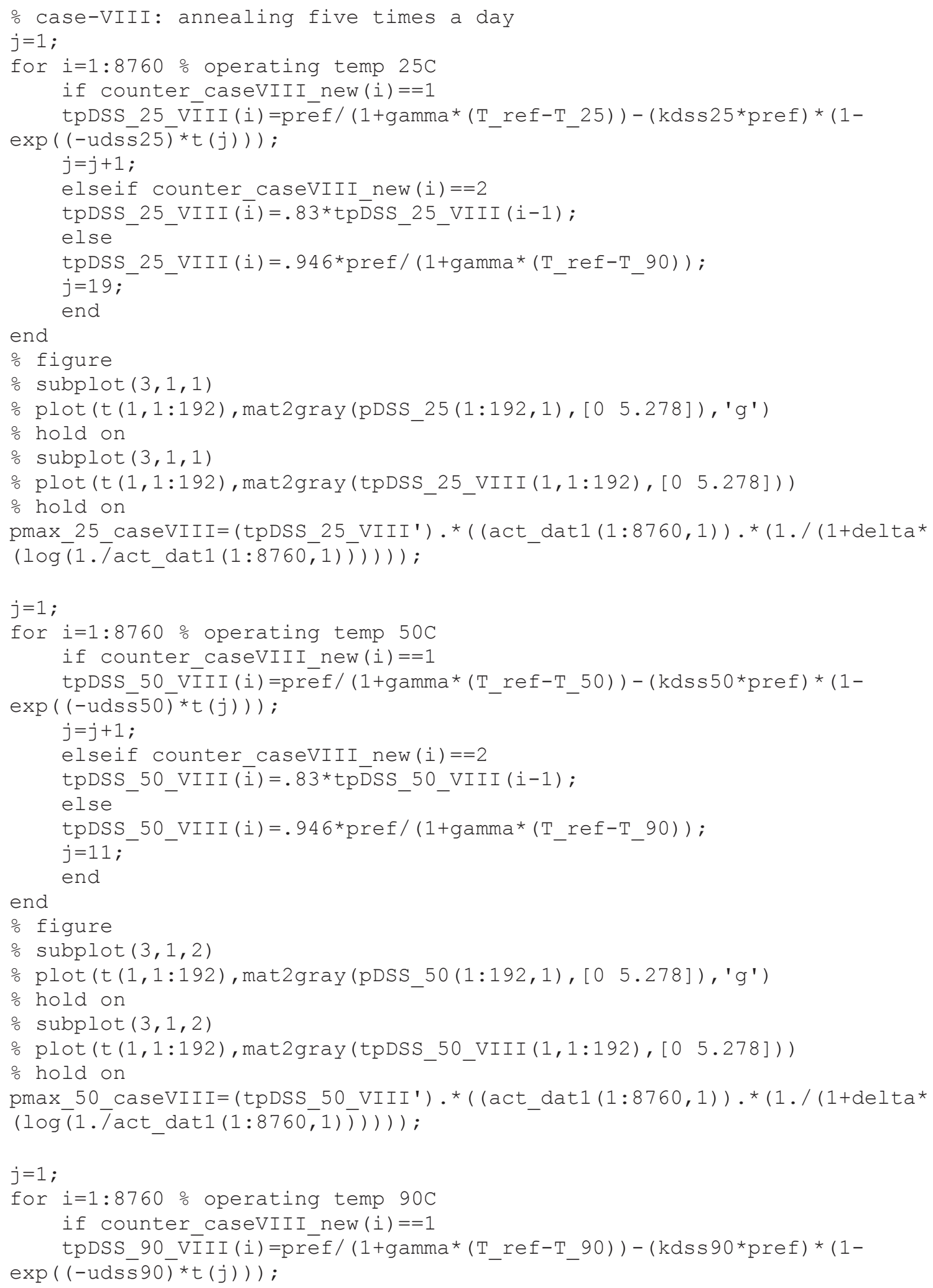




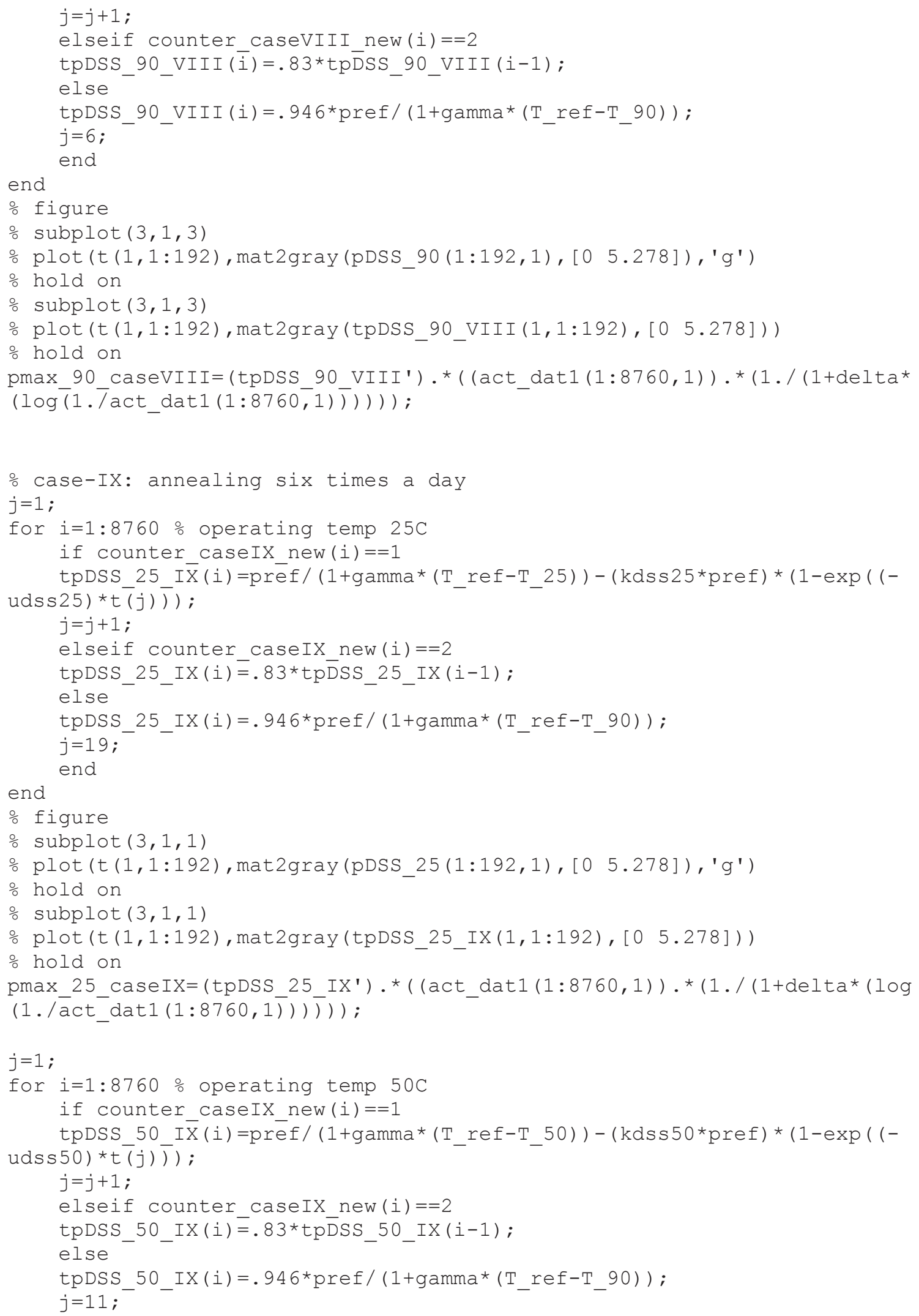




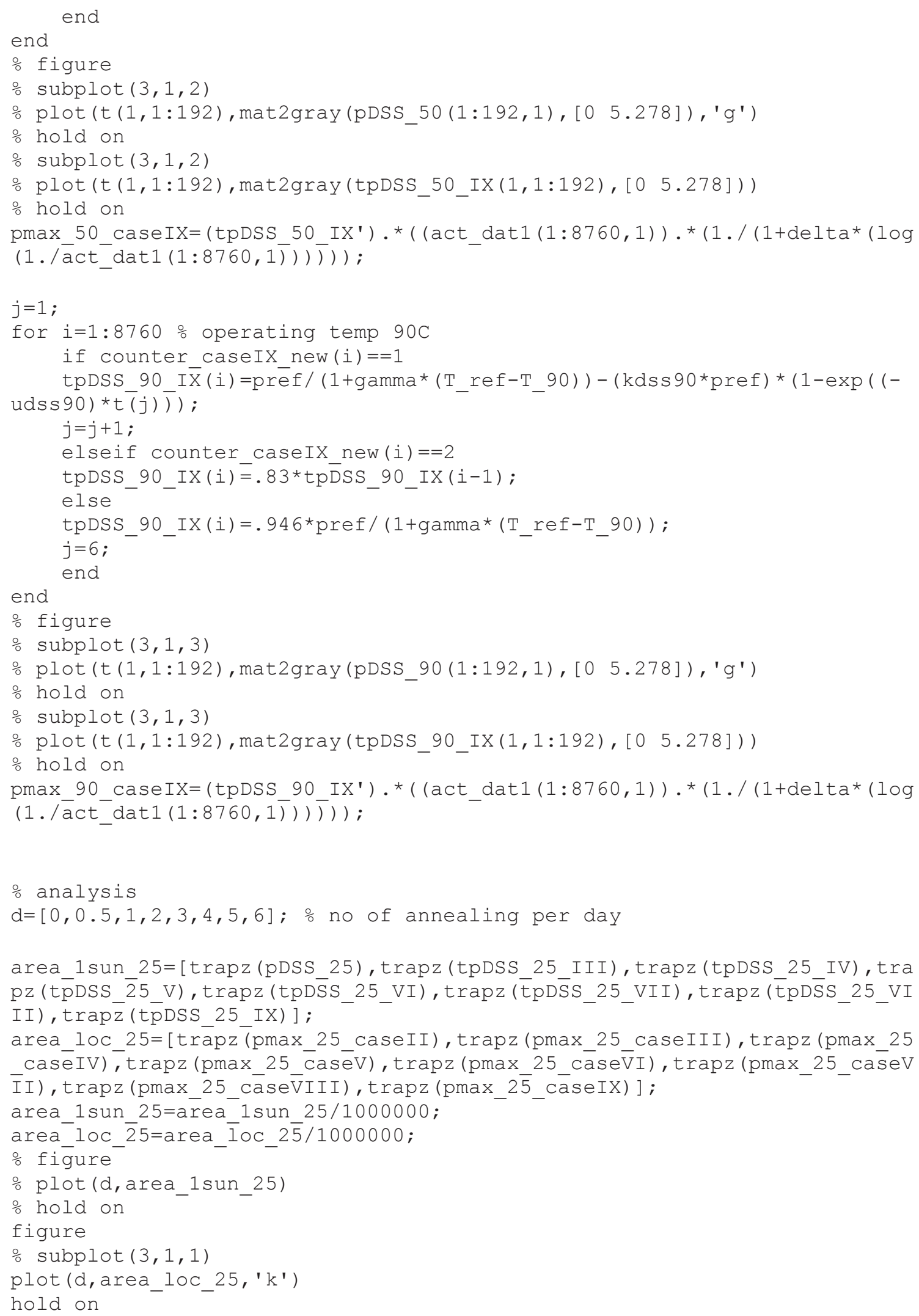




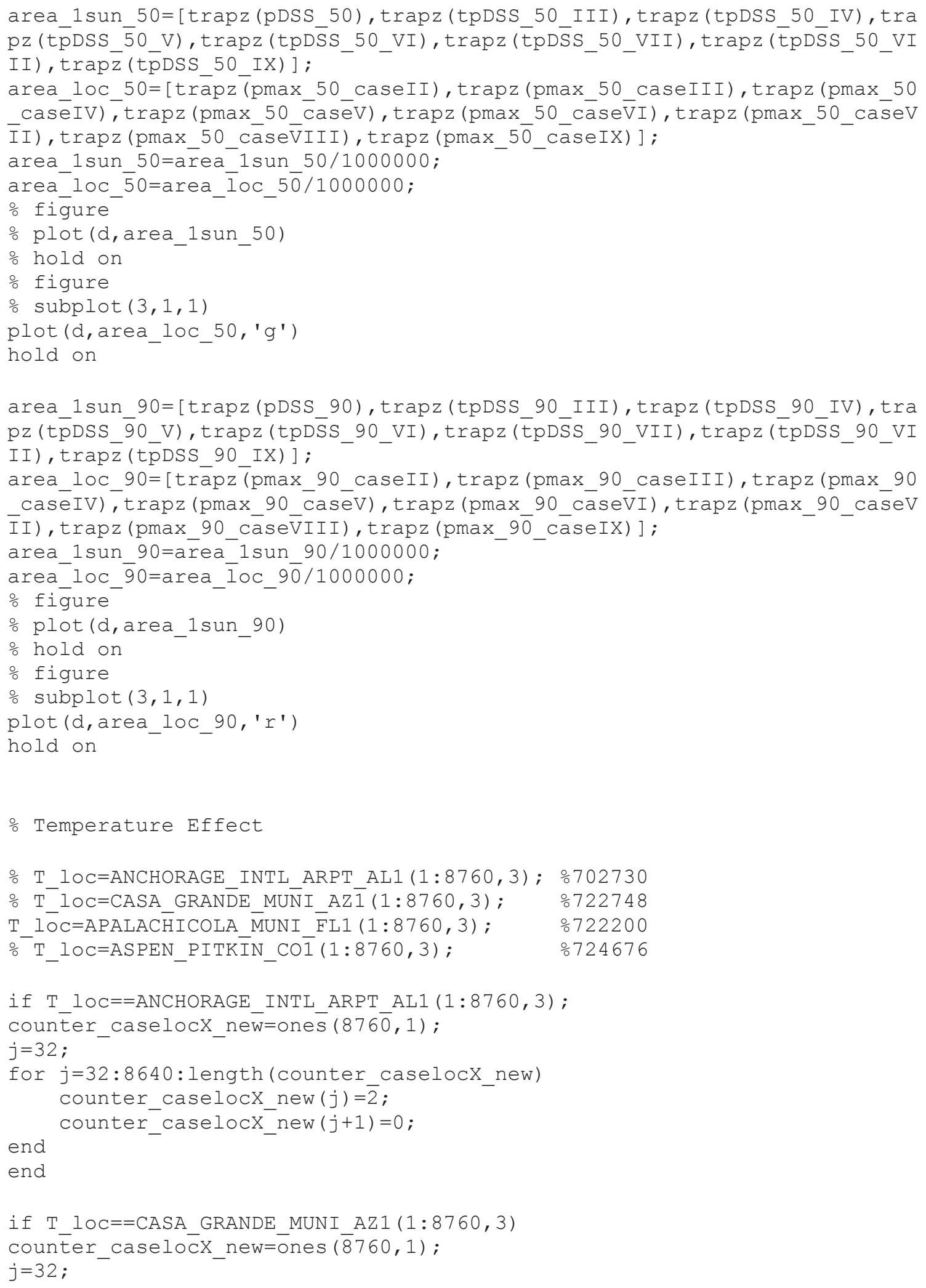




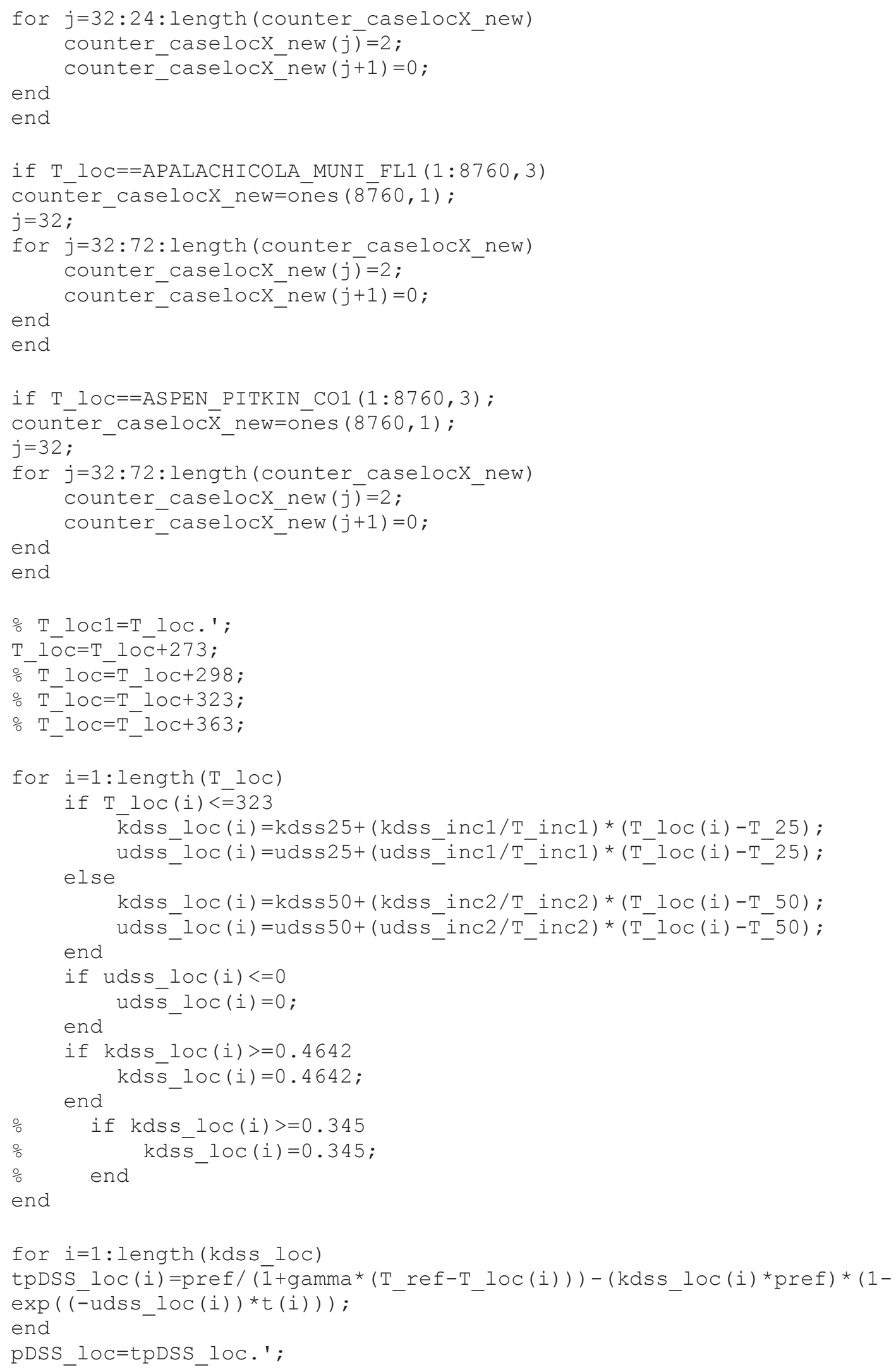




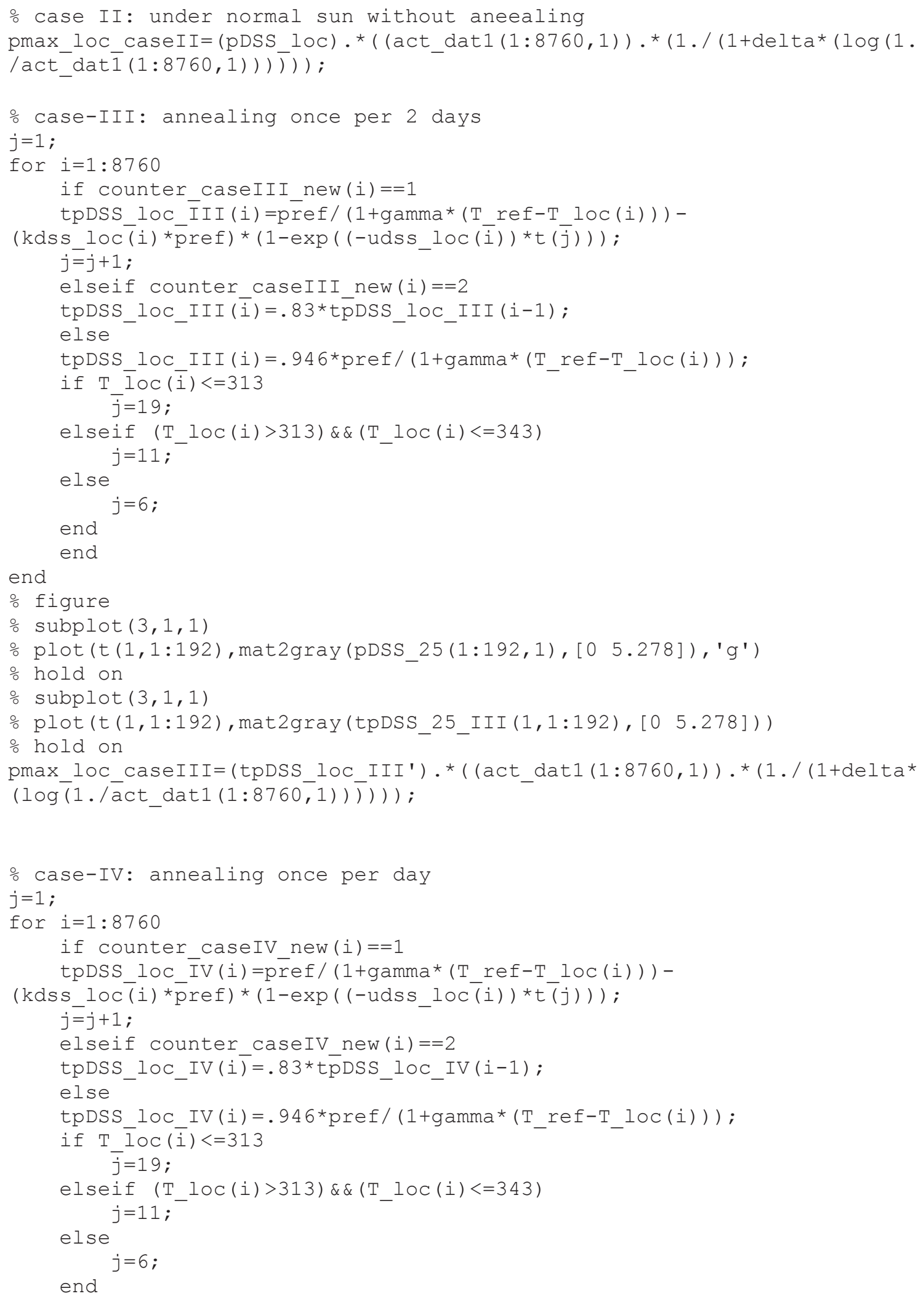




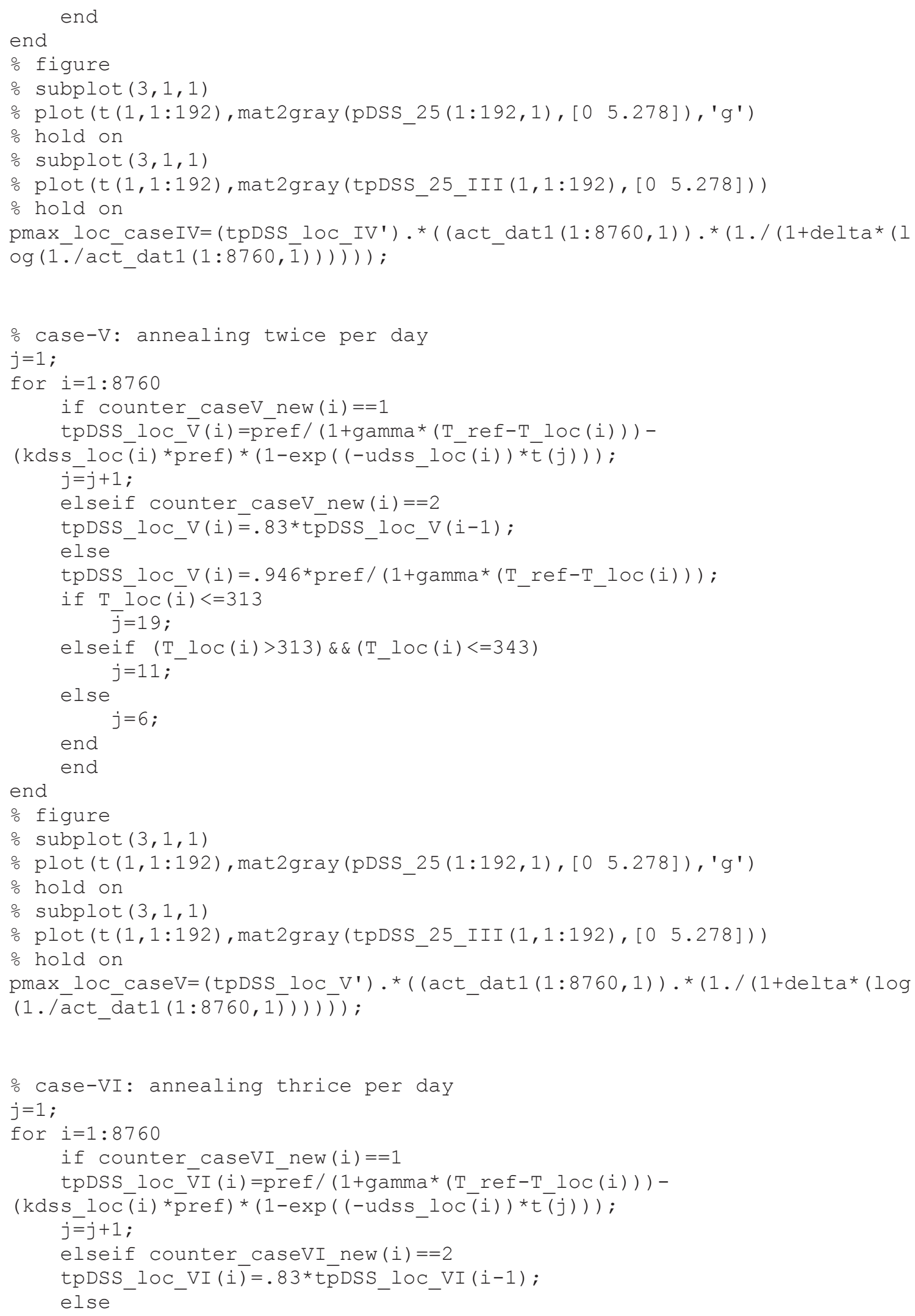




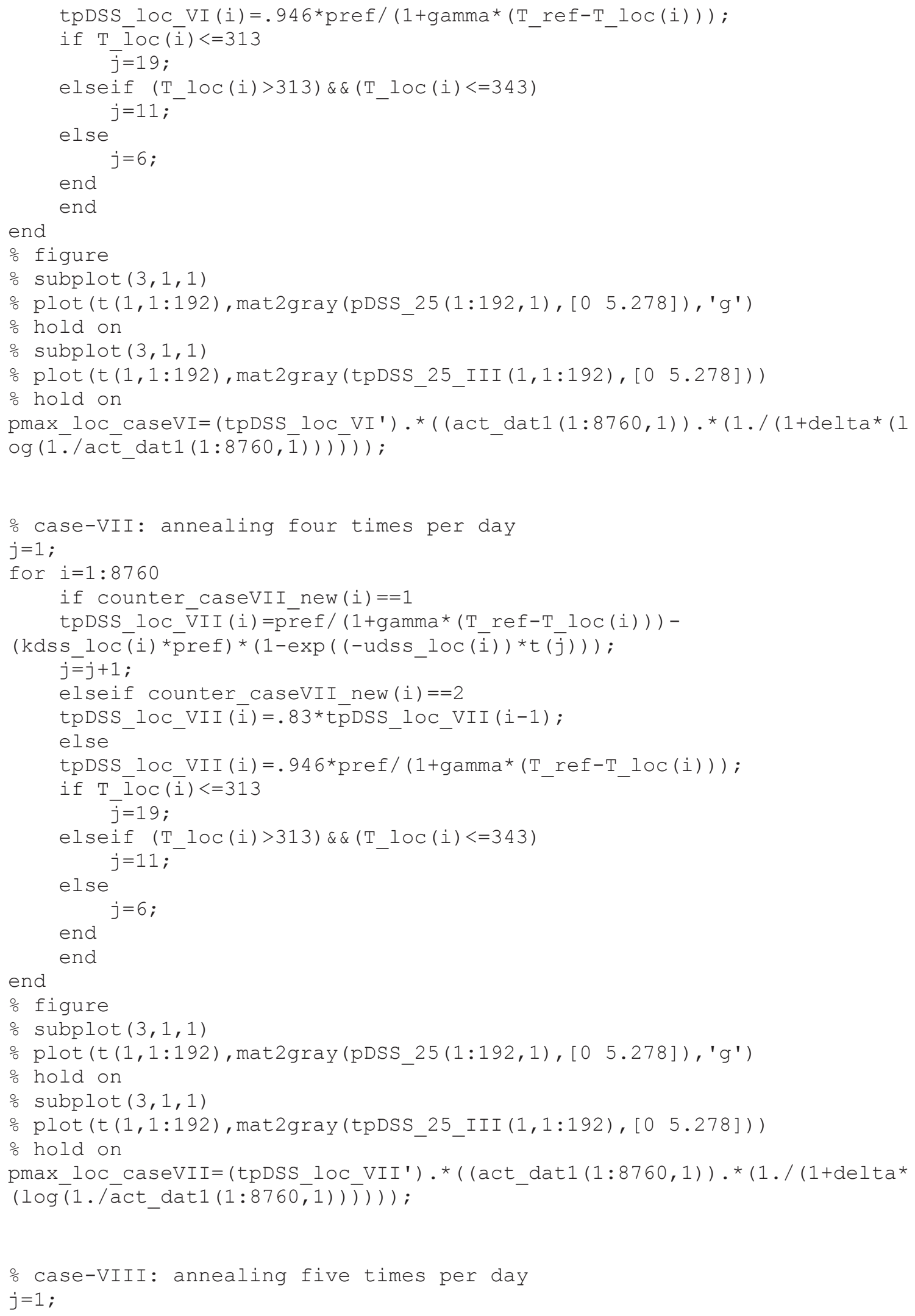




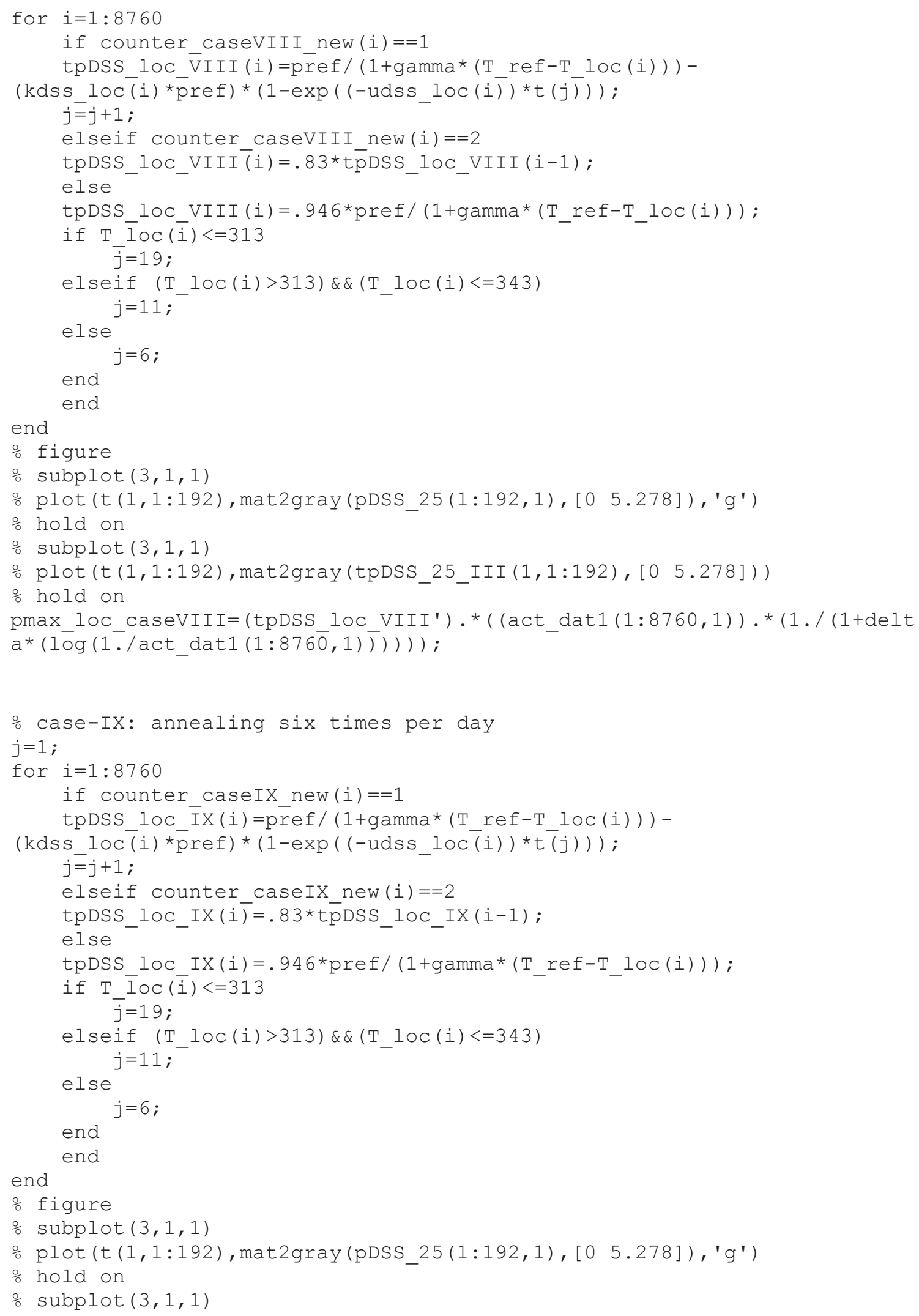




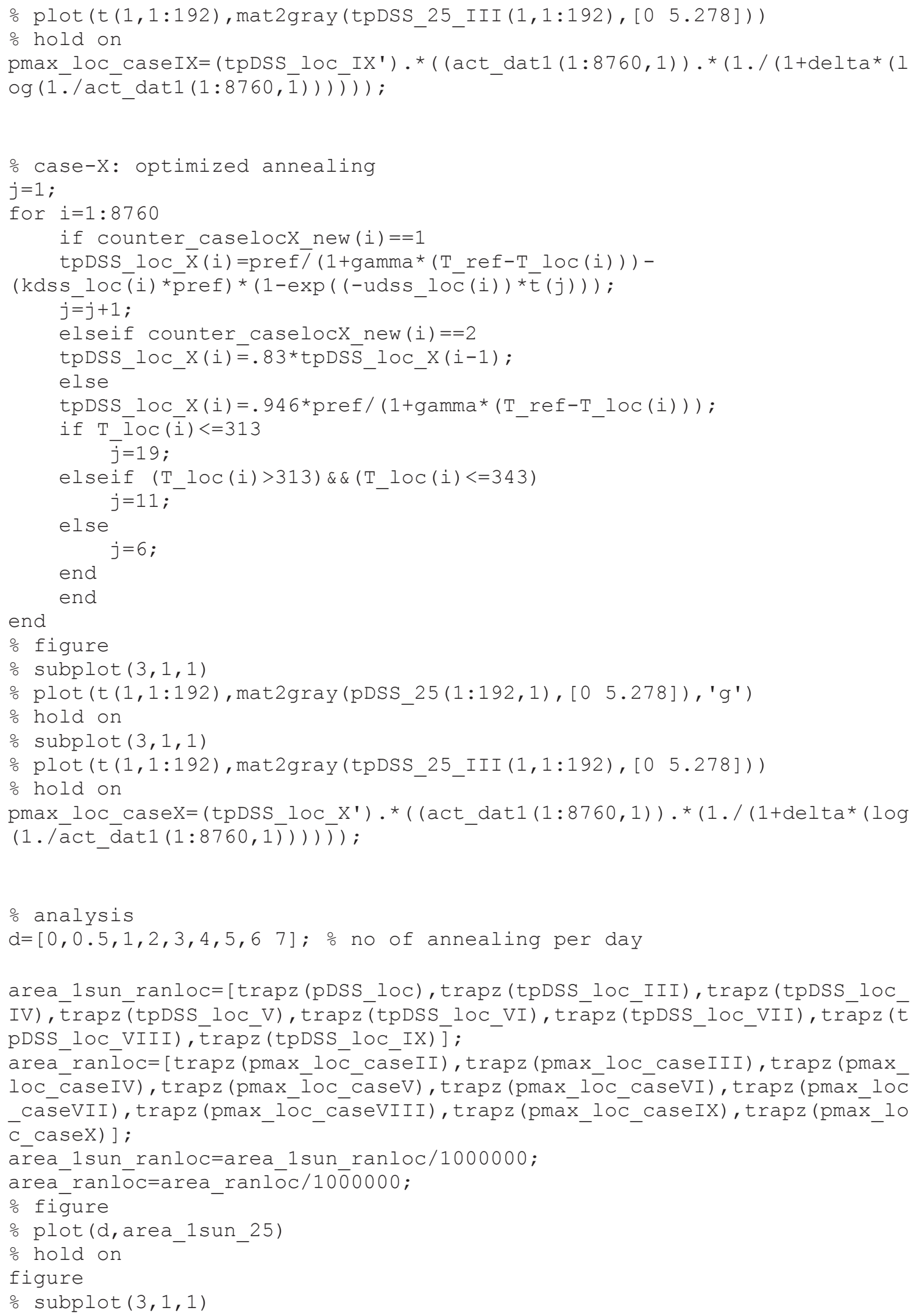


plot (d,area_ranloc, 'k') hold on 